

\section{Disclaimer}

Reference herein to any specific commercial product, process, or service by trade name, trademark, manufacturer, or otherwise, does not necessarily constitute or imply its endorsement, recommendation, or favoring by the United States Government or any agency thereof.

Available for sale to the public from:

U.S. Department of Commerce

National Technical Information Service

5285 Port Royal Road

Springfield, VA 22161-0002

Telephone: (800) 553-6847

Fax: (703) 605-6900

E-mail: orders@ntis.gov

Online ordering: http://www.ntis.gov/help/ordermethods.aspx

Available electronically at http://www.osti.gov/bridge

Available for a processing fee to the U.S. Department of Energy and its contractors, in paper, from:

U.S. Department of Energy

Office of Scientific and Technical Information

P.O. Box 62

Oak Ridge, TN 37831-0062

Telephone: (865) 576-8401

Fax: (865) 576-5728

E-mail: reports@adonis.osti.gov 


\title{
Nevada Test Site Environmental Report 2008 Attachment A: Site Description
}

\author{
Editor: Cathy A. Wills \\ Technical Editor: Sierra Cory \\ Graphic Design/Desktop Publisher Specialist: Elaine Forbes \\ Geographic Information System Specialist: Ashley Burns
}

September 2008

Work Performed Under

Contract No. DE-AC52-06NA25946

Prepared for:

U.S. Department of Energy

National Nuclear Security Administration

Nevada Site Office

Prepared by:

National Security Technologies, LLC

P. O. Box 98521

Las Vegas, NV 89193-8521 


\section{Table of Contents}

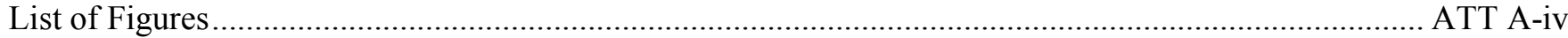

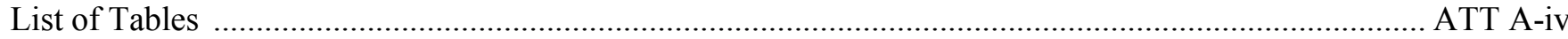

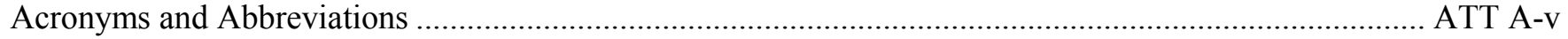

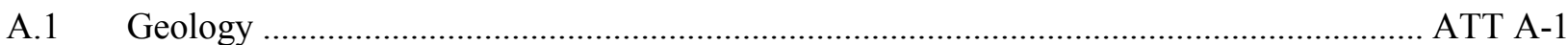

A.1.1 Physiographic/Geologic Setting ........................................................ ATT A-1

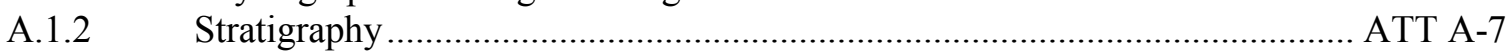

A.1.3 Structural Controls ............................................................................ ATT A-7

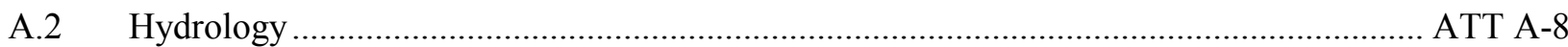

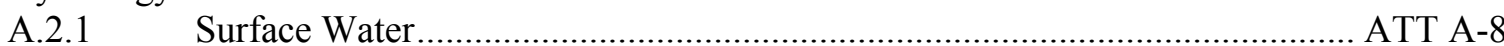

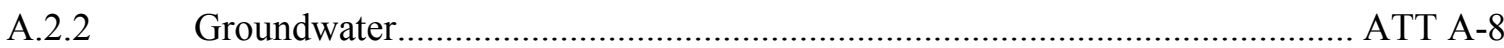

A.2.3 Hydrogeologic Framework for the NTS and Vicinity................................. ATT A-12

A.2.3.1 Hydrogeologic Units........................................................ ATT A-13

A.2.3.2 Hydrostratigraphic Units ...................................................... ATT A-14

A.2.4 General Hydraulic Characteristics of NTS Rocks.................................... ATT A-15

A.2.5 Hydrogeology of the NTS Underground Test Areas.................................... ATT A-16

A.2.5.1 Frenchman Flat Underground Test Area .................................. ATT A-19

A.2.5.2 Yucca Flat/Climax Mine Underground Test Area..................... ATT A-21

A.2.5.3 Pahute Mesa Underground Test Area...................................... ATT A-26

A.2.5.4 Rainier Mesa/Shoshone Mountain......................................... ATT A-31

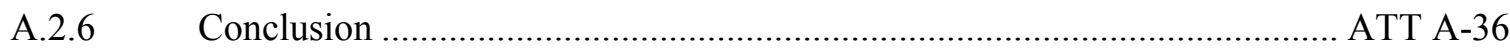

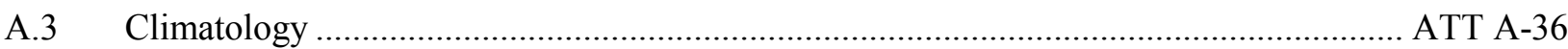

A.3.1 Precipitation ............................................................................ ATT A-36

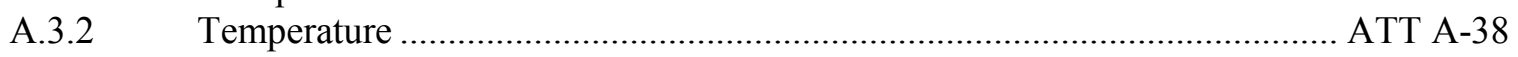

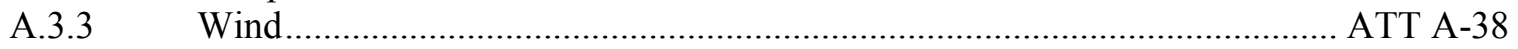

A.3.4 Relative Humidity ................................................................... ATT A-38

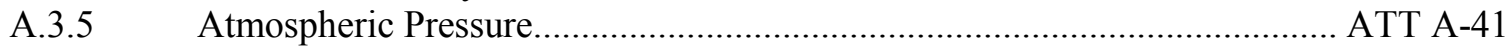

A.3.6 Dispersion Stability Categories........................................................... ATT A-41

A.3.7 Other Natural Phenomena .................................................................. ATT A-41

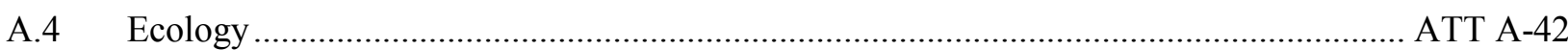

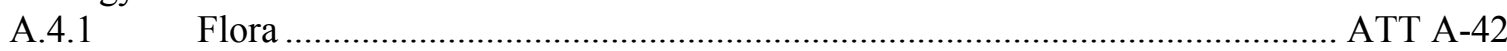

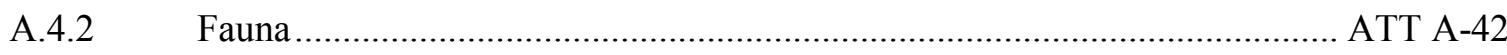

A.4.3 Natural Water Sources …………............................................ ATT A-45

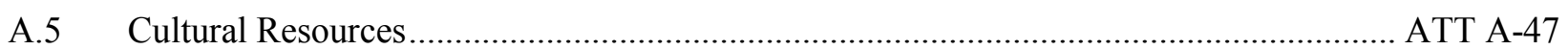

A.5.1 Cultural Resources Investigations on the NTS ....................................... ATT A-47

A.5.2 Paleo-Indian Period............................................................................ ATT A-49

A.5.3 Early Holocene Period ............................................................................ ATT A-49

A.5.4 Middle Holocene Period …….............................................................. ATT A-49

A.5.5 Late Holocene Period ......................................................................... ATT A-49

A.5.6 Ethnohistoric American Indian ...................................................... ATT A-51

A.5.7 Historic Mining on and near the NTS ….................................................. ATT A-52

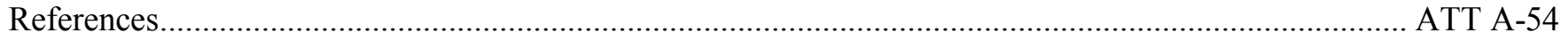




\section{List of Figures}

Figure A-1 Basin and Range Province and Great Basin Province

ATT A-2

Figure A-2 Generalized geologic map of the NTS and vicinity

ATT A-3

Figure A-3

Closed hydrographic subbasins on the NTS

ATT A-9

Figure A-4

Natural springs and seeps on the NTS

ATT A-10

Figure A-5

Groundwater subbasins of the NTS and vicinity.

ATT A-11

Figure A-6

Location of Corrective Action Units and Corrective Action Sites on the NTS.

ATT A-17

Figure A-7

Conceptual east-west cross section through Frenchman Flat

ATT A-20

Figure A-8

Generalized west-east hydrogeologic cross section through central Yucca Flat.

ATT A-23

Figure A-9

Generalized hydrostratigraphic cross section through the Silent Canyon complex.......

ATT A-28

Figure A-10

Generalized hydrostratigraphic cross section through Aqueduct Mesa ......

ATT A-32

Figure A-11

West-east hydrogeologic cross section through Well ER-16-1

ATT A-35

Figure A-12

Mean monthly precipitation at six NTS MEDA stations

ATT A-37

Figure A-13

Temperature extremes and normal maximums and minimums at six

NTS MEDA stations

ATT A-39

Figure A-14

Twenty-year wind rose climatology for the NTS (1984-2004)

ATT A-40

Figure A-15

Distribution of plant alliances on the NTS

ATT A-43

Figure A-16

Figure A-17

Known locations of sensitive plant species on the NTS

ATT A-44

Natural water sources on the NTS.

ATT A-46

Figure A-18

Example of prehistoric petroglyphs found on the NTSThis rock art site is in

Fortymile Canyon

ATT A-47

Figure A-19 DRI archaeologist at an archaeological excavation of a prehistoric site on

Pahute Mesa

ATT A-48

Figure A-20

Building 400, a camera station for photographing atmospheric tests, at Area 6 Control Point

ATT A-48

Figure A-21

Prehistoric projectile points from the NTS (photo by DRI, 1992)

ATT A-50

Brownware bowl recovered from archaeological excavations on Pahute Mesa

ATT A-51

Overview of the Tippipah Spring area

ATT A-52

Figure A-23

Figure A-24

Bower cabin on the NTS ATT A-54

\section{List of Tables}

Table A-1

Table A-2

Table A-3

Table A-4

Table A-5

Table A-6

Table A-7

Table A-8

Table A-9
Quaternary and Tertiary stratigraphic units of the NTS and vicinity

Pre-Tertiary stratigraphic units of the NTS and vicinity

Hydrogeologic units of the NTS area....

Summary of hydrologic properties for hydrogeologic units at the NTS.

Information summary of NTS underground nuclear tests

Hydrostratigraphic units of the Frenchman Flat underground test area

Hydrostratigraphic units of the Yucca Flat underground test area

Hydrostratigraphic units of the Pahute Mesa-Oasis Valley area ....

Hydrostratigraphic units of the Rainier Mesa-Shoshone Mountain area
ATT A-4

ATT A-6

ATT A-13

ATT A-16

ATT A-18

ATT A-20

ATT A-24

ATT A-29

ATT A-33 


\section{Acronyms and Abbreviations}

\begin{tabular}{|c|c|}
\hline AA & alluvial aquifer \\
\hline AEC & Atomic Energy Commission \\
\hline a.k.a. & also known as \\
\hline ATCU & argillic tuff confining unit \\
\hline ATICU & Ammonia Tanks intrusive confining unit \\
\hline $\mathrm{BA}$ & Benham aquifer \\
\hline $\mathrm{BFCU}$ & Bullfrog confining unit \\
\hline BMICU & Black Mountain intrusive confining unit \\
\hline $\mathrm{BN}$ & Bechtel Nevada \\
\hline $\mathrm{BP}$ & before present \\
\hline BRA & Belted Range aquifer \\
\hline BRCU & Belted Range confining unit \\
\hline${ }^{\circ} \mathrm{C}$ & degree Celsius \\
\hline ca. & circa, meaning "approximately" \\
\hline $\mathrm{CA}$ & carbonate aquifer \\
\hline CAS & Corrective Action Site \\
\hline CAU & Corrective Action Unit \\
\hline CCICU & Claim Canyon intrusive confining unit \\
\hline $\mathrm{CCU}$ & clastic confining unit \\
\hline CFCM & Crater Flat composite unit \\
\hline CFCU & Crater Flat confining unit \\
\hline CG & cloud-to-ground \\
\hline $\mathrm{CHCU}$ & Calico Hills confining unit \\
\hline CHICU & Calico Hills intrusive confining unit \\
\hline CHVCM & Calico Hills vitric composite unit \\
\hline CHVTA & Calico Hills vitric-tuff aquifer \\
\hline CHZCM & Calico Hills zeolitized composite unit \\
\hline $\mathrm{cm}$ & centimeter(s) \\
\hline $\mathrm{CP}$ & Control Point \\
\hline DOE & U.S. Department of Energy \\
\hline $\mathrm{DOE} / \mathrm{NV}$ & U.S. Department of Energy, Nevada Operations Office \\
\hline DRI & Desert Research Institute \\
\hline DVCM & detached volcanics composite unit \\
\hline EPA & U.S. Environmental Protection Agency \\
\hline${ }^{\circ} \mathrm{F}$ & degree Fahrenheit \\
\hline $\mathrm{ft}$ & foot or feet \\
\hline FCCM & Fortymile Canyon composite unit \\
\hline FCCU & Fluorspar Canyon confining unit \\
\hline FFACO & Federal Facility Agreement and Consent Order \\
\hline
\end{tabular}


GCU granite confining unit

HGU hydrogeologic unit

HSU hydrostratigraphic unit

in. inch(es)

IA inlet aquifer

IICU intracaldera intrusive confining unit

IT International Technology Corporation

KA Kearsarge aquifer

$\mathrm{km} \quad$ kilometer(s)

kmh kilometer(s) per hour

kt kiloton(s)

LCA lower carbonate aquifer

LCA3 lower carbonate aquifer - upper thrust plate

LCCU lower clastic confining unit

LCCU1 lower clastic confining unit - upper thrust plate

LFA lava-flow aquifer

LPCU lower Paintbrush confining unit

LTCU lower tuff confining unit

LTCU1 lower tuff confining unit 1

LVTA2 lower vitric tuff aquifer 2

LVTA1 lower vitric tuff aquifer 1

LVTA lower vitric tuff aquifer

m meter(s)

$\mathrm{Ma}$ million years ago

$\mathrm{mb} \quad$ millibar(s)

MEDA Meteorological Data Acquisition

MGCU Mesozoic granite confining unit

mi mile(s)

mph miles per hour

NNSA/NSO U.S. Department of Energy, National Nuclear Security Administration Nevada Site Office

NSTec National Security Technologies, LLC

NTS Nevada Test Site

OSBCU Oak Spring Butte confining unit

PBRCM Pre-Belted Range composite unit

PCM Paintbrush composite unit

PCU playa confining unit

PDT Pacific Daylight Time

PLFA Paintbrush lava-flow aquifer

PM-OV Pahute Mesa-Oasis Valley

PST Pacific Standard Time

PVTA Paintbrush vitric-tuff aquifer

RMBCU Rainier Mesa breccia confining unit 


$\begin{array}{ll}\text { RMICU } & \text { Rainier Mesa intrusive confining unit } \\ \text { RM-SM } & \text { Rainier Mesa-Shoshone Mountain } \\ \text { RVICU } & \text { Redrock Valley intrusive confining unit } \\ \text { SCCC } & \text { Silent Canyon caldera complex } \\ \text { SCICU } & \text { Silent Canyon intrusive confining unit } \\ \text { SCVCU } & \text { subcaldera volcanic confining unit } \\ \text { SNJV } & \text { Stoller-Navarro Joint Venture } \\ \text { SWA } & \text { Stockade Wash aquifer } \\ \text { SWL } & \text { static water level } \\ \text { SWNVF } & \text { Southwestern Nevada Volcanic Field } \\ \text { TCU } & \text { tuff confining unit } \\ \text { TCVA } & \text { Thirsty Canyon volcanic aquifer } \\ \text { THCM } & \text { Tannenbaum Hill composit unit } \\ \text { THLFA } & \text { Tannenbaum Hill lava-flow aquifer } \\ \text { TMA } & \text { Timber Mountain aquifer } \\ \text { TMCC } & \text { Timber Mountain caldera complex } \\ \text { TMCM } & \text { Timber Mountain composite unit } \\ \text { TM-LVTA } & \text { Timber Mountain lower vitric-tuff aquifer } \\ \text { TM-UVTA } & \text { Timber Mountain upper vitric-tuff aquifer } \\ \text { TM-WTA } & \text { Timber Mountain welded-tuff aquifer } \\ \text { TPA } & \text { Twin Peaks aquifer } \\ \text { TSA } & \text { Topopah Spring aquifer } \\ \text { TUBA } & \text { Tub Spring aquifer } \\ \text { UCA } & \text { upper carbonate aquifer } \\ \text { UCCU } & \text { upper clastic confining unit } \\ \text { UGTA } & \text { Underground Test Area } \\ \text { UPCU } & \text { upper Paintbrush confining unit } \\ \text { UTCU } & \text { upper tuff confining unit } \\ \text { UTCU1 } & \text { upper tuff confining unit 1 } \\ \text { UTCU2 } & \text { upper tuff confining unit 2 } \\ \text { VCU } & \text { volcaniclastic confining unit } \\ \text { VTA } & \text { vitric-tuff aquifer } \\ \text { WCU } & \text { Wahmonie confining unit } \\ \text { WTA } & \text { welded-tuff aquifer } \\ \text { WVCU } & \text { Wahmonie volcanic confining unit } \\ \text { WWA } & \text { Windy Wash aquifer } \\ \text { YMCHLFA } & \text { Yucca Mountain Calico Hills lava-flow aquifer } \\ \text { YMCFCM } & \text { Yucca Mountain Crater Flat composite unit } \\ \text { YVCM } & \text { younger volcanic composite unit } \\ & \end{array}$





\section{Attachment A: Nevada Test Site Description}

This attachment expands on the general description of the Nevada Test Site (NTS) presented in the Introduction to the Nevada Test Site Environmental Report 2008 (National Security Technologies, LLC [NSTec], 2009a). Included are subsections that summarize the site's geological, hydrological, climatological, and ecological setting. The cultural resources of the NTS are also presented. The subsections are meant to aid the reader in understanding the complex physical and biological environment of the NTS. An adequate knowledge of the site's environment is necessary to assess the environmental impacts of new projects, design and implement environmental monitoring activities for current site operations, and assess the impacts of site operations on the public residing in the vicinity of the NTS. The NTS environment contributes to several key features of the site that afford protection to the inhabitants of adjacent areas from potential exposure to radioactivity or other contaminants resulting from NTS operations. These key features include the general remote location of the NTS, restricted access, extended wind transport times, the great depths to slow-moving groundwater, little or no surface water, and low population density. This attachment complements the annual summary of monitoring program activities and dose assessments presented in the main body of this report.

\section{A.1 Geology}

\section{A.1.1 Physiographic/Geologic Setting}

The NTS is located in the southern part of the Great Basin, the northern-most sub-province of the Basin and Range Physiographic Province (Figure A-1). The NTS terrain is typical of much of the Basin and Range Physiographic Province, characterized by mostly tilted, fault-bounded blocks that are as much as 80 kilometers $(\mathrm{km})(50$ miles [mi]) long and $24 \mathrm{~km}(15 \mathrm{mi})$ wide. These features are modified locally by the Las Vegas Shear Zone (a component of the Walker Lane regional structural belt) in the southern part of the NTS, and by resurgent calderas of the Southwestern Nevada Volcanic Field (SWNVF). The land forms and topography of the NTS area reflect the complex geology and its location in the arid Mojave Desert.

The NTS area is geologically complex, with at least seven Tertiary-age calderas nearby, many relatively young basin-and-range-style normal faults, and Mesozoic-age thrust faults and intrusive bodies, all superimposed on a basement complex of highly deformed Proterozoic- and Paleozoic-age sedimentary and metasedimentary rocks. Geologic units exposed at the surface in the NTS area can be categorized as approximately 40 percent alluviumfilled basins and 20 percent Paleozoic and uppermost Precambrian sedimentary rocks, the remainder being Tertiary-age volcanic rocks with a few intrusive masses (Orkild, 1983; Slate et al., 1999). A generalized geologic map of the NTS area is given in Figure A-2.

The NTS area is dominated by Tertiary-age volcanic rocks formed from materials that were erupted from various vents in the SWNVF, located on and adjacent to the northwestern part of the NTS (Figure A-2). At least seven major calderas have been identified in this multi-caldera silicic volcanic field (Byers et al., 1976; NSTec, 2007). The calderas formed by the voluminous eruption of zoned ash-flow tuffs between 16 and 7.5 million years ago (Ma) (Sawyer et al., 1994). From oldest to youngest, the calderas are Redrock Valley, Grouse Canyon, Area 20, Claim Canyon, Rainier Mesa, Ammonia Tanks, and Black Mountain calderas. A comprehensive review of past studies and the evolution of concepts on calderas of the SWNVF during the period from 1960 to 1988 is presented in Byers et al. (1989).

The volcanic rocks are covered in many areas by a variety of late Tertiary and Quaternary surficial deposits. These younger deposits consist of alluvium, colluvium, eolian (wind-blown sand) deposits, spring deposits, basalt lavas, lacustrine (fresh-water lake) deposits, and playa deposits.

The area includes more than 300 described Tertiary-age volcanic units (Warren et al., 2000a; 2003). As a matter of practicality, some units are grouped together, especially those of limited areal extent or thickness. Table A-1 presents most of the Tertiary volcanic units useful in characterizing the subsurface at the NTS. 


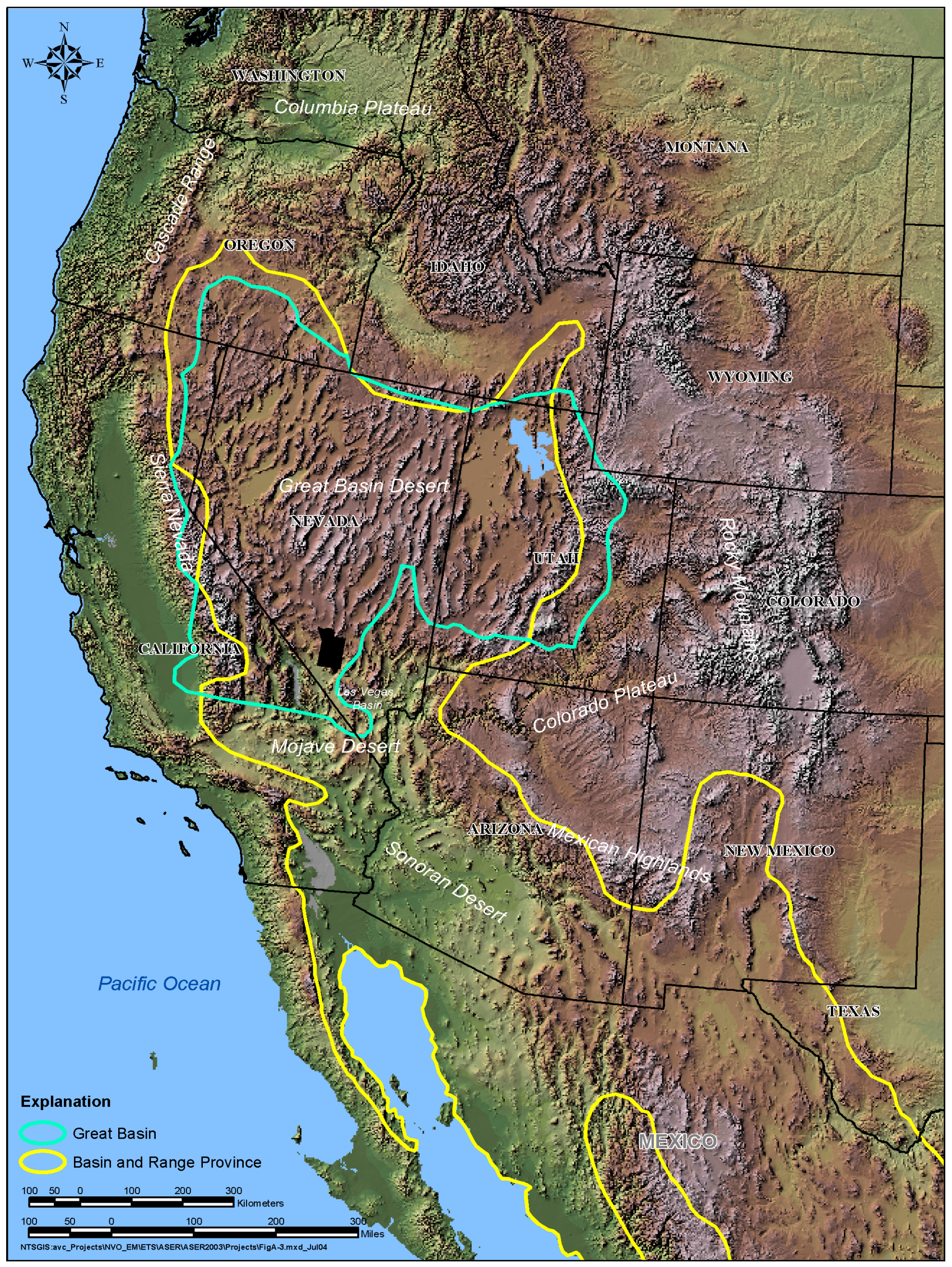

Figure A-1. Basin and Range Province and Great Basin Province (province boundaries from Fiero, 1986) 


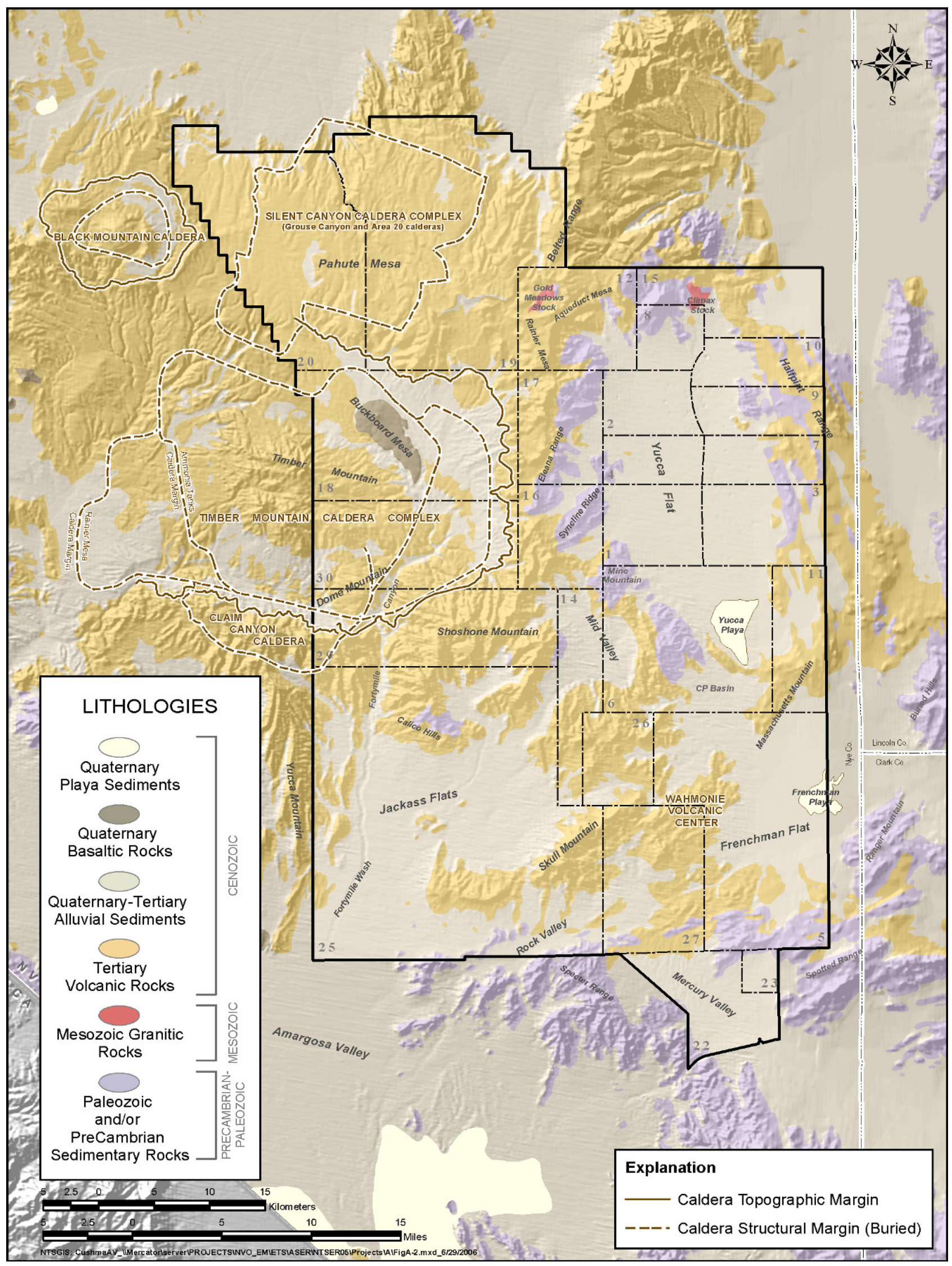

Figure A-2. Generalized geologic map of the NTS and vicinity 
Table A-1. Quaternary and Tertiary stratigraphic units of the NTS and vicinity

\begin{tabular}{|c|c|}
\hline Stratigraphic Assemblages and Major Units ${ }^{(a, b)}$ & Volcanic Sources $^{(\mathrm{c})}$ \\
\hline $\begin{array}{l}\text { Quaternary and Tertiary Sediments } \\
\text { Young alluvium (Qay) } \\
\text { Playa (Qp) } \\
\text { Quaternary - Tertiary colluvium (QTc) } \\
\text { Middle alluvium (Qam) } \\
\text { Eolian sand (QTe) } \\
\text { Quaternary-Tertiary alluvium (QTa) } \\
\text { Quaternary Basalts (Qby) } \\
\text { Pliocene Basalts (Typ) } \\
\text { Tertiary alluvium (Tgy) }\end{array}$ & $\begin{array}{l}\text { Not applicable } \\
\text { Several discrete sources } \\
\text { Several discrete sources } \\
\text { Not applicable }\end{array}$ \\
\hline $\begin{array}{l}\text { Miocene Basalt and Rhyolite } \\
\text { Thirsty Canyon and Younger Basalts (Tyb) } \\
\text { Rhyolite of Obsidian Butte (Tyr) }\end{array}$ & Several discrete sources \\
\hline $\begin{array}{l}\text { Tertiary Sediments } \\
\text { Late synvolcanic sedimentary rocks (Tgm) } \\
\text { Caldera moat-filling sedimentary deposits (Tgc) } \\
\text { Younger landslide and sedimentary breccia (Tgyx) }\end{array}$ & Not applicable \\
\hline $\begin{array}{l}\text { Thirsty Canyon Group (Tt) } \\
\text { Gold Flat Tuff (Ttg) } \\
\text { Trachyte of Hidden Cliff (Tth) } \\
\text { Trachytic rocks of Pillar Spring and Yellow Cleft (Tts) } \\
\text { Trail Ridge Tuff (Ttt) } \\
\text { Pahute Mesa and Rocket Wash Tuffs (Ttp) } \\
\text { Comendite of Ribbon Cliff (Ttc) }\end{array}$ & Black Mountain Caldera (9.4 Ma) \\
\hline $\begin{array}{l}\text { Volcanics of Fortymile Canyon (Tf) } \\
\text { Rhyolite of Boundary Butte (Tfu) } \\
\text { Post-Timber Mountain Basaltic Rocks (Tft) } \\
\text { Trachyte of Donovan Mountain (Tfn) } \\
\text { Rhyolite of Shoshone Mountain (Tfs) } \\
\text { Lavas of Dome Mountain (Tfd) } \\
\text { Younger intrusive rocks (Tiy) } \\
\text { Rhyolite of Rainbow Mountain (Tfr) } \\
\text { Beatty Wash Formation (Tfb) } \\
\text { Tuff of Leadfield Road (Tfl) } \\
\text { Rhyolite of Fleur-de-lis Ranch (Tff) }\end{array}$ & $\begin{array}{c}\text { Several discrete vent areas in and around the Timber } \\
\text { Mountain Caldera Complex }\end{array}$ \\
\hline $\begin{array}{l}\text { Timber Mountain Group (Tm) } \\
\text { Trachyte of East Cat Canyon (Tmay) } \\
\text { Tuff of Buttonhook Wash (Tmaw) } \\
\text { Ammonia Tanks Tuff (Tma) } \\
\text { Bedded Ammonia Tanks Tuff (Tmab) } \\
\text { Timber Mountain landslide breccia (Tmx) } \\
\text { Rhyolite of Tannenbaum Hill (Tmat) } \\
\text { Basalt of Tierra (Tmt) } \\
\text { Rainier Mesa Tuff (Tmr) } \\
\text { Rhyolite of Fluorspur Canyon (Tmrf) } \\
\text { Tuff of Holmes Road (Tmrh) } \\
\text { Landslide or eruptive breccia (Tmrx) } \\
\text { Rhyolite of Windy Wash (Tmw) } \\
\text { Transitional Timber Mountain rhyolites (Tmn) }\end{array}$ & $\begin{array}{l}\text { Timber Mountain Caldera Complex: } \\
\text { Ammonia Tanks Caldera (11.45 Ma) } \\
\text { Rainier Mesa Caldera (11.6 Ma) }\end{array}$ \\
\hline
\end{tabular}


Table A-1. Quaternary and Tertiary stratigraphic units of the NTS and vicinity (continued)

\begin{tabular}{|c|c|}
\hline Stratigraphic Assemblages and Major Units ${ }^{(a, b)}$ & Volcanic Sources $^{(c)}$ \\
\hline $\begin{array}{l}\text { Paintbrush Group (Tp) } \\
\text { Rhyolite of Benham (Tpb) } \\
\text { Post-Tiva Canyon rhyolites (Tpu) } \\
\text { Rhyolite of Scrugham Peak (Tps) } \\
\text { Paintbrush caldera-collapse breccias (Tpx) } \\
\text { Tiva Canyon Tuff (Tpc) } \\
\text { Yucca Mountain Tuff (Tpy) } \\
\text { Rhyolite of Delirium Canyon (Tpd) } \\
\text { Rhyolite of Echo Peak (Tpe) } \\
\text { Middle Paintbrush Group rhyolites (Tpm) } \\
\text { Pah Canyon Tuff (Tpp) } \\
\text { Rhyolite of Silent Canyon (Tpr) } \\
\text { Topopah Spring Tuff (Tpt) } \\
\text { Calico Hills Formation (Th; formerly Tac) }\end{array}$ & Claim Canyon Caldera (12.65 Ma) \\
\hline Wahmonie Formation (Tw) & Wahmonie Volcanic Center \\
\hline $\begin{array}{l}\text { Crater Flat Group (Tc) } \\
\text { Rhyolite of Inlet (Tci) } \\
\text { Prow Pass Tuff (Tcp) } \\
\text { Rhyolite of Kearsarage (Tcpk) } \\
\text { Andesite of Grimy Gulch (Tcg) } \\
\text { Bullfrog Tuff (Tcb) } \\
\text { Rhyolites in the Crater Flat Group (Tcr) } \\
\text { Tram Tuff (Tct) } \\
\text { Belted Range Group (Tb) } \\
\text { Deadhorse Flat Formation (Tbd) } \\
\text { Grouse Canyon Tuff (Tbg) } \\
\text { Comendite of Split Range (Tbgs) } \\
\text { Comendite of Quartet Dome (Tbq) }\end{array}$ & $\begin{array}{l}\text { Silent Canyon Caldera Complex: } \\
\text { Area } 20 \text { Caldera (13.1 Ma) } \\
\text { Grouse Canyon Caldera (13.6 Ma) }\end{array}$ \\
\hline $\begin{array}{l}\text { Tram Ridge Group (Tr) } \\
\text { Lithic Ridge Tuff (Trl) } \\
\text { Dikes of Tram Ridge (Trd) } \\
\text { Rhyolite of Picture Rock (Trr) }\end{array}$ & Uncertain \\
\hline $\begin{array}{l}\text { Tunnel Formation }(\operatorname{Tn}) \\
\text { Tunnel } 4 \text { Member }(\operatorname{Tn} 4) \\
\text { Tunnel } 3 \text { Member }(\operatorname{Tn} 3) \\
\end{array}$ & Uncertain \\
\hline $\begin{array}{l}\text { Volcanics of Quartz Mountain (Tq) } \\
\text { Tuff of Sleeping Butte (Tqs) } \\
\text { Hornblende-bearing rhyolite of Quartz Mountain(Tqh) } \\
\text { Tuff of Tolicha Peak (Tqt) } \\
\text { Early rhyolite of Quartz Mountain (Tqe) } \\
\text { Dacite of Mount Helen (Tqm) }\end{array}$ & Uncertain \\
\hline $\begin{array}{l}\text { Volcanics of Big Dome (Tu) } \\
\text { Comendite of Ochre Ridge (Tuo) } \\
\text { Tub Spring Tuff (Tub) } \\
\text { Comendite of Emigrant Valley (Tue) }\end{array}$ & Unknown (14.9 Ma) \\
\hline
\end{tabular}


Table A-1. Quaternary and Tertiary stratigraphic units of the NTS and vicinity (continued)

\begin{tabular}{|c|c|}
\hline Stratigraphic Assemblages and Major Units ${ }^{(a, b)}$ & Volcanic Sources $^{(\mathrm{c})}$ \\
\hline $\begin{array}{l}\text { Volcanics of Oak Spring Butte (To) } \\
\text { Tunnel bed } 2 \text { (Ton2) } \\
\text { Yucca Flat Tuff (Toy) } \\
\text { Tunnel bed } 1 \text { (Ton1) } \\
\text { Redrock Valley Tuff (Tor) } \\
\text { Tuff of Twin Peaks (Tot) }\end{array}$ & $\begin{array}{c}\text { Redrock Valley Caldera (15.4 Ma) } \\
\text { Unknown (15.5 Ma) }\end{array}$ \\
\hline Older Volcanics (Tqo) & Unknown \\
\hline Paleocolluvium ( $\mathrm{Tl}$ ) & Not applicable \\
\hline
\end{tabular}

(a) Compiled from Slate et al. (1999) and Ferguson et al. (1994).

(b) Letters in parentheses are stratigraphic unit map symbols.

(c) Sources and ages, where known, from Sawyer et al. (1994). Redrock Valley Caldera, NSTec (2007).

Refer to Table A-2 for lists of Mesozoic, Paleozoic, and Precambrian sedimentary rock formations.

Underlying the Tertiary volcanic rocks are Paleozoic and Proterozoic sedimentary rocks including dolomite, limestone, quartzite, and argillite, some of which form the primary regional aquifer and the regional hydrologic "basement" (Table A-2). During Precambrian and Paleozoic time, as much as 10,000 meters (m) $(32,800$ feet [ft]) of marine sediments were deposited in the NTS region (Cole, 1997). The only surface exposure of Mesozoic-age rocks in the NTS area are granitic intrusive masses, the Gold Meadows Stock north of Rainier Mesa (Gibbons et al., 1963; Snyder, 1977), and the Climax Stock located at the extreme north end of Yucca Flat (Barnes et al., 1963; Maldonado, 1977) (Figure A-2).

Table A-2. Pre-Tertiary stratigraphic units of the NTS and vicinity

\begin{tabular}{|c|c|c|c|c|}
\hline Map Unit & $\begin{array}{c}\text { Stratigraphic Unit } \\
\text { Map Symbol }\end{array}$ & $\begin{array}{r}\text { Stratigr } \\
\text { Feet }\end{array}$ & $\begin{array}{l}\text { Thickness } \\
\text { Meters }\end{array}$ & Dominant Lithology \\
\hline $\begin{array}{l}\text { Gold Meadows Stock } \\
\text { Climax Stock }\end{array}$ & $\begin{array}{l}\mathrm{Kgg} \\
\mathrm{Kgc}\end{array}$ & N/A & N/A & $\begin{array}{l}\text { Quartz monzonite } \\
\text { Granodiorite }\end{array}$ \\
\hline $\begin{array}{l}\text { Tippipah Limestone (correlative } \\
\text { with the Bird Spring Formation) }\end{array}$ & $\mathrm{PPt}$ & 3,500 & 1,070 & Limestone \\
\hline $\begin{array}{l}\text { Chainman Shale and Eleana } \\
\text { Formation }\end{array}$ & $\begin{array}{l}\mathrm{Mc} \\
\mathrm{MDe}\end{array}$ & 4,000 & 1,220 & Shale, argillite, and quartzite \\
\hline $\begin{array}{l}\text { Guilmette Formation } \\
\text { Simonson Dolomite } \\
\text { Sevy Dolomite } \\
\text { Laketown Dolomite } \\
\text { Ely Spring Dolomite } \\
\text { Eureka Quartzite } \\
\text { Antelope Valley Limestone } \\
\text { Ninemile Formation } \\
\text { Goodwin Limestone } \\
\text { Nopah Formation } \\
\text { Bonanza King Formation } \\
\text { Carrara Formation (upper) }\end{array}$ & $\begin{array}{l}\mathrm{Dg} \\
\mathrm{Ds} \\
\mathrm{DSs} \\
\mathrm{Sl} \\
\mathrm{Oes} \\
\mathrm{Oe} \\
\mathrm{Oa} \\
\mathrm{On} \\
\mathrm{Og} \\
\mathrm{Cn} \\
\mathrm{Cb} \\
\mathrm{Cc}\end{array}$ & $\begin{array}{c}1,400 \\
1,100 \\
690 \\
650 \\
340 \\
400 \\
1,530 \\
335 \\
685 \\
2,050 \\
4,350 \\
925\end{array}$ & $\begin{array}{l}430 \\
330 \\
210 \\
200 \\
105 \\
125 \\
466 \\
102 \\
209 \\
620 \\
1,330 \\
280\end{array}$ & $\begin{array}{l}\text { Limestone } \\
\text { Dolomite } \\
\text { Dolomite } \\
\text { Dolomite } \\
\text { Dolomite } \\
\text { Quartzite } \\
\text { Limestone } \\
\text { Limestone } \\
\text { Limestone } \\
\text { Limestone } \\
\text { Limestone/dolomite } \\
\text { Limestone }\end{array}$ \\
\hline $\begin{array}{l}\text { Carrara Formation (lower) } \\
\text { Zabriskie Quartzite } \\
\text { Wood Canyon Formation } \\
\text { Stirling Quartzite } \\
\text { Johnnie Formation }\end{array}$ & $\begin{array}{c}\mathrm{Cc} \\
\mathrm{Cz} \\
\mathrm{CZw} \\
\mathrm{Zs} \\
\mathrm{Zj}\end{array}$ & $\begin{array}{c}925 \\
200 \\
2,300 \\
2,900 \\
3,000\end{array}$ & $\begin{array}{c}280 \\
60 \\
700 \\
890 \\
914\end{array}$ & $\begin{array}{l}\text { Shale/Siltstone } \\
\text { Quartzite } \\
\text { Micaceous quartzite } \\
\text { Quartzite } \\
\text { Quartzite/siltstone/limestone }\end{array}$ \\
\hline
\end{tabular}

(Stratigraphic units and lithologies adapted from Cole, 1992) 


\section{A.1.2 Stratigraphy}

In order to confidently characterize the geology at the NTS, geoscientists must start from a well understood stratigraphic system. Refinement of the stratigraphy of the area was a continuous process during the decades in which geoscientists associated with the Weapons Testing Program worked to understand the complex volcanic setting (documented by Byers et al., 1989). The need to develop detailed geologic models in support of the Underground Test Area (UGTA) Sub-Project (see Chapter 14 of the main body of this document) intensified this process, and the recognition of smaller and smaller distinct volcanic units permitted a greater understanding of the three-dimensional configuration of the various types of rocks, which has been incorporated into the geologic framework. Efforts to understand the structure and stratigraphy of the non-volcanic rocks (pre-Tertiary) have also continued to a lesser degree (Cashman and Trexler, 1991; Cole, 1997; Cole and Cashman, 1999; Trexler et al., 2003). The most widespread and significant Quaternary and Tertiary (mainly volcanic) units of the NTS area are listed in Table A-1. Refer to Table A-2 for a list of Mesozoic (granitic), Paleozoic (sedimentary), and Precambrian (sedimentary and metamorphic) stratigraphic units.

\section{A.1.3 Structural Controls}

Geologic structures are an important component of the hydrogeology of the area. Structures define the geometric configuration of the area, including the distribution, thickness, and orientation of units. Synvolcanic structures, including caldera faults and some normal faults had strong influence on depositional patterns of many of the units. The juxtaposition of units with different hydrologic properties across faults may have significant hydrogeologic consequences. Also, faults may act as either conduits or barriers of groundwater flow, depending on the difference in permeability between a fault zone and the surrounding rocks and their orientation within the present stress field. This is partially determined by whether the fault zone is characterized by open fractures, or if it is associated with fine-grained gouge or increased alteration.

Five main types of structural features exist in the area:

- Thrust faults (e.g., Belted Range and Control Point [CP] thrusts)

- Normal faults (e.g., Yucca and West Greeley faults)

- Transverse faults and structural zones (e.g., Rock Valley and Cane Spring faults)

- Calderas (e.g., Timber Mountain and Silent Canyon caldera complexes)

- Detachment faults (e.g., Fluorspar Canyon - Bullfrog Hills detachment fault)

The Belted Range thrust fault is the principal pre-Tertiary structure in the NTS region and, thus, controls the distribution of pre-Tertiary rocks in the area. The fault can be traced or inferred from Bare Mountain just south of the southwest corner of the NTS area to the northern Belted Range, just north of the NTS, a distance of more than $130 \mathrm{~km}(81 \mathrm{mi})$. It is an eastward-directed thrust fault that generally places late Proterozoic to early Cambrian rocks over rocks as young as Mississippian. Several imbricate thrust faults occur east of the main thrust fault. Deformation related to the Belted Range thrust fault occurred sometime between 100 and $250 \mathrm{Ma}$. Lesser thrusts of similar age are mapped in the area (e.g., the CP and Spotted Range thrusts).

Normal faults in the area are related mainly to basin-and-range extension (e.g., Yucca fault in Yucca Flat and West Greeley fault on Pahute Mesa). Most of them likely developed during and after the main phase of volcanic activity of the SWNVF (Sawyer et al., 1994). The majority of these faults are northwest- to northeast-striking, high-angle faults. However, the exact locations, amount of offset along the faults, and character of the faults become increasingly uncertain with depth.

Calderas are probably the most hydrogeologically important features in the NTS area. Volcano-tectonic and geomorphic processes related to caldera development result in abrupt and dramatic lithologic and thickness changes across caldera margins. Consequently, caldera margins (i.e., faults) separate regions with considerably different hydrogeologic character. 


\section{A.2 Hydrology}

The hydrologic character of the NTS and vicinity reflects the region's arid climatic conditions and complex geology (D'Agnese et al., 1997). The hydrology of the NTS has been extensively studied for over 50 years (U.S. Department of Energy [DOE], 1996); numerous scientific reports and large databases are available (refer to cited references for more detailed information). The following subsections present an overview of the hydrologic setting of the NTS and vicinity, including summary descriptions of surface water and groundwater, hydrogeologic framework, and brief descriptions of the hydrogeology for each of the idle underground test areas on the NTS. The reader is directed to Chapter 14 in the main body of this document for a discussion of the hydrogeologic modeling efforts conducted through the UGTA Sub-Project.

\section{A.2.1 Surface Water}

The NTS is located within the Great Basin, a closed hydrographic province that comprises several closed hydrographic basins (Figure A-3). The closed hydrographic basins of the NTS (most notably Yucca and Frenchman Flats) are subbasins of the Great Basin. Streams in the region are ephemeral, flowing only in response to precipitation events or snowmelt. Runoff is conveyed through normally dry washes toward the lowest areas of the closed hydrographic subbasins, and collects on playas. There are two playas (seasonally dry lakes) on the NTS: Frenchman Lake and Yucca Lake, which lie in Frenchman and Yucca Flats, respectively. While water may stand on the playas for a few weeks before evaporating, the playas are dry most of the year. Surface water may leave the NTS in only a few places, such as Fortymile Canyon in the southwestern NTS.

Springs that emanate from local perched groundwater systems are the only natural sources of perennial surface water in the region. There are 24 known springs or seeps on the NTS (Hansen et al., 1997; Bechtel Nevada [BN], 1999) (Figure A-4). Spring discharge rates are low, ranging from 0.014 to 2.2 liters/second (0.22 to 35 gallons/minute) (International Technology Corporation [IT], 1997). Most water discharged from springs travels only a short distance from the source before evaporating or infiltrating into the ground. The springs are important sources of water for wildlife, but they are too small to be of use as a public water supply source.

Other surface waters on the NTS include man-made impoundments constructed at several locations throughout the NTS to support various operations. These are numerous and include open industrial reservoirs, containment ponds, and sewage lagoons. Surface water is not a source of drinking water on the NTS.

\section{A.2.2 Groundwater}

The NTS is located within the Death Valley regional groundwater flow system, one of the major hydrologic subdivisions of the southern Great Basin (Waddell et al., 1984; Laczniak et al., 1996). Groundwater in southern Nevada is conveyed within several flow-system subbasins in the Death Valley regional flow system (a subbasin is defined as the area that contributes water to a major surface discharge area [Laczniak, et al., 1996]). Three principal groundwater subbasins, named for their down-gradient discharge areas, have been identified within the NTS region: the Ash Meadows, Oasis Valley, and Alkali Flat-Furnace Creek Ranch subbasins (Waddell et al., 1984) (Figure A-5).

The groundwater-bearing rocks at the NTS have been classified into several hydrogeologic units (HGUs) (see Section A.2.3), of which the most important is the lower carbonate aquifer, a thick sequence of Paleozoic carbonate rock. This unit extends throughout the subsurface of central and southeastern Nevada, and is considered to be a regional aquifer (Winograd and Thordarson, 1975; Laczniak et al., 1996; IT, 1996a). Various volcanic and alluvial aquifers are also locally important as water sources. 


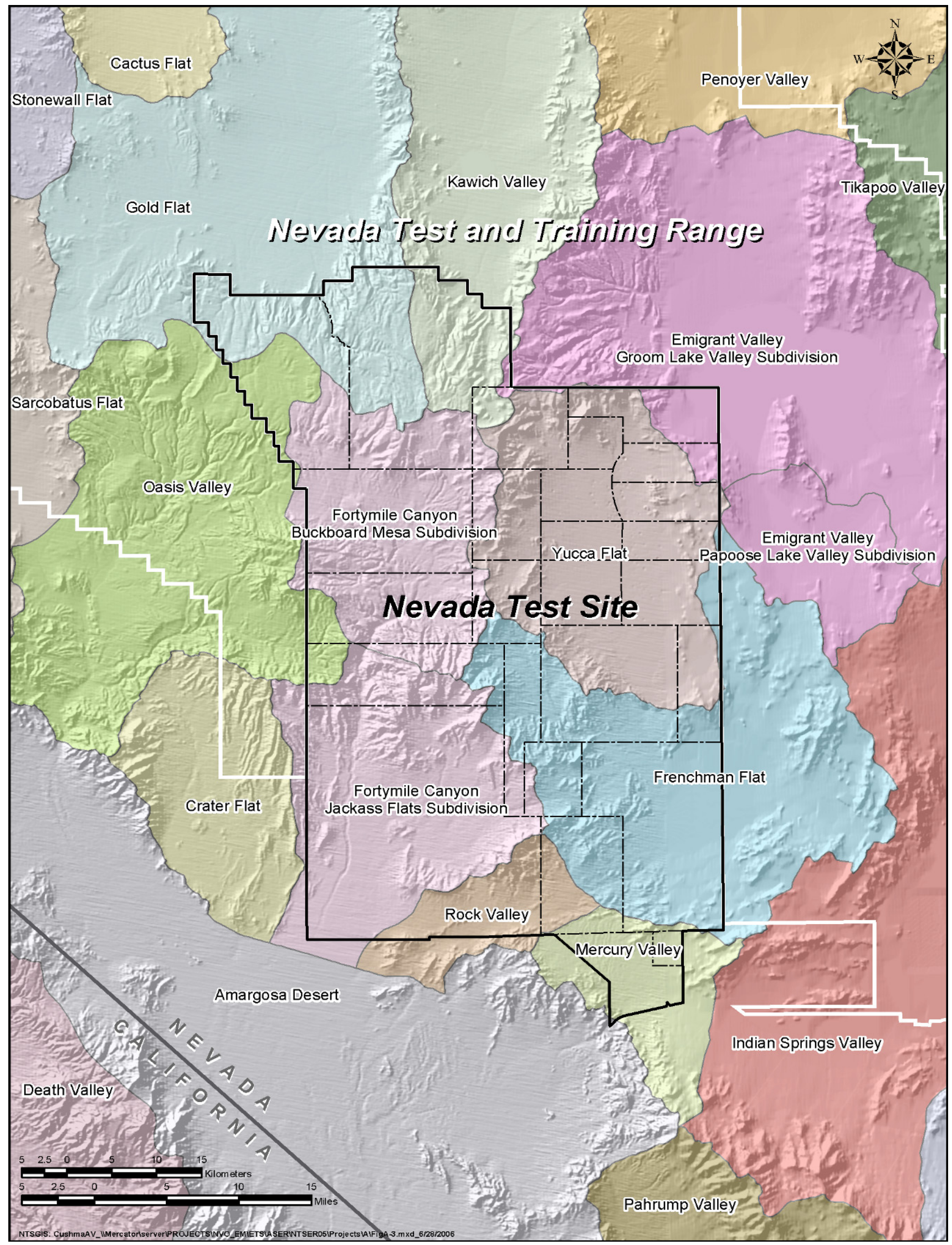

Figure A-3. Closed hydrographic subbasins on the NTS (from State of Nevada Engineers Office, 1974) 


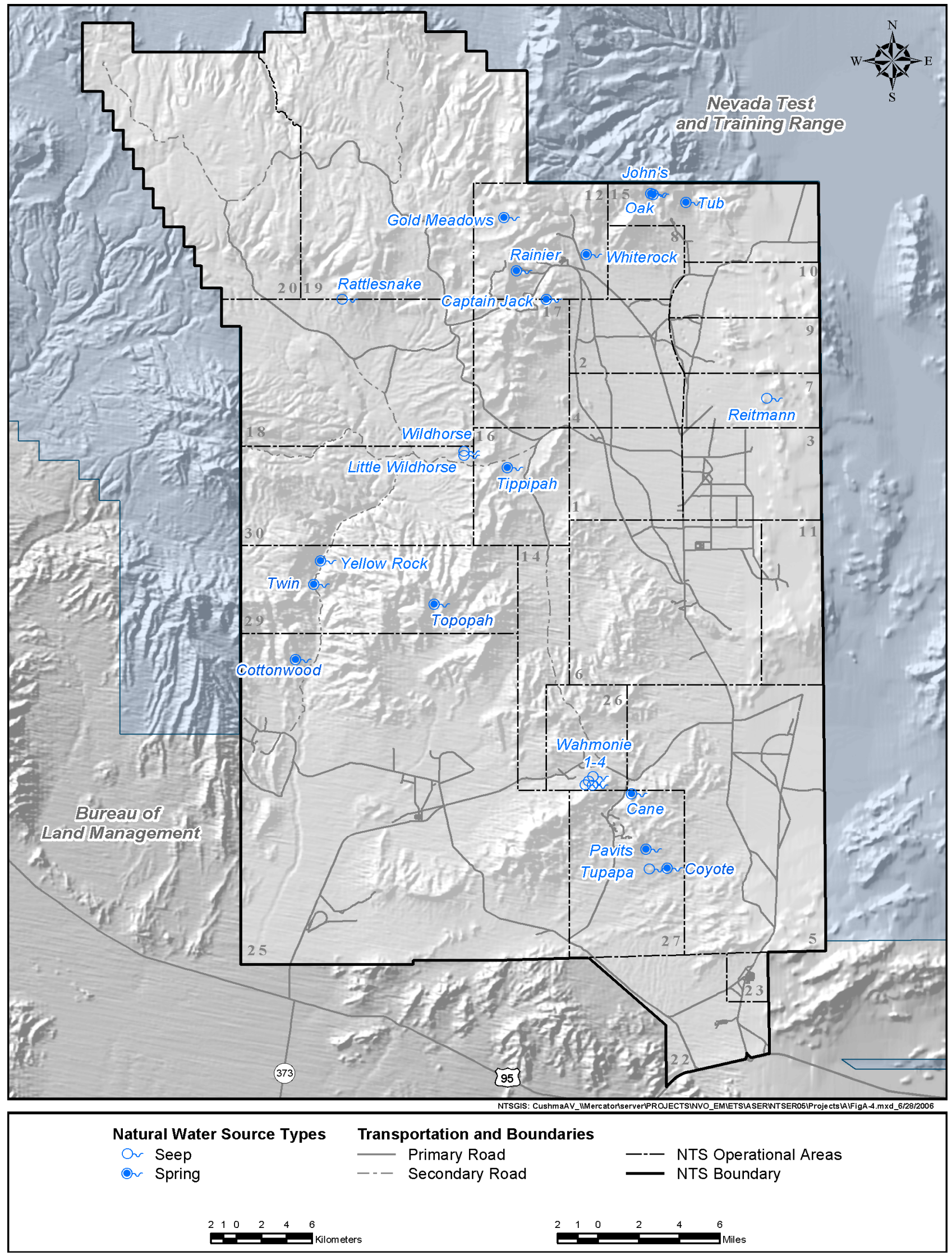

Figure A-4. Natural springs and seeps on the NTS (from Hansen et al., 1997; BN, 1999) 


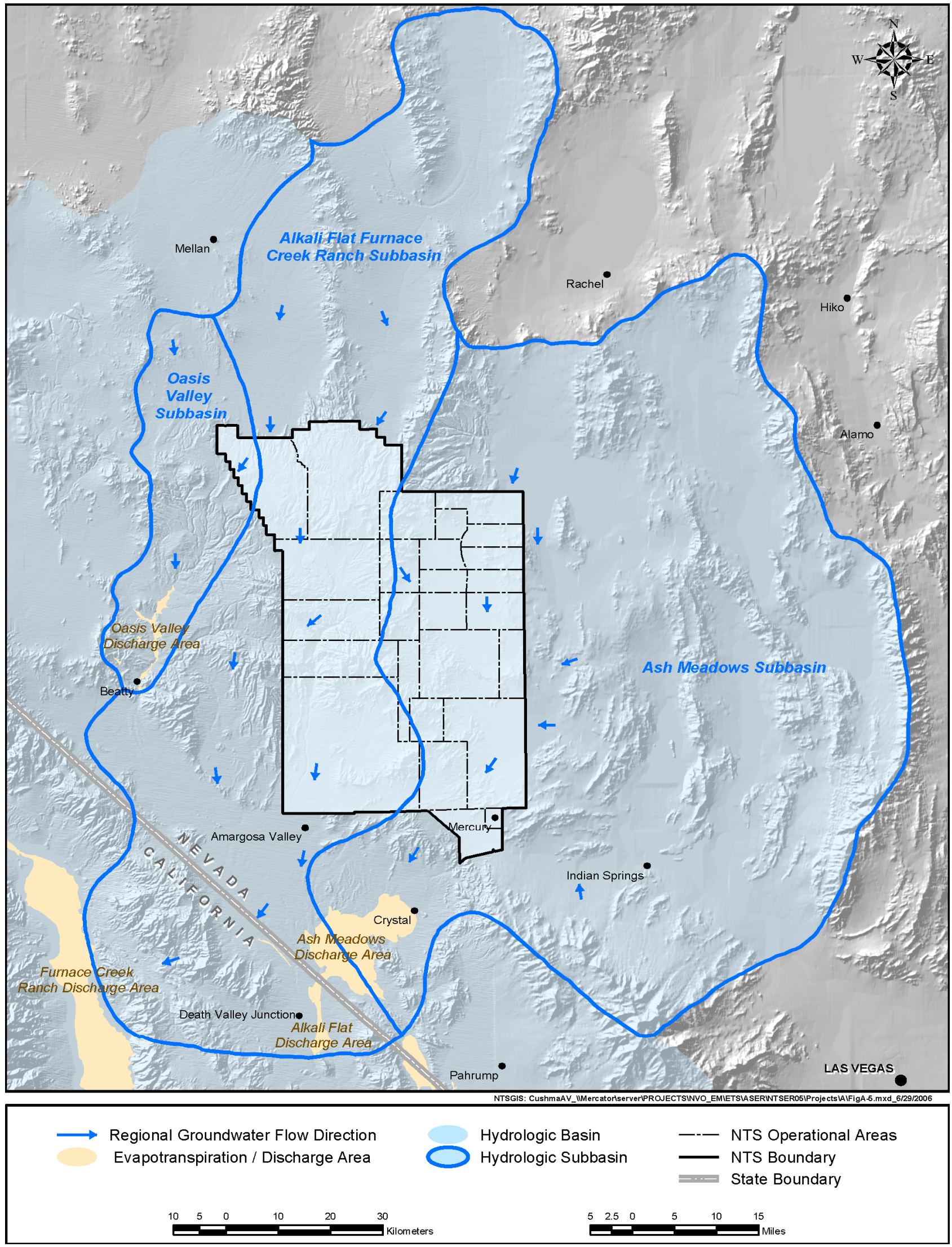

Figure A-5. Groundwater subbasins of the NTS and vicinity (modified from Waddell et al., 1984; Laczniak et al., 1996; and Laczniak et al., 2001) 
In general, the static water level across the NTS is deep, but measured depths vary depending on the land elevation from which each well was drilled. The depth to groundwater in wells at the NTS varies from about $210 \mathrm{~m}(690 \mathrm{ft})$ below the land surface under the Frenchman Flat playa in the southeastern NTS to more than $610 \mathrm{~m}(2,000 \mathrm{ft})$ below the land surface in the northwestern NTS beneath Pahute Mesa (Reiner et al., 1995; Robie et al., 1995; IT, 1996b; O’Hagan and Laczniak, 1996; Bright et al., 2001; Locke and La Camera, 2003; Fenelon, 2005; 2007). Perched groundwater (isolated lenses of water lying above the regional groundwater level) occurs locally throughout the NTS, mainly within the volcanic rocks.

Recharge areas for the Death Valley groundwater system are the higher mountain ranges of central and southern Nevada, where there can be significant precipitation and snowmelt. Groundwater flow is generally from these upland areas to natural discharge areas in the south and southwest. Groundwater at the NTS is also derived from underflow from basins up-gradient of the area (Harrill et al., 1988). The direction of groundwater flow may locally be influenced by structure, rock type, or other geologic conditions. Based on existing water-level data (Hale et al., 1995; Reiner et al., 1995; IT, 1996b; BN, 2003; Fenelon et al., 2008) and flow models (IT, 1996a; D'Agnese et al., 1997; Stoller-Navarro [SNJV], 2006a; 2006b; 2007), the general groundwater flow direction within major water-bearing units beneath the NTS is to the south and southwest.

Most of the natural discharge from the Death Valley flow system is via transpiration by plants or evaporation from soil and playas in the Amargosa Desert and Death Valley. Groundwater discharge at the NTS is minor, consisting of small springs that drain perched water lenses and artificial discharge at a limited number of water supply wells.

Groundwater is the only local source of potable water on the NTS. The nine supply wells that make up the NTS water system (Gillespie et al., 1996) and the other supply wells for the various water systems in the area (town of Beatty, small mines, and local ranches) produce water for human and industrial use from the carbonate, volcanic, and alluvial aquifers. Water chemistry varies from a sodium-potassium-bicarbonate type to a calciummagnesium-carbonate type, depending on the mineralogical composition of the aquifer source. Groundwater quality within aquifers of the NTS is generally acceptable for drinking water and industrial and agricultural uses (Chapman, 1994) and meets Safe Drinking Water Act standards (Chapman and Lyles, 1993; Rose et al., 1997; BN, 2003).

\section{A.2.3 Hydrogeologic Framework for the NTS and Vicinity}

When the need for testing nuclear devices underground was recognized in the 1950s, among the first concerns was the effect testing would have on the groundwater of the area. One of the earliest nuclear tests conducted below the groundwater table (the BILBY test conducted in 1963) was designed in part to study explosion effects on groundwater and the movement in groundwater of radioactive byproducts from the explosion (Hale et al., 1963; Garber, 1971). Since that time additional studies at various scales have been conducted to aid in the understanding of groundwater flow at the NTS. The current understanding of the regional groundwater flow at the NTS is derived from work by Winograd and Thordarson (1975), which was summarized and updated by Laczniak et al. (1996), and has further been developed by the UGTA Sub-Project hydrogeologic modeling team (IT, 1996a; BN, 2002a; 2005; 2006; NSTec, 2007; 2009b). See Chapter 14 for a description of the UGTA SubProject.

Winograd and Thordarson (1975) established a hydrogeologic framework, incorporating the work of Blankennagel and Weir (1973) who defined the first HGUs to address the complex hydraulic properties of volcanic rocks. HGUs are used to categorize lithologic units according to their ability to transmit groundwater, which is mainly a function of their primary lithologic properties, degree of fracturing, and secondary mineral alteration. Hydrostratigraphic units (HSUs) for the NTS volcanic rocks were first defined during the UGTA modeling initiative (IT, 1996a). HSUs are groupings of contiguous stratigraphic units that have a particular hydrogeologic character, such as an aquifer (unit through which water moves readily) or confining unit (unit that generally is impermeable to water movement). The concept of HSUs is very useful in volcanic terrains where stratigraphic units can vary greatly in hydrologic character both laterally and vertically. 
The rocks of the NTS have been classified for hydrologic modeling using this two-level classification scheme in which HGUs are grouped to form HSUs (IT, 1996a; NSTec, 2009b). An HSU may consist of several HGUs, but is defined so that a single general type of HGU dominates (for example, mostly welded-tuff and vitric-tuff aquifers or mostly tuff confining units).

\section{A.2.3.1 Hydrogeologic Units}

All the rocks of the NTS and vicinity can be classified as one of ten HGUs, which include the alluvial aquifer, a playa confining unit, four volcanic HGUs, two intrusive units, and two HGUs that represent the pre-Tertiary rocks (Table A-3).

The deposits of alluvium (alluvial aquifer) fill the main basins of the NTS, and generally consist of a loosely consolidated mixture of boulders, gravel, and sand derived from volcanic and Paleozoic sedimentary rocks (Slate et al., 1999). The finest sediments can be deposited as playa deposits (or dry lake beds) in some closed basins (e.g., Yucca and Frenchman Flats). Because of their silty/clayey nature, these fine-grained units tend to behave hydrologically as confining units (restrictive of groundwater flow).

Table A-3. Hydrogeologic units of the NTS area

\begin{tabular}{|c|c|c|}
\hline $\begin{array}{l}\text { Hydrogeologic Unit } \\
\text { (Symbol) }\end{array}$ & Typical Lithologies & Hydrologic Significance \\
\hline $\begin{array}{l}\text { Alluvial Aquifer } \\
\text { (AA) }\end{array}$ & $\begin{array}{l}\text { Unconsolidated to partially consolidated } \\
\text { gravelly sand, eolian sand, and colluvium; } \\
\text { thin, basalt flows of limited extent }\end{array}$ & $\begin{array}{l}\text { Has characteristics of a highly conductive aquifer, but less so } \\
\text { where lenses of clay-rich paleocolluvium or playa deposits are } \\
\text { present. }\end{array}$ \\
\hline $\begin{array}{l}\text { Playa Confining Unit } \\
(\mathrm{PCU})\end{array}$ & Clayey-silt, sandy-silt & $\begin{array}{l}\text { Surface and near-surface confining unit at Yucca and } \\
\text { Frenchman Lakes and within the lower portion of the alluvial } \\
\text { section in the deepest portions of Frenchman Flat. }\end{array}$ \\
\hline $\begin{array}{l}\text { Welded-Tuff Aquifer } \\
\text { (WTA) }\end{array}$ & Welded ash-flow tuff; vitric to devitrified & $\begin{array}{l}\text { Degree of welding greatly affects interstitial porosity (less } \\
\text { porosity as degree of welding increases) and permeability } \\
\text { (greater fracture permeability as degree of welding increases). }\end{array}$ \\
\hline $\begin{array}{l}\text { Vitric-Tuff Aquifer } \\
\text { (VTA) }\end{array}$ & $\begin{array}{l}\text { Bedded tuff; ash-fall and reworked tuff; } \\
\text { vitric }\end{array}$ & $\begin{array}{l}\text { Constitutes a volumetrically minor hydrogeologic unit. } \\
\text { Generally does not extend far below the static water level due } \\
\text { to tendency to become zeolitized (which drastically reduces } \\
\text { permeability) under saturated conditions. Significant } \\
\text { interstitial porosity ( } 20 \text { to } 40 \text { percent). Generally insignificant } \\
\text { fracture permeability. }\end{array}$ \\
\hline $\begin{array}{l}\text { Lava-Flow Aquifer } \\
\text { (LFA) }\end{array}$ & $\begin{array}{l}\text { Rhyolite, basalt, and dacite lava flows; } \\
\text { includes flow breccias (commonly at base) } \\
\text { and pumiceous zones (commonly at top) }\end{array}$ & $\begin{array}{l}\text { Generally occurs as small, moderately thick (rhyolite) to thin } \\
\text { (basalt) local flows. Hydrologically complex; wide range of } \\
\text { transmissivities; fracture density and interstitial porosity differ } \\
\text { with lithologic variations. }\end{array}$ \\
\hline $\begin{array}{l}\text { Tuff Confining Unit } \\
\text { (TCU) }\end{array}$ & $\begin{array}{l}\text { Zeolitic bedded tuff with interbedded, but } \\
\text { less significant, zeolitic, nonwelded to } \\
\text { partially welded ash-flow tuff }\end{array}$ & $\begin{array}{l}\text { May be saturated but measured transmissivities are very low. } \\
\text { May cause accumulation of perched and/or semi-perched water } \\
\text { in overlying units. }\end{array}$ \\
\hline $\begin{array}{l}\text { Intracaldera Intrusive } \\
\text { Confining Unit } \\
\text { (IICU) }\end{array}$ & $\begin{array}{l}\text { Highly altered, highly injected/intruded } \\
\text { country rock and granitic material }\end{array}$ & $\begin{array}{l}\text { Assumed to be impermeable. Conceptually underlies each of } \\
\text { the SWNVF calderas and Calico Hills. }\end{array}$ \\
\hline $\begin{array}{l}\text { Granite Confining Unit } \\
(\mathrm{GCU})\end{array}$ & Granodiorite, quartz monzonite & $\begin{array}{l}\text { Relatively impermeable; forms local bulbous stocks, north of } \\
\text { Rainier Mesa and Yucca Flat; may contain perched water. }\end{array}$ \\
\hline $\begin{array}{l}\text { Clastic Confining Unit } \\
(\mathrm{CCU})\end{array}$ & Argillite, siltstone, quartzite & $\begin{array}{l}\text { Clay-rich rocks are relatively impermeable; more siliceous } \\
\text { rocks are fractured, but with fracture porosity generally sealed } \\
\text { due to secondary mineralization. }\end{array}$ \\
\hline $\begin{array}{l}\text { Carbonate Aquifer } \\
\text { (CA) }\end{array}$ & Dolomite, limestone & $\begin{array}{l}\text { Transmissivity values differ greatly and are directly dependent } \\
\text { on fracture frequency. }\end{array}$ \\
\hline
\end{tabular}

Note: Adapted from NSTec (2009b). 
The volcanic rocks of the NTS and vicinity can be categorized into four HGUs based on primary lithologic properties, degree of fracturing, and secondary mineral alteration. In general, the altered (typically zeolitized, but hydrothermally altered near caldera margins) volcanic rocks act as confining units (tuff confining unit), and the unaltered rocks form aquifers. The volcanic aquifer units can be further divided into welded-tuff aquifers or vitric-tuff aquifers (depending upon the degree of welding) and lava-flow aquifers. The denser rocks (welded ash-flow tuffs and lava flows) tend to fracture more readily and therefore have relatively high permeability (Blankennagel and Weir, 1973; Winograd and Thordarson, 1975; Laczniak et al., 1996; IT, 1996c; 1997; Prothro and Drellack, 1997).

The pre-Tertiary sedimentary rocks at the NTS and vicinity are also categorized as aquifer or confining unit HGUs based on lithology. The silicic clastic rocks (quartzite, siltstone, shale) tend to be aquitards or confining units, while the carbonates (limestone and dolomite) tend to be aquifers (Winograd and Thordarson, 1975; Laczniak et al., 1996). The granite confining unit is considered to behave as a confining unit due to low primary porosity and low permeability, and because most fractures are probably filled with secondary minerals (Walker, 1962).

\section{A.2.3.2 Hydrostratigraphic Units}

The rocks at the NTS and vicinity are grouped into more than 76 HSUs (NSTec, 2009b). The more important and widespread HSUs in the area are discussed separately below, from oldest to youngest. Additional information regarding other HSUs is summarized in tables introduced in Section A.2.5 below where the hydrogeology of Yucca and Frenchman Flats, and Pahute and Rainier Mesas UGTAs at the NTS is addressed. Additional information can be found in the documentation packages for the UGTA Corrective Action Unit (CAU)-scale hydrogeologic models (BN, 2002b; 2005; 2006; NSTec, 2007).

Lower Clastic Confining Unit (LCCU) - The Proterozoic to Middle-Cambrian-age rocks are largely quartzite and silica-cemented siltstone. Although these rocks are brittle and commonly fractured, secondary mineralization seems to have greatly reduced formation permeability (Winograd and Thordarson, 1975). These units make up the LCCU, which is considered to be the regional hydrologic basement (IT, 1996a). The LCCU is interpreted to underlie the entire region, except at the calderas. Where it is in a structurally high position, the LCCU may act as a barrier to deep regional groundwater flow.

Lower Carbonate Aquifer (LCA) - The LCA consists of thick sequences of Middle Cambrian through Upper Devonian carbonate rocks. This HSU serves as the regional aquifer for most of southern Nevada and, locally, may be as thick as 5,000 m (16,400 ft) (Cole, 1997; Cole and Cashman, 1999). The LCA is present under most of the area, except where the LCCU is structurally high and at the calderas. Transmissivities of these rocks differ from place to place, apparently reflecting the observed differences in fracture and fault densities and characteristics (Winograd and Thordarson, 1975; NSTec, 2009c).

Upper Clastic Confining Unit (UCCU) - Upper Devonian and Mississippian silicic clastic rocks in the NTS vicinity are assigned to the Eleana Formation and the Chainman Shale (Trexler et al., 1996; 2003; Cashman and Trexler, 1991). Both formations are grouped into the UCCU. At the NTS, this HSU is found mainly within a north-south band along the western portion of Yucca Flat. It is a significant confining unit and in many places forms the footwall of the Belted Range and CP thrust faults.

Lower Carbonate Aquifer, Upper Thrust Plate (LCA3) - Cambrian through Devonian, mostly carbonate rocks that occur in the hanging wall of the Belted Range and CP thrust faults are designated as LCA3. These rocks are equivalent stratigraphically to the LCA, but are structurally separated from the LCA by the Belted Range thrust fault. The LCA3 is patchily distributed as remnant thrust blocks, particularly along the western and southern sides of Yucca Flat (at Mine Mountain and the CP Hills), at Calico Hills, and at Bare Mountain.

Mesozoic Granite Confining Unit (MGCU) - The Mesozoic era is represented at the NTS only by intrusive igneous rocks. Cretaceous-age granitic rocks are exposed at two locations: in northern Yucca Flat at the Climax 
Stock, and the Gold Meadows Stock, which lies $12.9 \mathrm{~km}(8 \mathrm{mi})$ west of the Climax Stock, just north of Rainier Mesa (Snyder, 1977; Bath et al., 1983) (Figure A-2). The two are probably related in both source and time and are believed to be connected at depth (Jachens, 1999). Because of its low intergranular porosity and permeability, and the lack of inter-connecting fractures (Walker, 1962), the MGCU is considered a confining unit. The Climax and Gold Meadows intrusives are grouped into the MGCU HSU.

Tertiary and Quaternary Hydrostratigraphic Units - Tertiary- and Quaternary-age strata at the NTS are organized into dozens of HSUs. Nearly all are of volcanic origin, except the alluvial aquifer and playa confining unit (PCU), which are the uppermost HSUs. These rocks are important because (1) most of the underground nuclear tests at the NTS were conducted in these units, (2) they constitute a large percentage of the rocks in the area, and (3) they are inherently complex and heterogeneous. As pointed out in Section A.2.3.1, the volcanic rocks are divided into aquifer or confining units according to lithology and secondary alteration. More detailed information can be found in the documentation packages for the UGTA CAU-scale hydrogeologic models (BN, 2002b; 2005; 2006; NSTec, 2007).

Alluvial Aquifer (AA) - The alluvium throughout most of the NTS is a loosely consolidated mixture of detritus derived from silicic volcanic and Paleozoic-age sedimentary rocks, ranging in particle size from clay to boulders. Sediment deposition is largely in the form of alluvial fans (debris flows, sheet wash, and braided streams), which coalesce to form discontinuous, gradational, and poorly sorted deposits. Eolian sand, playa deposits, and rare basalt flows are also present within the alluvial section of some valleys. The alluvium thickness in major valleys (e.g., Frenchman Flat and Yucca Flat) generally ranges from about $30 \mathrm{~m}(100 \mathrm{ft})$ to more than 1,128 $\mathrm{m}(3,700 \mathrm{ft})$ in the deepest subbasins. The AA HSU is restricted primarily to the basins of the NTS. However, because the water table in the vicinity is moderately deep, the alluvium is generally unsaturated, except in the deep subbasins of some valleys. These sediments are porous and, thus, have high storage coefficients. Hydraulic conductivity may also be high, particularly in the coarser, gravelly beds.

\section{A.2.4 General Hydraulic Characteristics of NTS Rocks}

Volcanic rocks typically are extremely variable in lithologic character both laterally and vertically. The characteristics of rocks that control the density and character of fractures are the primary determinants of their hydraulic properties, and most hydraulic heterogeneity ultimately is related to fracture characteristics such as fracture density, openness, orientation, and other properties. Secondary fracture-filling minerals can drastically obstruct the flow through or effectively seal an otherwise transmissive formation (IT, 1996c; Drellack et al., 1997). Fracture density typically increases with proximity to faults, potentially increasing the hydraulic conductivity of the formation; however, the hydrologic properties of faults, per se, are not well known. Limited data suggest that the full spectrum of hydraulic properties, from barrier to conduit, may be possible (Blankennagel and Weir, 1973; Faunt, 1998).

Table A-4 includes a brief summary of the hydrologic properties of NTS HGUs. The lowest transmissivity values in volcanic rocks at the NTS are typically associated with non-welded ash-flow tuff and bedded tuff (ash-fall and reworked tuffs). Although interstitial porosity may be high, the interconnectivity of the pore space is poor, and these relatively incompetent rocks tend not to support open fractures. Secondary alteration of these tuffs (most commonly, zeolitization) ultimately yields a very impermeable unit. As described in Section A.2.3.1 and in NSTec (2009b), these zeolitized tuffs are considered to be confining units. The equivalent unaltered bedded and non-welded tuffs are considered to be vitric-tuff aquifers, and have intermediate transmissivities.

In general, the most transmissive rocks tend to be moderately to densely welded ash-flow tuffs (welded-tuff aquifer), rhyolite lava flows (lava-flow aquifer), and carbonate rocks (limestone and dolomite). Although their interstitial porosity is low, these competent lithologies tend to be highly fractured, and groundwater flow through these rocks is largely through an interconnected network of fractures (Blankennagel and Weir, 1973; GeoTrans, 1995).

Underground nuclear explosions affect hydraulic properties of the geologic medium, creating both long-term and short-term effects. Effects include enhanced permeability from shock-induced fractures, the formation of vertical 
conduits (e.g., collapse chimneys), and elevated water levels (mounding and over-pressurization of saturated low-permeability units). However, these effects tend to be localized (Borg et al., 1976; Brikowski, 1991; Allen et al., 1997).

Table A-4. Summary of hydrologic properties for hydrogeologic units at the NTS

\begin{tabular}{|c|c|c|c|c|}
\hline \multicolumn{3}{|c|}{ Hydrogeologic Unit ${ }^{(a)}$} & Fracture Density $^{(b, c)}$ & $\begin{array}{c}\text { Relative Hydraulic } \\
\text { Conductivity }^{(c)}\end{array}$ \\
\hline \multicolumn{3}{|c|}{ Alluvial Aquifer } & Very low & Moderate to very high \\
\hline \multicolumn{3}{|c|}{ Vitric-Tuff Aquifer } & Low & Low to moderate \\
\hline \multicolumn{3}{|c|}{ Welded-Tuff Aquifer } & Moderate to high & Moderate to very high \\
\hline \multirow{4}{*}{$\begin{array}{l}\text { Lava-Flow } \\
\text { Aquifer }^{(d)}\end{array}$} & \multirow{2}{*}{$\begin{array}{l}\text { Pumiceous } \\
\text { Lava }\end{array}$} & Vitric & Low & Low to moderate \\
\hline & & Zeolitic & Low & Very low \\
\hline & \multicolumn{2}{|c|}{ Stony Lava and Vitrophyre } & Moderate to high & Moderate to very high \\
\hline & \multicolumn{2}{|c|}{ Flow Breccia } & Low to moderate & Low to moderate \\
\hline \multicolumn{3}{|c|}{ Tuff Confining Unit } & Low & Very low \\
\hline \multicolumn{3}{|c|}{ Intrusive Confining Unit } & Low to moderate & Very low \\
\hline \multicolumn{3}{|c|}{ Granite Confining Unit } & Low to moderate & Very low \\
\hline \multicolumn{3}{|c|}{ Carbonate Aquifer } & Low to high (variable) & Low to very high \\
\hline \multicolumn{3}{|c|}{ Clastic Confining Unit } & Moderate & Very low to low ${ }^{(\mathrm{e})}$ \\
\hline
\end{tabular}

(a) Refer to Table A-3 for hydrogeologic nomenclature.

(b) Including primary (cooling joints in tuffs) and secondary (tectonic) fractures.

(c) The values presented are the authors' qualitative estimates based on data from published (IT [1996c], Blankennagel and Weir [1973], Winograd and Thordarson [1975], and unpublished sources (e.g., numerous Los Alamos and Lawrence Livermore National Laboratories drill-hole characterization reports).

(d) Abstracted from Prothro and Drellack (1997).

(e) Fractures tend to be sealed by the presence of secondary minerals.

Note: Adapted from BN (2002b).

\section{A.2.5 Hydrogeology of the NTS Underground Test Areas}

Most NTS underground nuclear detonations were conducted in three main UGTAs (Figure A-6; U.S. Department of Energy, Nevada Operations Office [DOE/NV], 2000): (1) Yucca Flat, (2) Pahute Mesa, and (3) Rainier Mesa (including Aqueduct Mesa). Underground tests in Yucca Flat and Pahute Mesa typically were conducted in vertical drill holes, whereas almost all tests conducted in Rainier Mesa were tunnel emplacements. A total of 85 underground tests ( 85 detonations) were conducted on Pahute Mesa, including 18 high-yield detonations (more than 200 kilotons [kt]). Rainier Mesa hosted 61 underground tests (62 detonations), almost all of which were relatively low-yield (generally less than $20 \mathrm{kt}$ ), tunnel-based weapons-effects tests. Yucca Flat was the most extensively used UGTA, hosting 659 underground tests (747 detonations), 4 of which were high-yield detonations (Allen et al., 1997; DOE/NV, 2000).

In addition to the three main UGTAs, underground nuclear tests were conducted in Frenchman Flat (ten tests), Shoshone Mountain (six tests), the Oak Spring Butte/Climax Mine area (three tests), the Buckboard Mesa area (three tests), and Dome Mountain (one test with five detonations) (Allen et al., 1997; DOE/NV, 2000). It should be noted that these totals include nine cratering tests (13 total detonations) conducted in various areas of the NTS. Table A-5 is a synopsis of information about each UGTA at the NTS, and Figure A- 6 shows the aerial distribution of underground nuclear tests conducted at the NTS. 


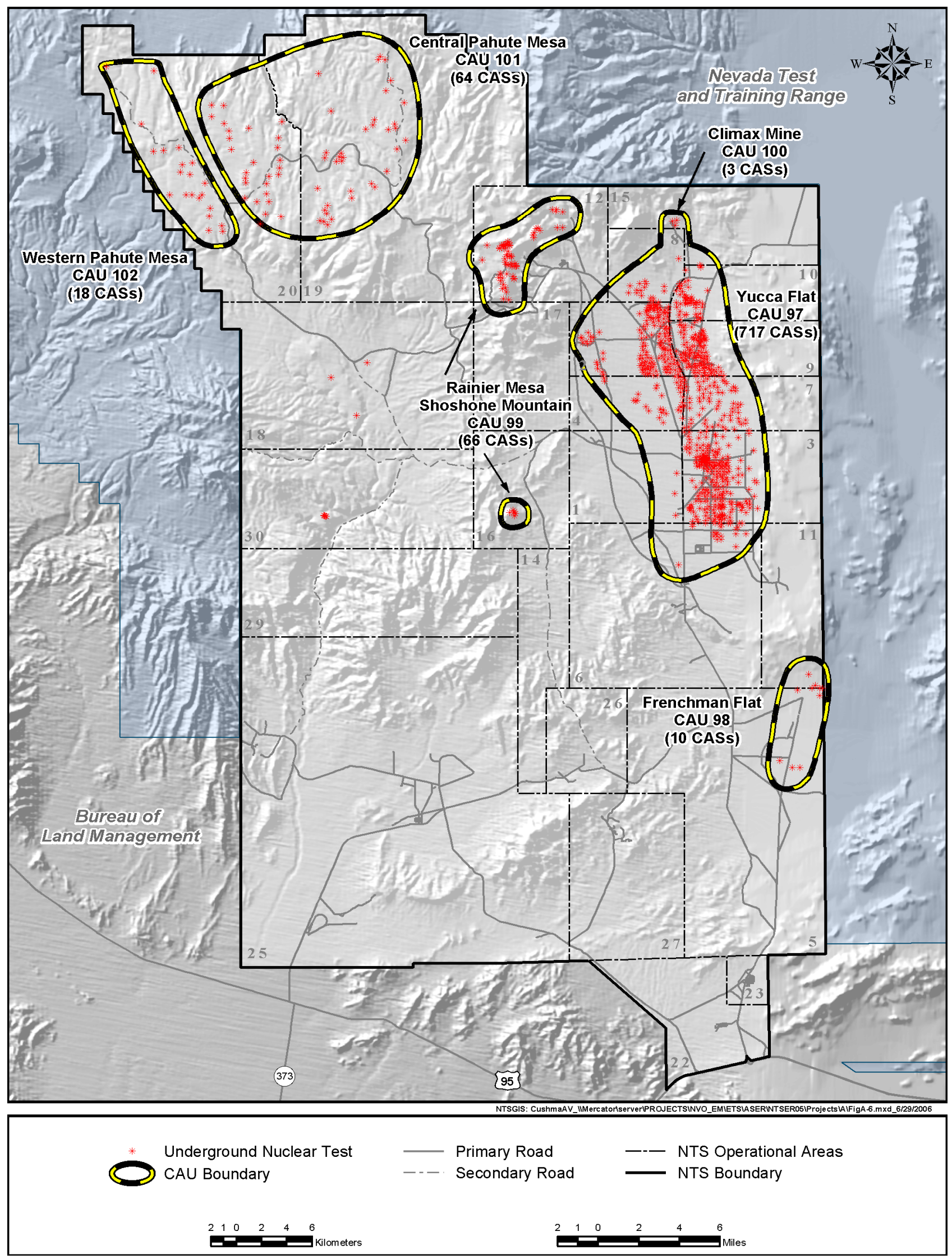

Figure A-6. Location of Corrective Action Units and Corrective Action Sites on the NTS 
Table A-5. Information summary of NTS underground nuclear tests

\begin{tabular}{|c|c|c|c|c|c|c|c|}
\hline \multirow[b]{2}{*}{ Physiographic Area } & \multirow{2}{*}{$\begin{array}{c}\text { NTS } \\
\text { Area(s) }\end{array}$} & \multicolumn{2}{|c|}{ Total Underground $^{(a)}$} & \multirow{2}{*}{$\begin{array}{c}\text { Test } \\
\text { Dates }^{(a)}\end{array}$} & \multirow{2}{*}{$\begin{array}{c}\text { Depth of } \\
\text { Burial Range }\end{array}$} & \multirow{2}{*}{$\begin{array}{l}\text { Overburden } \\
\text { Media }\end{array}$} & \multirow[b]{2}{*}{ Comments } \\
\hline & & Tests & Detonations & & & & \\
\hline Yucca Flat & $\begin{array}{c}1,2,3,4,6 \\
7,8,9,10\end{array}$ & 659 & 747 & 1951-1992 & $\begin{array}{l}27-1,219 \mathrm{~m} \\
(89-3,999 \mathrm{ft})\end{array}$ & $\begin{array}{l}\text { Alluvium/playa, } \\
\text { Volcanic tuff, } \\
\text { Paleozoic rocks }\end{array}$ & $\begin{array}{l}\text { Various test types and yields; almost all were } \\
\text { vertical emplacements above and below static water } \\
\text { level; includes four high-yield }{ }^{(\text {) }} \text { detonations. }\end{array}$ \\
\hline Pahute Mesa & 19,20 & 85 & 85 & 1965-1992 & $\begin{array}{c}31-1,452 \mathrm{~m} \\
(100-4,765 \mathrm{ft})\end{array}$ & $\begin{array}{l}\text { Alluvium, (thin) } \\
\text { volcanic tuffs and } \\
\text { lavas }\end{array}$ & $\begin{array}{l}\text { Almost all were large-diameter vertical } \\
\text { emplacements above and below static water level; } \\
\text { includes } 18 \text { high-yield detonations. }\end{array}$ \\
\hline Rainier/Aqueduct Mesa & 12 & 61 & 62 & 1957-1992 & $\begin{array}{c}61-640 \mathrm{~m} \\
(200-2,100 \mathrm{ft})\end{array}$ & $\begin{array}{l}\text { Tuffs with welded } \\
\text { tuff caprock (little } \\
\text { or no alluvium) }\end{array}$ & $\begin{array}{l}\text { Two vertical emplacements; all others were } \\
\text { horizontal tunnel emplacements above static water } \\
\text { level; mostly low-yield }{ }^{(\mathrm{c})} \text { U.S. Department of } \\
\text { Defense weapons effects tests. }\end{array}$ \\
\hline Frenchman Flat & 5,11 & 10 & 10 & $1965-1971$ & $\begin{array}{c}179-296 \mathrm{~m} \\
(587-971 \mathrm{ft})\end{array}$ & $\begin{array}{l}\text { Mostly alluvium, } \\
\text { minor volcanic } \\
\text { tuff }\end{array}$ & $\begin{array}{l}\text { Various emplacement configurations, both above } \\
\text { and below static water level. }\end{array}$ \\
\hline Shoshone Mountain & 16 & 6 & 6 & $1962-1971$ & $\begin{array}{c}244-640 \mathrm{~m} \\
(800-2,100 \mathrm{ft})\end{array}$ & Bedded tuff & $\begin{array}{l}\text { Tunnel-based low-yield weapons effects and Vela } \\
\text { Uniform tests. }\end{array}$ \\
\hline $\begin{array}{l}\text { Oak Spring Butte (Climax } \\
\text { Area) }\end{array}$ & 15 & 3 & 3 & $1962-1966$ & $\begin{array}{c}229-351 \mathrm{~m} \\
(750-1,150 \mathrm{ft})\end{array}$ & Granite & $\begin{array}{l}\text { Three tests above static water level. (HARD HAT, } \\
\text { TINY TOT, and PILE DRIVER). }\end{array}$ \\
\hline Buckboard Mesa & 18 & 3 & 3 & $1962-1964$ & $\begin{array}{l}\leq 27 \mathrm{~m} \\
(90 \mathrm{ft})\end{array}$ & Basaltic lavas & $\begin{array}{l}\text { Shallow, low-yield experiments (SULKY, } \\
\text { JOHNNIE BOY(d) and DANNY BOY); all were } \\
\text { above static water level. }\end{array}$ \\
\hline Dome Mountain & 30 & 1 & 5 & $03 / 12 / 1968$ & $\begin{array}{c}50 \mathrm{~m} \\
(165 \mathrm{ft})\end{array}$ & Mafic lava & $\begin{array}{l}\text { BUGGY (A, B, C, D, and E); Plowshare cratering } \\
\text { test using a 5-detonation-horizontal salvo; all above } \\
\text { static water level. }\end{array}$ \\
\hline
\end{tabular}

(a) Source: DOE/NV, 2000

Source: Allen et al., 1997

(b) High-yield detonations - detonations more than $200 \mathrm{kt}$.

(c) Low-yield detonations - detonations less than $20 \mathrm{kt}$.

(d) JOHNNIE BOY was detonated at a depth of $1.75 \mathrm{ft}$ (essentially a surface burst) approximately 1 mile east of Buckboard Mesa. 
The location of each underground nuclear test is classified as a Corrective Action Site (CAS). These in turn have been grouped into six CAUs, according to the Federal Facility Agreement and Consent Order (FFACO), as amended (February 2008), between the DOE and the State of Nevada. In general, the CAUs relate to the geographical UGTAs on the NTS (see Figure A-6).

The hydrogeology of the four main NTS UGTAs is summarized in the following subsections. For detailed stratigraphic descriptions of geologic units at the NTS (including each of the UGTAs), see Sawyer et al. (1994) and Slate et al. (1999).

\section{A.2.5.1 Frenchman Flat Underground Test Area}

The Frenchman Flat CAU consists of ten CASs located in the northern part of NTS Area 5 and southern part of Area 11 (see Figure A-6). The detonations were conducted in vertical emplacement holes and two mined shafts. Nearly all the tests were conducted in alluvium above the water table (BN, 2005).

Physiography - Frenchman Flat is a closed intermontane basin located in the southeastern portion of the NTS. It is bounded on the north by Massachusetts Mountain and the Halfpint Range, on the east by the Buried Hills, on the south by the Spotted Range, and on the west by the Wahmonie volcanic center (see Figure A-2). The sparsely vegetated valley floor slopes gently toward a central playa lakebed. Ground-level elevations range from $938 \mathrm{~m}(3,078 \mathrm{ft})$ above sea level at the playa, to over 1,463 $\mathrm{m}(4,800 \mathrm{ft})$ in the nearby surrounding mountains.

Geology Overview - The stratigraphic section for Frenchman Flat consists of (from oldest to youngest) Proterozoic and Paleozoic clastic and carbonate rocks, Tertiary sedimentary and tuffaceous sedimentary rocks, Tertiary volcanic rocks, and Quaternary and Tertiary alluvium (Slate et al., 1999). In the northernmost portion of Frenchman Flat, the middle to upper Miocene volcanic rocks that erupted from calderas located to the northwest of Frenchman Flat unconformably overlie Ordovician-age carbonate and clastic rocks. To the south, these volcanic units, including the Ammonia Tanks Tuff, Rainier Mesa Tuff, Topopah Spring Formation, and Crater Flat Group, either thin considerably, interfinger with coeval sedimentary rocks, or pinch out together (BN, 2005). Upper-middle Miocene tuffs, lavas, and debris flows from the Wahmonie volcanic center located just west of Frenchman Flat dominate the volcanic section beneath the western portion of the valley. To the south and southeast, most of the volcanic units are absent, and Oligocene to middle Miocene sedimentary and tuffaceous sedimentary rocks, which unconformably overlie the Paleozoic rocks in the southern portion of Frenchman Flat, dominate the Tertiary section (Prothro and Drellack, 1997). In most of the Frenchman Flat area, upper Miocene to Holocene alluvium covers the older sedimentary and volcanic rocks (Slate et al., 1999). Alluvium thicknesses range from a thin veneer along the valley edges to perhaps as much as $1,158 \mathrm{~m}(3,800 \mathrm{ft})$ in north central Frenchman Flat.

Structural Setting - The structural geology of Frenchman Flat is complex. During the late Mesozoic era, the region was subjected to compressional deformation, which resulted in folding, thrusting, uplift, and erosion of the pre-Tertiary rocks (Barnes et al., 1982). Approximately $16 \mathrm{Ma}$, the region underwent extensional deformation, during which the present basin-and-range topography was developed, and the Frenchman Flat basin was formed (Ekren et al., 1968). In the immediate vicinity of Frenchman Flat, extensional deformation has produced northeast-trending, left-lateral strike-slip faults and generally north-trending normal faults that displace the Tertiary and pre-Tertiary rocks. Beneath Frenchman Flat, major west-dipping normal faults merge and are probably contemporaneous with strike-slip faults beneath the southern portion of the basin (Grauch and Hudson, 1995). Movement along the faults has created a relatively deep, east-dipping, half-graben basin elongated in a northeasterly direction (Figure A-7).

Hydrogeology Overview - The hydrogeology of Frenchman Flat is fairly complex, but is typical of the NTS area. Many of the HGU and HSU building blocks developed for the NTS vicinity are applicable to the Frenchman Flat basin. The strata in the Frenchman Flat area have been subdivided into nine Tertiary-age HSUs (six Quaternary/Tertiary alluvium and volcanic units and three pre-Tertiary HSUs to serve as layers for the UGTA Frenchman Flat CAU groundwater model (BN, 2005). The dominant units are, in descending order, the AA, the Timber Mountain aquifer (TMA), the Topopah Spring aquifer (TSA), the Wahmonie confining unit (WCU), the lower tuff confining unit (LTCU), the volcaniclastic confining unit (VCU), the LCA, and the LCCU (Table A-6). 


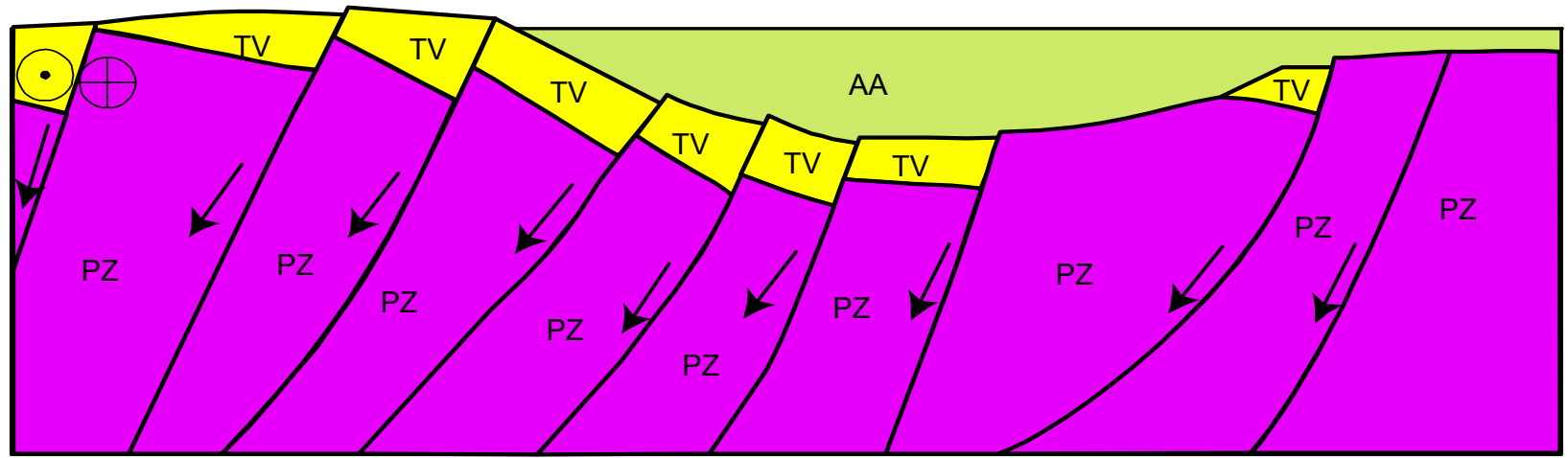

\section{NO SCALE}

$A A=$ Alluvial Aquifer (Quaternary/Tertiary Alluvium)

- Movement away from viewer.
TV $=$ Volcanic Aquifers and Confining Units (Tertiary Volcanic Rocks)

\begin{abstract}
$\mathrm{PZ}=$ Lower Carbonate Aquifer (Folded and Faulted pre-Tertiary Sedimentary Rocks)

= Movement toward viewer.
\end{abstract}

Figure A-7. Conceptual east-west cross section through Frenchman Flat

Table A-6. Hydrostratigraphic units of the Frenchman Flat underground test area

\begin{tabular}{|c|c|c|}
\hline $\begin{array}{l}\text { Hydrostratigraphic Unit } \\
\text { (Symbol) }\end{array}$ & $\begin{array}{l}\text { Dominant } \\
\text { Hydrogeologic } \\
\text { Unit }^{(\mathbf{a})}\end{array}$ & Typical Lithologies \\
\hline $\begin{array}{l}\text { Alluvial Aquifer } \\
\text { (AA) }\end{array}$ & AA, minor LFA & $\begin{array}{l}\text { Alluvium (gravelly sand); also includes relatively thin } \\
\text { basalt flow in northern Frenchman Flat and playa deposits } \\
\text { in south-central part of basin }\end{array}$ \\
\hline $\begin{array}{l}\text { Timber Mountain Aquifer } \\
\text { (TMA) }\end{array}$ & WTA, VTA & $\begin{array}{l}\text { Welded ash-flow tuff and related nonwelded and ash-fall } \\
\text { tuffs; vitric to devitrified }\end{array}$ \\
\hline $\begin{array}{l}\text { Topopah Spring Aquifer } \\
\text { (TSA) }\end{array}$ & WTA & Welded ash-flow tuff; vitric to devitrified \\
\hline $\begin{array}{l}\text { Wahmonie Volcanic Confining Unit } \\
\text { (WVCU) }\end{array}$ & TCU, minor LFA & $\begin{array}{l}\text { Ash-fall and reworked tuffs; debris and breccia flows; } \\
\text { minor intercalated lava flows. Typically altered: zeolitic } \\
\text { to argillic }\end{array}$ \\
\hline $\begin{array}{l}\text { Lower Tuff Confining Unit } \\
\text { (LTCU) }\end{array}$ & TCU & $\begin{array}{l}\text { Zeolitic bedded tuffs, with interbedded but less significant } \\
\text { zeolitic, nonwelded to partially welded ash-flow tuffs }\end{array}$ \\
\hline $\begin{array}{l}\text { Volcaniclastic Confining Unit } \\
\text { (VCU) }\end{array}$ & TCU, minor AA & $\begin{array}{l}\text { Diverse assemblage of interbedded volcanic and } \\
\text { sedimentary rocks including tuffs, shale, tuffaceous and } \\
\text { argillaceous sandstones, conglomerates, minor limestones }\end{array}$ \\
\hline $\begin{array}{l}\text { Upper Clastic Confining Unit } \\
\text { (UCCU) }\end{array}$ & $\mathrm{CCU}$ & $\begin{array}{l}\text { Argillite, quartzite; present only in northwest portion of } \\
\text { model in the CP Basin }\end{array}$ \\
\hline $\begin{array}{l}\text { Lower Carbonate Aquifer } \\
\text { (LCA) }\end{array}$ & $\mathrm{CA}$ & Dolomite and limestone; the "regional aquifer" \\
\hline $\begin{array}{l}\text { Lower Clastic Confining Unit } \\
\text { (LCCU) }\end{array}$ & $\mathrm{CCU}$ & Quartzites and siltstones; the "hydrologic basement" \\
\hline
\end{tabular}

(a) See Table A-3 for descriptions of HGUs.

Note: Adapted from BN, 2005. 
Water-level Elevation and Groundwater Flow Direction - The depth to the static water level (SWL) in Frenchman Flat ranges from $210 \mathrm{~m}(690 \mathrm{ft})$ near the central playa to more than $350 \mathrm{~m}(1,150 \mathrm{ft})$ at the northern end of the valley (SNJV, 2004a; 2006a). The SWL is generally located within the AA, TMA, WVCU, or LTCU. In the deeper, central portions of the basin, more than half of the alluvium section is saturated. Water-level elevation data in the AA indicate a very flat water table (Blout et al., 1994; SNJV, 2004a; 2006a).

Water-level data for the LCA in the southern part of the NTS are limited, but indicate a fairly low gradient in the Yucca Flat, Frenchman Flat, and Jackass Flats areas. This gentle gradient implies a high degree of hydraulic continuity within the aquifer, presumably due to high fracture permeability (Laczniak et al., 1996). Furthermore, the similarity of the water levels measured in Paleozoic rocks (LCA) in Yucca Flat and Frenchman Flat implies that, at least for deep interbasin flow, there is no groundwater barrier between the two basins. Inferred regional groundwater flow through Frenchman Flat is to the south-southwest toward discharge areas in Ash Meadows (see Figure A-5). An increasing westward flow vector in southern NTS may be due to preferential flow paths subparallel to the northeast-trending Rock Valley fault (Grauch and Hudson, 1995) and/or a northward gradient from the Spring Mountain recharge area (IT, 1996a; 1996b).

Groundwater elevation measurements for wells completed in the AA and TMA are higher than those in the underlying LCA (IT, 1996b; BN, 2005; SNJV, 2006a). This implies a downward gradient. This apparent semiperched condition is believed to be due to the presence of intervening LTCU and VCU.

\section{A.2.5.2 Yucca Flat/Climax Mine Underground Test Area}

The Yucca Flat/Climax Mine CAU consists of several hundreds of CASs located in NTS Areas 1, 2, 3, 4, 6, 7, 8, 9, and 10, and three CASs located in Area 15 (see Figure A-6). These tests were typically conducted in vertical emplacement holes and a few related tunnels (see Table A-5).

The Yucca Flat and Climax Mine UGTAs were originally defined as two separate CAUs (CAU 97 and CAU 100) in the FFACO because the geologic frameworks of the two areas are distinctly different. The Yucca Flat underground nuclear tests were conducted in alluvial, volcanic, and carbonate rocks, whereas the Climax Mine tests were conducted in an igneous intrusion in northern Yucca Flat. However, particle-tracking simulations performed during the regional evaluation (IT, 1997) indicated that the local Climax Mine groundwater flow system merges into the much larger Yucca Flat groundwater flow system during the 1,000-year time period of interest, so the two areas were combined into the single CAU 97.

Yucca Flat was the most heavily used UGTA on the NTS (see Figure A-6). The alluvium and tuff formations provide many characteristics advantageous to the containment of nuclear explosions. They are easily mined or drilled. The high-porosity overburden (alluvium and vitric tuffs) will accept and depressurize any gas that might escape the blast cavity. The deeper tuffs are zeolitized, which creates a nearly impermeable confining unit. The zeolites also have absorptive and "molecular sieve" attributes that severely restrict or prevent the migration of radionuclides (Carle et al., 2008). The deep water table (greater than $503 \mathrm{~m}$ [1,650 ft] depth) provides additional operational and environmental benefits.

This section provides brief descriptions of the geologic and hydrogeologic setting of the Yucca Flat/Climax Mine UGTA, as well as a discussion of the hydrostratigraphic framework. This summary was compiled from various sources, including Winograd and Thordarson (1975), Byers et al. (1989), Laczniak et al. (1996), Cole (1997), IT (2002), and BN (2006), where additional information can be found.

Physiography - Yucca Flat is a topographically closed basin with a playa at its southern end. The geomorphology of Yucca Flat is typical of the arid, inter-mountain basins found throughout the Basin and Range province of Nevada and adjoining states. Faulted and tilted blocks of Tertiary-age volcanic rocks and underlying Precambrian and Paleozoic sedimentary rocks form low ranges around the basin (see Figure A-2). These rocks also compose the "basement" of the basin, which is now covered by alluvium. 
Ground elevation in the Yucca Flat area ranges from about 1,195 m (3,920 ft) above mean sea level at Yucca Lake (playa) in the southern portion to about $1,463 \mathrm{~m}(4,800 \mathrm{ft})$ in the northern portion of the valley. The highest portions of the surrounding mountains and hills range from less than $1,500 \mathrm{~m}(5,000 \mathrm{ft})$ in the south to over $2,316 \mathrm{~m}(7,600 \mathrm{ft})$ at Rainier Mesa in the northwest corner of the area. Yucca Flat is bounded by the Halfpint Range to the east, by Rainier Mesa and the Belted Range to the north, by the Eleana Range and Mine Mountain to the west, and by the CP Hills, CP Hogback, and Massachusetts Mountain to the south.

Geology Overview - The Precambrian and Paleozoic rocks of the NTS area consist of approximately 11,300 m $(37,000 \mathrm{ft})$ of carbonate and silicic clastic rocks (Cole, 1997). These rocks were severely deformed by compressional movements during Mesozoic time, which resulted in the formation of folds and thrust faults (e.g., Belted Range and CP thrust faults). During the middle Late Cretaceous, granitic bodies (such as the Climax stock in northern Yucca Flat) intruded these deformed rocks (Houser and Poole, 1960; Maldonado, 1977).

A total of 22 pre-Tertiary formations (including the Mesozoic granitic intrusives) has been recognized in the Yucca Flat region (see Table A-2). These rocks range in age from Precambrian to Cretaceous and represent primarily carbonate and silicic shallow- to deep-water sedimentation near a continental margin. Some of these units are widespread throughout southern Nevada and California, though complex structural deformation has created many uncertainties in determining the geometric relationships of these units around Yucca Flat.

During Cenozoic time, the sedimentary and intrusive rocks were buried by thick sections of volcanic material deposited in several eruptive cycles from source areas in the SWNVF. The Cenozoic stratigraphy of the Yucca Flat area, though not structurally complicated, is very complex. Most of the volcanic rocks of the Yucca Flat area were deposited during many eruptive cycles of the SWNVF (see Section A.1.1). The source areas of most units (Volcanics of Oak Spring Butte, Tunnel Formation, Belted Range Group, Crater Flat Group, Calico Hills Formation, Paintbrush Group, and Timber Mountain Group) are located to the west and northwest of Yucca Flat; the Wahmonie source area is located southwest of Yucca Flat. Table A-1 includes the Tertiary stratigraphic units common to the Yucca Flat basin.

The volcanic rocks include primarily ash-flow tuffs, ash-fall tuffs, and reworked tuffs, whose thicknesses and extents vary partly due to the irregularity of the underlying depositional surface, and partly due to the presence of topographic barriers and windows between Yucca Flat and the source areas to the north and west.

Over the last several million years, gradual erosion of the highlands that surround Yucca Flat has deposited a thick blanket of alluvium on the tuff section. The alluvium in Yucca Flat, and throughout most of the NTS, is a loosely consolidated mixture of detritus derived from silicic volcanic and Paleozoic sedimentary rocks, ranging in particle size from clay to boulders. Sediment deposition is largely in the form of alluvial fans (debris flows, sheet wash, and braided streams) which coalesce to form discontinuous, gradational, and poorly sorted deposits. Eolian sand, playa deposits, and rare basalt flows are also present within the alluvium section of Yucca Flat. The

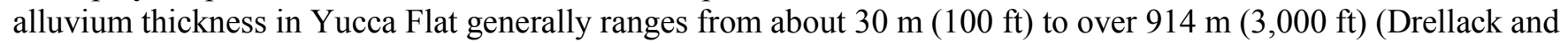
Thompson, 1990).

Structural Setting - The structure of the pre-Tertiary rocks in Yucca Flat is complex and poorly known (Cole, 1997), but it is important because the pre-Tertiary section is very thick and extensive and includes units that form regional aquifers. The main pre-Tertiary structures in the Yucca Flat area are related to the east-vergent Belted Range thrust fault, which has placed Late Proterozoic to Cambrian-age rocks over rocks as young as Late Mississippian (Cole, 1997; Cole and Cashman, 1999). In several places along the western and southern portions of Yucca Flat, east-vergent structures related to the Belted Range thrust were deformed by younger west-vergent structural activity (Cole and Cashman, 1999). This west-vergent deformation is related to the CP thrust fault, which also placed Cambrian and Ordovician rocks over Mississippian and Pennsylvanian-age rocks beneath western Yucca Flat (Caskey and Schweickert, 1992).

Large-scale normal faulting began in Yucca Flat in response to regional extensional movements near the end of this period of volcanism. This faulting formed the Yucca Flat basin. As fault movement continued, blocks between faults were down-dropped and tilted, creating subbasins within the Yucca Flat basin. 
Over the last several million years, gradual erosion of the highlands that surround Yucca Flat has deposited a thick blanket of alluvium on the tuff section. The thickness of the alluvium in the Yucca Flat basin varies as a function of the topography of the underlying deposits and due to continuing movements along faults during alluvium deposition.

The major basin-forming faults generally strike in a northerly direction, and relative offset is typically down to the east (e.g., Yucca, Topgallant, and Carpetbag faults). Movement along the Yucca fault in central Yucca Flat indicates deformation in the area has continued into the Holocene (Hudson, 1992). Specific details regarding these faults are lacking because of the propensity to avoid inferred and known faults during drilling of emplacement holes for underground nuclear tests.

The configuration of the Yucca Flat basin is illustrated on the generalized west-east cross section shown in Figure A-8. The cross section is simplified to show the positions of only the primary lithostratigraphic units in the region. This cross section provides a conceptual illustration of the irregular Precambrian and Paleozoic rocks overlain by the Tertiary volcanic units, and the basin-filling alluvium at the surface. The main Tertiary-age, basin-forming large-scale normal faults are also shown.

Hydrogeologic Overview - All the rocks of the Yucca Flat underground test area can be classified as one of eight HGUs (see Table A-3), which include the AA, four volcanic HGUs, an intrusive unit, and two HGUs that represent the pre-Tertiary rocks.

The strata in Yucca Flat have been subdivided into 11 Tertiary-age HSUs (including the Tertiary/Quaternary alluvium), 1 Mesozoic intrusive HSU, and 6 Paleozoic HSUs (BN, 2006). These units are listed in Table A-7, and several of the more important HSUs are discussed in the following paragraphs. The alluvium and preTertiary HSUs in Yucca Flat are as defined in Section A.2.3.2.

The hydrostratigraphy for the Tertiary-age volcanic rocks in Yucca Flat can be simplified into two categories: zeolitic tuff confining units and (non-zeolitic) volcanic aquifers.

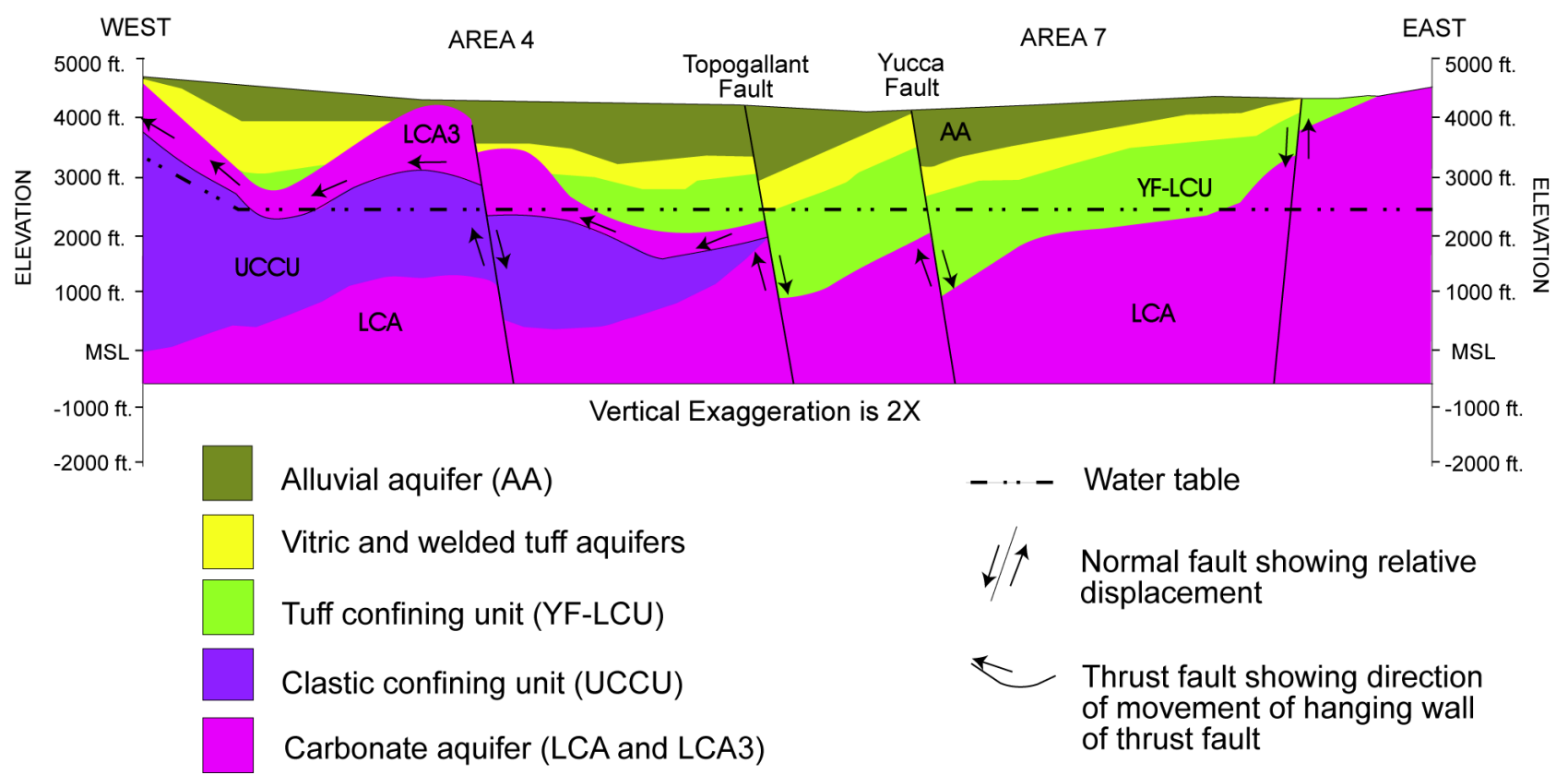

Figure A-8. Generalized west-east hydrogeologic cross section through central Yucca Flat 
Table A-7. Hydrostratigraphic units of the Yucca Flat underground test area

\begin{tabular}{|c|c|c|}
\hline $\begin{array}{l}\text { Hydrostratigraphic Unit } \\
\text { (Symbol) }\end{array}$ & $\begin{array}{c}\text { Dominant } \\
\text { Hydrogeologic }^{\text {Units }} \\
\text { Un) }^{(a)}\end{array}$ & Typical Lithologies \\
\hline $\begin{array}{l}\text { Alluvial Aquifer } \\
\text { (AA) }\end{array}$ & AA, minor LFA & $\begin{array}{l}\text { Alluvium (gravelly sand); also includes one or more } \\
\text { thin basalt flows, playa deposits and eolian sands }\end{array}$ \\
\hline $\begin{array}{l}\text { Timber Mountain Upper Vitric-Tuff Aquifer } \\
\text { (TM-UVTA) }\end{array}$ & WTA, VTA & Includes vitric nonwelded ash-flow and bedded tuff \\
\hline $\begin{array}{l}\text { Timber Mountain Welded-Tuff Aquifer } \\
\text { (TM-WTA) }\end{array}$ & WTA & $\begin{array}{l}\text { Partially to densely welded ash-flow tuff; vitric to } \\
\text { devitrified }\end{array}$ \\
\hline $\begin{array}{l}\text { Timber Mountain Lower Vitric-Tuff Aquifer } \\
\text { (TM-LVTA) }\end{array}$ & VTA & Nonwelded ash-flow and bedded tuff; vitric \\
\hline $\begin{array}{l}\text { Upper Tuff Confining Unit } \\
\text { (UTCU) }\end{array}$ & TCU & Zeolitic bedded tuff \\
\hline $\begin{array}{l}\text { Topopah Spring Aquifer } \\
\text { (TSA) }\end{array}$ & WTA & $\begin{array}{l}\text { Welded ash-flow tuff; present only in extreme } \\
\text { southern Yucca Flat }\end{array}$ \\
\hline $\begin{array}{l}\text { Belted Range Aquifer } \\
\text { (BRA) }\end{array}$ & WTA & Welded ash-flow tuff \\
\hline $\begin{array}{l}\text { Belted Range Confining Unit } \\
(\text { BRCU) }\end{array}$ & TCU & Zeolitic bedded tuffs \\
\hline $\begin{array}{l}\text { Pre-Grouse Canyon Tuff Lava-Flow Aquifer } \\
\text { (Pre-Tbg-LFA) }\end{array}$ & LFA & Lava flow \\
\hline $\begin{array}{l}\text { Lower Tuff Confining Unit } \\
\text { (LTCU) }\end{array}$ & TCU & $\begin{array}{l}\text { Zeolitic bedded tuffs with interbedded but less } \\
\text { significant zeolitic, nonwelded to partially welded } \\
\text { ash-flow tuffs }\end{array}$ \\
\hline $\begin{array}{l}\text { Tub Spring Aquifer } \\
\text { (TUBA) }\end{array}$ & WTA & Welded ash-flow tuff \\
\hline $\begin{array}{l}\text { Oak Spring Butte Confining Unit } \\
(\text { OSBCU) }\end{array}$ & TCU & $\begin{array}{l}\text { Zeolitic bedded tuffs with interbedded but less } \\
\text { significant zeolitic, nonwelded to partially welded } \\
\text { ash-flow tuffs }\end{array}$ \\
\hline $\begin{array}{l}\text { Argillic Tuff Confining Unit } \\
\text { (ATCU) }\end{array}$ & TCU & $\begin{array}{l}\text { Includes the argillic, lowermost Tertiary volcanic } \\
\text { units and paleocolluvium that immediately overlie the } \\
\text { pre-Tertiary rocks. }\end{array}$ \\
\hline $\begin{array}{l}\text { Mesozoic Granite Confining Unit } \\
(\mathrm{MGCU})\end{array}$ & GCU & Granodiorite and quartz monzonite \\
\hline Upper Carbonate Aquifer (UCA) & $\mathrm{CA}$ & Limestone \\
\hline $\begin{array}{l}\text { Lower Carbonate Aquifer - Yucca Flat Upper } \\
\text { Thrust Plate (LCA3) }\end{array}$ & $\mathrm{CA}$ & Limestone and dolomite \\
\hline $\begin{array}{l}\text { Lower Clastic Confining Unit - Yucca Flat } \\
\text { Upper Plate (LCCU1) }\end{array}$ & $\mathrm{CCU}$ & Quartzite and siltstone \\
\hline $\begin{array}{l}\text { Upper Clastic Confining Unit } \\
\text { (UCCU) }\end{array}$ & $\mathrm{CCU}$ & Argillite and quartzite \\
\hline $\begin{array}{l}\text { Lower Carbonate Aquifer } \\
\text { (LCA) }\end{array}$ & $\mathrm{CA}$ & Dolomite and limestone; "regional aquifer" \\
\hline $\begin{array}{l}\text { Lower Clastic Confining Unit } \\
(\text { LCCU) }\end{array}$ & $\mathrm{CCU}$ & Quartzite and siltstone; "hydrologic basement" \\
\hline
\end{tabular}

(a) See Table A-3 for description of HGUs.

Note: Adapted from BN, 2006. 
The zeolitic tuff confining units (TCUs) in Yucca Flat have been grouped into three HSUs: the upper tuff confining unit (UTCU), the lower tuff confining unit (LTCU), and the Oak Spring Butte confining unit (OSBCU) (Table A-7). The LTCU and OSBCU are important HSUs in the Yucca Flat region (stratigraphically similar to the LTCU in Frenchman Flat) because they separate the volcanic aquifer units from the underlying regional LCA. Almost all zeolitized tuff units in Yucca Flat are grouped within the LTCU and OSBCU, which comprises mainly zeolitized bedded tuff (ash-fall tuff, with minor reworked tuff). The LTCU and OSBCU are saturated in much of Yucca Flat; however, measured transmissivities are very low.

The LTCU and OSBCU are generally present in the eastern two-thirds of Yucca Flat. It is absent over the major structural highs, where the volcanic rocks have been removed by erosion. Areas where the LTCU and OSBCU are absent include the "Paleozoic bench" in the western portion of the basin. In northern Yucca Flat, the LTCU and OSBCU tend to be confined to the structural subbasins. Outside the subbasins and around the edges of Yucca Flat, the volcanic rocks are thinner and are not zeolitized.

The unaltered volcanic rocks of Yucca Flat are divided into three Timber Mountain HSUs. The hydrogeology of this part of the geologic section is complicated by the presence of one or more ash-flow tuff units that are quite variable in properties both vertically and laterally.

The Timber Mountain Group includes ash-flow tuffs that can be either WTAs or VTAs, depending on the degree of welding (refer to Sections A.2.3.1 and A.2.3.2). In Yucca Flat, these units are generally present in the central portions of the basin. They can be saturated in the deepest structural subbasins.

The AA is confined primarily to the basins of the NTS. However, because the water table in the vicinity is moderately deep, the alluvium is generally unsaturated, except in the deep subbasins of some valleys. These sediments are porous and, thus, have high storage coefficients. Transmissivities may also be high, particularly in the coarser, gravelly beds.

The more recent large-scale extensional faulting in the Yucca Flat area is significant from both hydrologic and containment perspectives because the faults have profoundly affected the hydrogeology of the Tertiary volcanic units by controlling to a large extent their alteration potential and final geometry. In addition, the faults themselves may facilitate flow of high-pressure gases from nearby explosion cavities and of potentially contaminated groundwater from sources in the younger rocks into the underlying regional aquifers. Final geometry of formations may be such that rocks of very different properties are now juxtaposed (i.e., a Paleozoic carbonate scarp).

Water-level Elevation and Groundwater Flow Direction - Water-level data are abundant for Yucca Flat, as a result of more than 30 years of drilling in the area in support of the weapons testing program. However, waterlevel data for the surrounding areas are scarce. These data are listed in the potentiometric data package prepared for the UGTA regional-scale groundwater model (Hale et al., 1995; IT, 1996b) and in the more recent Yucca FlatCAU-specific data reports (Fenelon, 2005; SNJV, 2006b).

The SWL in the Yucca Flat basin is relatively deep, ranging in depth from about $183 \mathrm{~m}(600 \mathrm{ft})$ in extreme western Yucca Flat to more than $580 \mathrm{~m}$ (1,900 ft) in north-central Yucca Flat (Hale et al., 1995; Laczniak et al., 1996). Elevation of the water table in Yucca Flat varies from $1,340 \mathrm{~m}(4,400 \mathrm{ft})$ in the north (western Emigrant Valley) to $730 \mathrm{~m}(2,400 \mathrm{ft}$ ) at the southern end of Yucca Flat (Hale et al., 1995; Laczniak et al., 1996; Fenelon, 2005). Throughout much of the Yucca Flat area, the SWL typically is located within the lower portion of the volcanic section, in the LTCU and OSBCU. Beneath the hills surrounding Yucca Flat, the SWL can be within the Paleozoic-age units, while in the deeper structural subbasins of Yucca Flat, the Timber Mountain Tuff and the lower portion of the alluvium are also saturated.

Water levels measured in wells completed in the AA and volcanic units in the eastern two-thirds of Yucca Flat are typically about $20 \mathrm{~m}$ (70 ft) higher than in wells completed in the LCA (Winograd and Thordarson, 1975; IT, 1996b; Fenelon, 2005; SNJV, 2006b). The hydrogeology of these units suggests that the higher elevation of the water table in the overlying Tertiary rocks is related to the presence of low permeability zeolitized tuffs of the LTCU and OSBCU (aquitard) between the Paleozoic and Tertiary aquifers (SNJV, 2006b). Detailed water-level 
data indicate the existence of a groundwater trough along the axis of the valley. The semi-perched water within the alluvial aquifer and volcanic aquifers eventually moves downward to the carbonate aquifer in the central portion of the valley. Water-level elevations in western Yucca Flat are also well above the regional water level. The hydrology of western Yucca Flat is influenced by the presence of the Mississippian clastic rocks, which directly underlie the carbonate aquifer of the upper plate of the CP thrust (locally present), AA, and volcanic rocks west of the Topgallant fault. This geometry is a contributing factor in the development of higher (semiperched) water levels in this area. The Climax Stock also bears perched water (Walker, 1962; Laczniak et al., 1996) well above the regional water level.

The present structural interpretation for Yucca Flat depicts the LCCU at great depth, except in the northeast corner of the study area. The Zabriskie Quartzite and Wood Canyon Formation, which are both classified as clastic confining units, are exposed in the northern portion of the Halfpint Range. The high structural position of the LCCU there (and in combination with the Climax Stock) may be responsible for the steep hydrologic gradient observed between western Emigrant Valley and Yucca Flat.

Based on the existing data and as interpreted from the UGTA regional-scale groundwater flow model (DOE/NV, 1997), the overall groundwater flow direction in Yucca Flat is to the south and southwest (Hershey and Acheampong, 1997; see Figure A-5). Groundwater ultimately discharges at Franklin Lake Playa to the south and Death Valley to the southwest.

\section{A.2.5.3 Pahute Mesa Underground Test Area}

This section provides descriptions of the geologic and hydrologic settings of the Pahute Mesa UGTA. This summary was compiled from various sources, including Winograd and Thordarson (1975), Byers et al. (1976; 1989), Laczniak et al. (1996), Cole (1997), and BN (2002b). Additional information can be found in these documents. For detailed stratigraphic descriptions, see Sawyer et al. (1994) and Slate et al. (1999).

The Western and Central Pahute Mesa CAUs, encompassing Areas 19 and 20 of the NTS, were the site of 85 underground nuclear tests (DOE/NV, 2000) (see Figure A-6). These detonations were all conducted in vertical emplacement holes (see Table A-5). The Western Pahute Mesa CAU is separated from the Central Pahute Mesa CAU by the Boxcar fault and is distinguished by a relative abundance of tritium (DOE/NV, 1999). For hydrogeologic studies and modeling purposes, these two CAUs are treated together.

Hydrogeologically, these CAUs are considered to be part of a larger region that includes areas both within and outside the boundaries of the NTS, designated as the Pahute Mesa-Oasis Valley (PM-OV) study area. Because most of the underground nuclear tests at Pahute Mesa were conducted near or below the SWL, test-related contaminants are available for transport via a groundwater flow system that may extend to discharge areas in Oasis Valley. So, like the UGTAs of Frenchman Flat and Yucca Flat, a CAU-scale hydrostratigraphic framework model (BN, 2002b) has been developed for the PM-OV study area to support modeling of groundwater flow and contaminant transport for the UGTA Sub-Project (SNJV, 2006c; 2009).

Physiography - Pahute Mesa is a structurally high volcanic plateau in the northwest corner of the NTS (see Figure A-2). Ground-level elevations in the area range from below 1,650 $\mathrm{m}(5,400 \mathrm{ft})$ off the mesa to the north and south, to over 2,135 m (7,000 ft) in eastern Pahute Mesa. Pahute Mesa proper is composed of flattopped buttes and mesas separated by deep canyons. This physiographic feature covers most of NTS Areas 19 and 20, which are the second-most utilized testing real estate at the NTS. Consequently, there are numerous drill holes that provide a substantial amount of subsurface geologic and hydrologic information (Warren et al., 2000a; 2000b; BN, 2002b).

Geology Overview - Borehole and geophysical data from Pahute Mesa indicate the presence of several nested calderas that produced thick sequences of rhyolite tuffs and lavas. The older calderas are buried by ash-flow units produced from younger calderas. Most of eastern Pahute Mesa is capped by the voluminous Ammonia Tanks and Rainier Mesa ash-flow tuff units, which erupted from the Timber Mountain Caldera, located immed-iately to the south of Pahute Mesa (Byers et al., 1976). The western portion is capped by ash-flows of the Thirsty Canyon 
Group from the Black Mountain caldera. A typical geologic cross section for Pahute Mesa is presented in Figure A-9. For a more detailed geologic summary, see Ferguson et al. (1994), Sawyer et al. (1994), Warren et al. (2000b), and BN (2002b).

The most widespread and significant Quaternary and Tertiary (mainly volcanic) units of the Pahute Mesa area are included in Table A-1. Refer to Table A-2 for a list of Mesozoic (granitic), Paleozoic (sedimentary), and Precambrian (sedimentary and metamorphic) stratigraphic units.

Underlying the Tertiary-age volcanic rocks (exclusive of the caldera complexes) are Paleozoic and Proterozoic sedimentary rocks consisting of dolomite, limestone, quartzite, and argillite. During Precambrian and Paleozoic time, as much as 10,000 m (32,800 ft) of these marine sediments were deposited in the NTS region (Cole, 1997). For detailed stratigraphic descriptions of these rocks, see Slate et al. (1999). The only occurrence of Mesozoic age rocks in the Pahute Mesa area is the Gold Meadows Stock, a granitic intrusive mass located at the eastern edge of Pahute Mesa, north of Rainier Mesa (Gibbons et al., 1963; Snyder, 1977).

The Silent Canyon caldera complex (SCCC) lies beneath Pahute Mesa. This complex contains the oldest known calderas within the SWNVF, and is completely buried by volcanic rocks erupted from younger nearby calderas. It was first identified from gravity observations that indicated a deep basin below the topographically high Pahute Mesa. Subsequent drilling on Pahute Mesa indicated that the complex consists of at least two nested calderas, the Grouse Canyon caldera and younger Area 20 caldera (13.6 and 13.1 Ma, respectively) (Sawyer et al., 1994). For more information on the SCCC, see Ferguson et al. (1994), which is a comprehensive study of the caldera complex based on analysis of gravity, seismic refraction, drill hole, and surface geologic data.

Like the SCCC, the Timber Mountain caldera complex (TMCC) consists of two nested calderas: the Rainier Mesa caldera and younger Ammonia Tanks caldera, 11.6 and 11.45 Ma, respectively (Sawyer et al., 1994). However, unlike the SCCC, the TMCC has exceptional topographic expression, consisting of an exposed topographic margin for more than half its circumference and a well exposed central resurgent dome (Timber Mountain, the most conspicuous geologic feature in the western part of the NTS). The complex truncates the older Claim Canyon caldera (12.65 Ma) (Sawyer et al., 1994), which is further to the south. The calderas of the TMCC are the sources for the Rainier Mesa and Ammonia Tanks Tuffs, which form important and extensive stratigraphic units at the NTS and vicinity.

The Black Mountain caldera is a relatively small caldera in the northwest portion of the Pahute Mesa area. It is the youngest caldera in the area, formed as a result of the eruption, $9.4 \mathrm{Ma}$, of tuffs assigned to the Thirsty Canyon Group (Sawyer et al., 1994).

Deep gravity lows and the demonstrated great thickness of tuffs in the Pahute Mesa area suggest the presence of older buried calderas. These calderas would pre-date the Grouse Canyon caldera and, thus, could be the source of some of the pre-Belted Range units.

Structural Setting - The structural setting of the Pahute Mesa area is dominated by the calderas described in the previous paragraphs. Several other structural features are considered to be significant factors in the hydrology, including the Belted Range thrust fault (see Section A.1.3), numerous normal faults related mainly to basin-andrange extension, and transverse faults and structural zones. However, many of these features are buried, and their presence is inferred from drilling and geophysical data. A typical geologic cross section for Pahute Mesa is presented in Figure A-9. For a more detailed geologic summary, see Ferguson et al. (1994); Sawyer et al. (1994); and $\mathrm{BN}(2002 \mathrm{~b})$. 


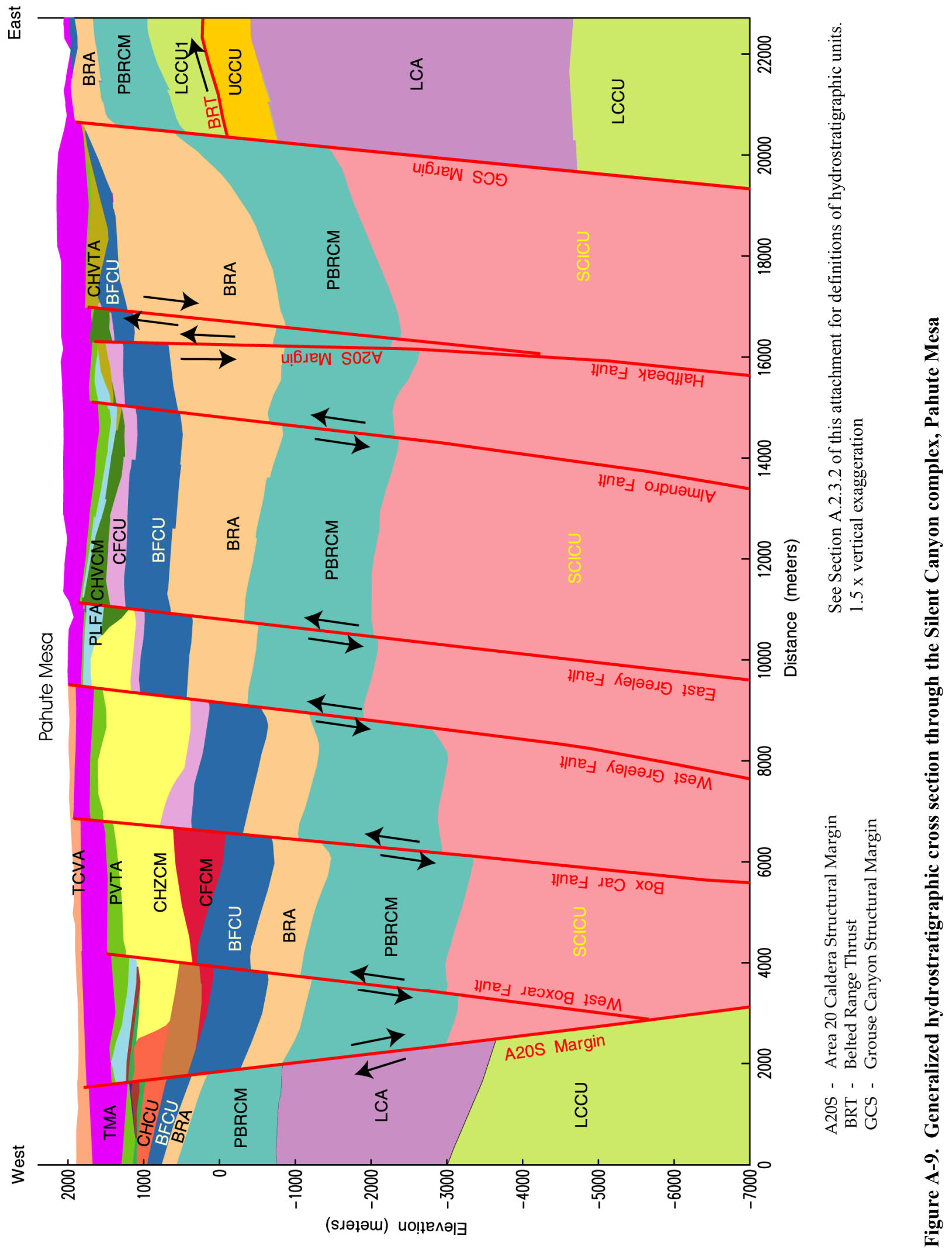


Hydrogeology Overview - The hydrogeology of Pahute Mesa is complex. The thick section of volcanic rocks comprises a wide variety of lithologies that range in hydraulic character from aquifer to aquitard. The presence of several calderas and tectonic faulting further complicate the area, placing the various lithologic units in juxtaposition and blocking or enhancing the flow of groundwater in a variety of ways.

The general hydrogeologic framework for Pahute Mesa and vicinity was established in the early 1970s by U.S. Geological Survey geoscientists (Blankennagel and Weir, 1973; Winograd and Thordarson, 1975). As described in Section A.2.3, their work has provided the foundation for most subsequent hydrogeologic studies at the NTS (IT, 1996a; BN, 2002b).

All the rocks in the PM-OV study area can be classified as one of nine HGUs, which include the AA, four volcanic HGUs, two intrusive units, and two HGUs that represent the pre-Tertiary rocks (see Table A-3).

The rocks within the PM-OV study area are grouped into 44 HSUs for the UGTA CAU-scale hydrogeology framework model (Table A-8; BN, 2002b). The volcanic units are organized into 37 HSUs that include 13 aquifers, 13 confining units, and 11 composite units (comprising a mixture of hydraulically variable units). The underlying pre-Tertiary rocks are divided into six HSUs, including two aquifers and four confining units. HSUs that are common to several CAUs at the NTS are briefly discussed in Section A.2.3.2.

Table A-8. Hydrostratigraphic units of the Pahute Mesa-Oasis Valley area

\begin{tabular}{|c|c|c|}
\hline $\begin{array}{l}\text { Hydrostratigraphic Unit } \\
\text { (Symbol) }\end{array}$ & $\begin{array}{l}\text { Dominant Hydrogeologic } \\
\text { Unit(s) }\end{array}$ & Typical Lithologies \\
\hline Alluvial Aquifer (AA) & AA & Alluvium (gravelly sand); also includes eolian sand \\
\hline $\begin{array}{l}\text { Younger Volcanic Composite Unit } \\
\text { (YVCM) }\end{array}$ & LFA, WTA, VTA & Basalt, welded and nonwelded ash-flow tuff \\
\hline $\begin{array}{l}\text { Thirsty Canyon Volcanic Aquifer } \\
\text { (TCVA) }\end{array}$ & WTA, LFA, lesser VTA & $\begin{array}{l}\text { Partially to densely welded ash-flow tuff; vitric to } \\
\text { devitrified }\end{array}$ \\
\hline $\begin{array}{l}\text { Detached Volcanics Composite Unit } \\
\text { (DVCM) }\end{array}$ & WTA, LFA, TCU & $\begin{array}{l}\text { Complex distribution of welded ash-flow tuff, lava, } \\
\text { and zeolitic bedded tuff }\end{array}$ \\
\hline $\begin{array}{l}\text { Fortymile Canyon Composite Unit } \\
\text { (FCCM) }\end{array}$ & LFA, TCU, lesser WTA & Lava flows and associated tuffs \\
\hline $\begin{array}{l}\text { Timber Mountain Composite Unit } \\
(\mathrm{TMCM})\end{array}$ & $\begin{array}{l}\text { TCU (altered tuffs, lavas) and } \\
\text { unaltered WTA and lesser LFA }\end{array}$ & $\begin{array}{l}\text { Densely welded ash-flow tuff; includes lava flows, } \\
\text { and minor debris flows }\end{array}$ \\
\hline $\begin{array}{l}\text { Tannenbaum Hill Lava-Flow Aquifer } \\
\text { (THLFA) }\end{array}$ & LFA & Rhyolitic lava \\
\hline $\begin{array}{l}\text { Tannenbaum Hill Composite Unit } \\
\text { (THCM) }\end{array}$ & Mostly TCU lesser WTA & $\begin{array}{l}\text { Zeolitic tuff and vitric, nonwelded to welded ash- } \\
\text { flow tuffs }\end{array}$ \\
\hline $\begin{array}{l}\text { Timber Mountain Aquifer } \\
\text { (TMA) }\end{array}$ & Mostly WTA, minor VTA & $\begin{array}{l}\text { Partially to densely welded ash-flow tuff; vitric to } \\
\text { devitrified }\end{array}$ \\
\hline $\begin{array}{l}\text { Subcaldera Volcanic Confining Unit } \\
\text { (SCVCU) }\end{array}$ & TCU & $\begin{array}{l}\text { Probably highly altered volcanic rocks and intruded } \\
\text { sedimentary rocks beneath each caldera }\end{array}$ \\
\hline $\begin{array}{l}\text { Fluorspar Canyon Confining Unit } \\
\text { (FCCU) }\end{array}$ & TCU & Zeolitic bedded tuff \\
\hline Windy Wash Aquifer (WWA) & LFA & Rhyolitic lava \\
\hline $\begin{array}{l}\text { Paintbrush Composite Unit } \\
\text { (PCM) }\end{array}$ & WTA, LFA, TCU & $\begin{array}{l}\text { Welded ash-flow tuffs, rhyolitic lava and minor } \\
\text { associated bedded tuffs }\end{array}$ \\
\hline Paintbrush Vitric-tuff Aquifer (PVTA) & VTA & Vitric, nonwelded and bedded tuff \\
\hline Benham Aquifer (BA) & LFA & Rhyolitic lava \\
\hline
\end{tabular}


Table A-8. Hydrostratigraphic units of the Pahute Mesa-Oasis Valley area (continued)

\begin{tabular}{|c|c|c|}
\hline $\begin{array}{l}\text { Hydrostratigraphic Unit } \\
\text { (Symbol) }\end{array}$ & $\begin{array}{l}\text { Dominant Hydrogeologic } \\
\text { Unit(s) }\end{array}$ & Typical Lithologies \\
\hline $\begin{array}{l}\text { Upper Paintbrush Confining Unit } \\
\text { (UPCU) }\end{array}$ & TCU & Zeolitic, nonwelded and bedded tuff \\
\hline Tiva Canyon Aquifer (TCA) & WTA & Welded ash-flow tuff \\
\hline $\begin{array}{l}\text { Paintbrush Lava-Flow Aquifer } \\
\text { (PLFA) }\end{array}$ & LFA & Lava; moderately to densely welded ash-flow tuff \\
\hline $\begin{array}{l}\text { Lower Paintbrush Confining Unit } \\
\text { (LPCU) }\end{array}$ & TCU & Zeolitic nonwelded and bedded tuff \\
\hline $\begin{array}{l}\text { Topopah Spring Aquifer } \\
\text { (TSA) }\end{array}$ & WTA & Welded ash-flow tuff \\
\hline $\begin{array}{l}\text { Yucca Mountain Crater Flat Composite Unit } \\
\text { (YMCFCM) }\end{array}$ & LFA, WTA, TCU & Lava; welded ash-flow tuff; zeolitic, bedded tuff \\
\hline $\begin{array}{l}\text { Calico Hills Vitric-tuff Aquifer } \\
\text { (CHVTA) }\end{array}$ & VTA & Vitric, nonwelded tuff \\
\hline $\begin{array}{l}\text { Calico Hills Vitric Composite Unit } \\
\text { (CHVCM) }\end{array}$ & VTA, LFA & $\begin{array}{l}\text { Partially to densely welded ash-flow tuff; vitric to } \\
\text { devitrified }\end{array}$ \\
\hline $\begin{array}{l}\text { Calico Hills Zeolitized } \\
\text { Composite Unit (CHZCM) }\end{array}$ & LFA, TCU & Rhyolitic lava and zeolitic nonwelded tuff \\
\hline $\begin{array}{l}\text { Calico Hills Confining Unit } \\
\text { (CHCU) }\end{array}$ & Mostly TCU, minor LFA & Zeolitic nonwelded tuff; minor lava \\
\hline $\begin{array}{l}\text { Inlet Aquifer } \\
\text { (IA) }\end{array}$ & LFA & Lava \\
\hline $\begin{array}{l}\text { Crater Flat Composite Unit } \\
(\mathrm{CFCM})\end{array}$ & $\begin{array}{l}\text { Mostly LFA, intercalated with } \\
\text { TCU }\end{array}$ & Lava and welded ash-flow tuff \\
\hline $\begin{array}{l}\text { Crater Flat Confining Unit } \\
\text { (CFCU) }\end{array}$ & TCU & Zeolitic nonwelded and bedded tuff \\
\hline $\begin{array}{l}\text { Kearsarge Aquifer } \\
\text { (KA) }\end{array}$ & LFA & Lava \\
\hline $\begin{array}{l}\text { Bullfrog Confining Unit } \\
\text { (BFCU) }\end{array}$ & TCU & Zeolitic, nonwelded tuff \\
\hline $\begin{array}{l}\text { Belted Range Aquifer } \\
\text { (BRA) }\end{array}$ & $\begin{array}{l}\text { LFA and WTA, with lesser } \\
\text { TCU }\end{array}$ & Lava and welded ash-flow tuff \\
\hline $\begin{array}{l}\text { Pre-Belted Range Composite Unit } \\
\text { (PBRCM) }\end{array}$ & TCU, WTA, LFA & $\begin{array}{l}\text { Zeolitic bedded tuffs with interbedded but less } \\
\text { significant zeolitic, nonwelded to partially welded } \\
\text { ash-flow tuffs }\end{array}$ \\
\hline $\begin{array}{l}\text { Black Mountain Intrusive Confining Unit } \\
\text { (BMICU) }\end{array}$ & IICU & \multirow{6}{*}{$\begin{array}{l}\text { These units are presumed to be present beneath the } \\
\text { calderas of the SWNVF. Their actual character is } \\
\text { unknown, but they may be igneous intrusive rocks } \\
\text { or older volcanic and pre-Tertiary sedimentary rocks } \\
\text { intruded to varying degrees by igneous rocks. }\end{array}$} \\
\hline $\begin{array}{l}\text { Ammonia Tanks Intrusive Confining Unit } \\
\text { (ATICU) }\end{array}$ & IICU & \\
\hline $\begin{array}{l}\text { Rainier Mesa Intrusive Confining Unit } \\
\text { (RMICU) }\end{array}$ & IICU & \\
\hline $\begin{array}{l}\text { Claim Canyon Intrusive Confining Unit } \\
\text { (CCICU) }\end{array}$ & IICU & \\
\hline $\begin{array}{l}\text { Calico Hills Intrusive Confining Unit } \\
\text { (CHICU) }\end{array}$ & IICU & \\
\hline $\begin{array}{l}\text { Silent Canyon Intrusive Confining Unit } \\
\text { (SCICU) }\end{array}$ & IICU & \\
\hline
\end{tabular}


Table A-8. Hydrostratigraphic units of the Pahute Mesa-Oasis Valley area (continued)

\begin{tabular}{|l|l|l||}
\hline $\begin{array}{l}\text { Hydrostratigraphic Unit } \\
\text { (Symbol) }\end{array}$ & \multicolumn{1}{|c||}{$\begin{array}{c}\text { Dominant Hydrogeologic } \\
\text { Unit(s) }\end{array}$} & \multicolumn{1}{c||}{ Typical Lithologies } \\
\hline $\begin{array}{l}\text { Mesozoic Granite Confining Unit } \\
\text { (MGCU) }\end{array}$ & GCU & $\begin{array}{l}\text { Granodiorite and quartz monzonite; Gold Meadows } \\
\text { Stock }\end{array}$ \\
\hline $\begin{array}{l}\text { Lower Carbonate Aquifer-Thrust Plate } \\
\text { (LCA3) }\end{array}$ & CA & Limestone and dolomite \\
\hline $\begin{array}{l}\text { Lower Clastic Confining Unit Thrust Plate } \\
\text { (LCCU1) }\end{array}$ & CCU & Auartzite and siltstone \\
\hline $\begin{array}{l}\text { Upper Clastic Confining Unit } \\
\text { (UCCU) }\end{array}$ & CCU & Dolomite and limestone; "regional aquifer" \\
\hline $\begin{array}{l}\text { Lower Carbonate Aquifer } \\
\text { (LCA) }\end{array}$ & CA & Quartzite and siltstone; "hydrologic basement" \\
\hline $\begin{array}{l}\text { Lower Clastic Confining Unit } \\
\text { (LCCU) }\end{array}$ & CCU & \\
\hline
\end{tabular}

(a) See Table A-3 for definitions of HGUs.

Note: Adapted from BN, 2002c.

Water-level Elevation and Groundwater Flow Direction - Water-level data are relatively abundant for the Pahute Mesa UGTA as a result of more than 30 years of drilling in the area in support of the weapons testing program. However, water-level data for the outlying areas to the west and south are sparse. These data are listed in the potentiometric data package prepared for the UGTA regional-scale groundwater flow model (IT, 1996b), the Pahute Mesa water table map (O'Hagan and Laczniak, 1996), and recent work in support of flow modeling (SNJV, 2004b; 2006c).

The SWL at Pahute Mesa is relatively deep, at about $640 \mathrm{~m}(2,100 \mathrm{ft})$ below the ground surface. Groundwater flow at Pahute Mesa is driven by recharge in the east and subsurface inflow from the north. Local groundwater flow is influenced by the discontinuous nature of the volcanic aquifers and the resultant geometry created by overlapping caldera complexes and high-angle basin and range faults (Laczniak et al., 1996). Potentiometric data indicate that groundwater flow direction is to the southwest toward discharge areas in Oasis Valley and, ultimately, Death Valley (see Figure A-5).

\section{A.2.5.4 Rainier Mesa/Shoshone Mountain}

The Rainier Mesa/Shoshone Mountain CAU consists of 61 CASs on Rainier Mesa and 6 CASs on Shoshone Mountain, which are located in NTS Areas 12 and 16, respectively (see Figure A-6). Together, these two mesas constitute the third major area utilized for underground testing of nuclear weapons at the NTS between 1957 and 1992. Underground nuclear tests were conducted in horizontal, mined tunnels within these mesas, and two tests were conducted in vertical drill holes. All tests were conducted above the regional water table. Underground geologic mapping data from the six large and several smaller tunnel complexes, and lithologic and geophysical data from dozens of exploratory drill holes, provide a wealth of geologic and hydrologic information for this relatively small underground test area.

Physiography - The Rainier Mesa underground test area includes Rainier Mesa proper and the contiguous Aqueduct Mesa. Rainier Mesa and Aqueduct Mesa form the southern extension of the northeast trending Belted Range (see Figure A-2). This high volcanic plateau cuts diagonally across Area 12 in the north-central portion of the NTS. Ground-level elevations on Rainier Mesa are generally over 2,225 m (7,300 ft). The highest point on the NTS, 2,341 m(7,679 ft), is on Rainier Mesa. Aqueduct Mesa has slightly rougher and lower terrain, generally above $1,920 \mathrm{~m}(6,300 \mathrm{ft})$ in elevation. The edge of the mesas drop off quite spectacularly on the west, south, and east sides.

Shoshone Mountain is located about $20 \mathrm{~km}(12 \mathrm{mi})$ south of Rainier Mesa. It is located in the middle of the NTS, at the west end of Syncline Ridge (see Figures A-2 and A-6). Ground-level elevations range from 1,707 to 2,012 m 
(5,600 to 6,600 ft), but are generally above $1,830 \mathrm{~m}$ (6,000 ft). Tippipah Point, above the old Area 16 tunnels, has an elevation of $2,015 \mathrm{~m}(6,612 \mathrm{ft})$.

Geology Overview - Both Rainer Mesa and Aqueduct Mesa are composed of Miocene-age ash-fall and ash-flow tuffs that erupted from nearby calderas to the west and southwest (NSTec, 2007). As in Yucca Flat, these silicic volcanic tuffs were deposited unconformably on an irregular pre-Tertiary (upper Precambrian and Paleozoic) surface of sedimentary rocks (Gibbons et al., 1963; Orkild, 1963) and Mesozoic granitic rocks (at Rainier Mesa only). The stratigraphic units and lithologies are similar to those present in the subsurface of Yucca Flat (see Section A.2.5.2). The tunnel complexes used for underground nuclear testing at Rainier Mesa and Shoshone Mountain were mined in zeolitized bedded tuff, though the upper part of this section is unaltered (vitric) in some areas. At both locations, the bedded tuffs are capped by a thick layer of welded ash-flow tuff. The Tertiary stratigraphic units and lithologies are similar to those present in the subsurface of Yucca Flat (see Section A.2.5.2).

Structural Setting - The geologic structure of the volcanic rocks of the Rainier Mesa is well documented. Several high-angle, normal faults have been mapped in the volcanic rocks. Faults with greater than about $30 \mathrm{~m}$ $(100 \mathrm{ft})$ of displacement are notably absent in the volcanic rocks of Rainier Mesa. The Rainier and Aqueduct Mesa area was minimally extended during Basin and Range tectonism, thus accounting for the absence of larger faults and its relatively high elevation (NSTec, 2007). At Shoshone Mountain several faults have been mapped, but in general the structure is less well known there than at Rainier Mesa. The structure of the pre-Tertiary section at both locations is poorly known, though some workers speculate that the trace of the Belted Range thrust fault is present in the pre-Tertiary rocks beneath Rainier Mesa. A broad synclinal feature mapped at the surface and in the tuffs of Rainier Mesa and Aqueduct mesas roughly overlies the postulated location of the Belted Range thrust fault. It may reflect a paleo-topographic low or valley beneath the tuffs (Figure A-10), but the exact character of this feature is unknown.

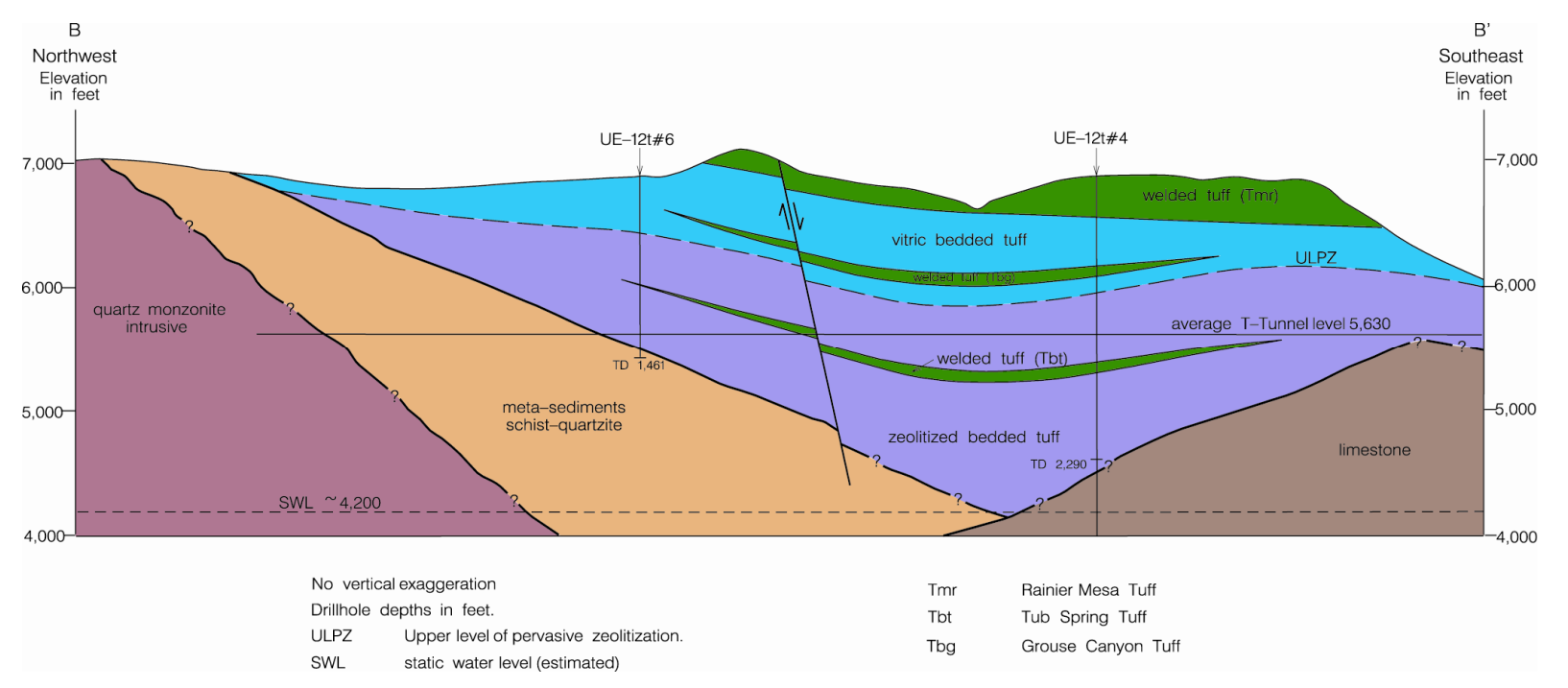

Figure A-10. Generalized hydrostratigraphic cross section through Aqueduct Mesa

Hydrogeology Overview - Construction of UGTA CAU-scale hydrogeology model for the Rainier Mesa and Shoshone Mountain UGTAs was completed in 2007 (NSTec, 2007). All the rocks in the Rainier Mesa-Shoshone Mountain (RM-SM) study area can be classified as one of nine HGUs, which include the AA, four volcanic HGUs, two intrusive units, and two HGUs that represent the pre-Tertiary rocks (see Table A-3). The geologic units within the RM-SM model area are grouped into 44 HSUs (NSTec, 2007). There are 30 Tertiary-age HSUs, including the Tertiary/Quaternary alluvium, older paleocolluvium, two caldera-related collapse breccias, five caldera-related intrusives, one Mesozoic intrusive HSU, and six Paleozoic/Precambrian HSUs. HSUs identified in the RM-SM CAU are listed in Table A-9). 
The hydrostratigraphy for the Tertiary-age volcanic rocks in the former UGTAs (Rainier Mesa, Aqueduct Mesa, and Shoshone Mountain) can be simplified into two categories: zeolitic, tuff confining units and (nonzeolitic) volcanic aquifers. Except for a few nomenclature complications due to embedded welded tuff aquifers, the TCUs belong to either the LTCU or the OSBCU HSU (similar to the hydrostratigraphic section in Yucca Flat, see Subsection A.2.5.2). The LTCU and OSBCU are important HSUs as they separate the UGTs from the underlying regional aquifer.

The hydrostratigraphy of the pre-Tertiary section at Shoshone Mountain is surmised from a single deep drill hole, Well ER-16-1 (U.S. Department of Energy, National Nuclear Security Administration Nevada Site Office [NNSA/NSO], 2006a), and from surficial geology (Orkild, 1963). From oldest to youngest, the hydrogeologic section for the Shoshone Mountain UGTA consists of the regional carbonate aquifer, the upper clastic confining unit, tuff confining units, vitric-tuff aquifers, and welded-tuff aquifers at the surface (Figure A-11). At Rainier Mesa, granitic rocks (granite confining unit [GCU], related to the nearby Gold Meadows Stock), carbonate rocks (carbonate aquifer [CA]), silicic sedimentary rocks such as siltstone, and metamorphic rocks such as quartzite and schist (clastic confining units [CCUs]) have been encountered beneath the tuff section in the few existing drill holes that penetrate through the tuff section. This variability is indicative of the complex geology of the preTertiary section, which is a consequence of the Gold Meadows intrusive and the Belted Range thrust fault.

Most of the tests in Shoshone Mountain and Rainier Mesa tunnels were conducted in the tuff confining unit, though a few were conducted in vitric bedded tuff higher in the stratigraphic section.

Table A-9. Hydrostratigraphic units of the Rainier Mesa-Shoshone Mountain area

\begin{tabular}{|c|c|c|}
\hline $\begin{array}{l}\text { Hydrostratigraphic Unit } \\
\text { (Symbol) }\end{array}$ & $\begin{array}{c}\text { Dominant } \\
\text { Hydrogeologic } \\
\text { Units }^{(a)}\end{array}$ & Typical Lithologies \\
\hline Alluvial aquifer (AA) & AA & $\begin{array}{l}\text { Alluvium: Gravelly sand; also includes colluvium and older } \\
\text { moat-filling sediments around the Timber Mountain caldera }\end{array}$ \\
\hline $\begin{array}{l}\text { Fortymile Canyon Composite Unit } \\
\text { (FCCM) }\end{array}$ & LFA, TCU, lesser WTA & Lava flows, lesser ash-flow and bedded tuffs \\
\hline $\begin{array}{l}\text { Timber Mountain Upper Vitric-Tuff } \\
\text { Aquifer (TM-UVTA) }\end{array}$ & $\begin{array}{l}\text { VTA, } \\
\text { minor WTA }\end{array}$ & $\begin{array}{l}\text { Includes vitric nonwelded to partially welded ash-flow and } \\
\text { bedded tuff }\end{array}$ \\
\hline $\begin{array}{l}\text { Timber Mountain Welded-Tuff Aquifer } \\
\text { (TM-WTA) }\end{array}$ & $\begin{array}{l}\text { WTA } \\
\text { minor VTA }\end{array}$ & $\begin{array}{l}\text { Partially to densely welded ash-flow tuff; vitric to devitrified, } \\
\text { minor nonwelded tuff }\end{array}$ \\
\hline $\begin{array}{l}\text { Timber Mountain Lower Vitric-Tuff } \\
\text { Aquifer (TM-LVTA) }\end{array}$ & VTA & Nonwelded ash-flow and bedded tuff; vitric \\
\hline $\begin{array}{l}\text { Timber Mountain Composite Unit } \\
\text { (TMCM) }\end{array}$ & $\begin{array}{l}\text { TCU (altered tuffs, lavas) } \\
\text { and unaltered WTA and } \\
\text { lesser LFA }\end{array}$ & Welded ash-flow tuffs, lava flows \\
\hline $\begin{array}{l}\text { Rainier Mesa Breccia Confining Unit } \\
\text { (RMBCU) }\end{array}$ & $\mathrm{TCU} / \mathrm{AA}$ & Landslide breccias \\
\hline $\begin{array}{l}\text { Subcaldera Volcanic Confining Unit } \\
\text { (SCVCU) }\end{array}$ & TCU & Highly altered pre-Tm volcanic units \\
\hline Tiva Canyon Aquifer (TCA) & WTA & Welded ash-flow tuff \\
\hline Paintbrush Vitric Tuff Aquifer (PVTA) & VTA & Bedded tuff, vitric \\
\hline Upper Tuff Confining Unit (UTCU) & TCU & Zeolitized bedded tuff \\
\hline Topopah Spring Aquifer (TSA) & WTA minor VTA & Welded ash-flow tuff \\
\hline Lower Vitric-Tuff Aquifer (LVTA) & VTA & Nonwelded and bedded tuff; vitric \\
\hline Calico Hills Vitric-Tuff Aquifer (CHVTA) & VTA & Nonwelded and bedded tuff; vitric \\
\hline $\begin{array}{l}\text { Yucca Mountain Calico Hills Lava-Flow } \\
\text { Aquifer (YMCHLFA) }\end{array}$ & LFA & Lava flow \\
\hline
\end{tabular}


Table A-9. Hydrostratigraphic units of the Rainier Mesa-Shoshone Mountain area (continued)

\begin{tabular}{|c|c|c|}
\hline $\begin{array}{l}\text { Hydrostratigraphic Unit } \\
\text { (Symbol) }\end{array}$ & $\begin{array}{c}\text { Dominant } \\
\text { Hydrogeologic } \\
\text { Units }^{(a)}\end{array}$ & Typical Lithologies \\
\hline Kearsarge Aquifer (KA) & LFA & Lava flow \\
\hline Upper Tuff Confining Unit 2 (UTCU2) & TCU & Zeolitized bedded tuff \\
\hline Stockade Wash Aquifer (SWA) & WTA minor VTA & Weakly welded ash-flow tuff \\
\hline Lower Vitric-Tuff Aquifer 2 (LVTA2) & VTA & Nonwelded and bedded tuff; vitric \\
\hline Bullfrog Confining Unit (BFCU) & TCU & Zeolitic nonwelded tuff \\
\hline Upper Tuff Confining Unit 1 (UTCU1) & TCU & Zeolitized bedded tuff \\
\hline Belted Range Aquifer (BRA) & LFA and WTA & Lava and welded ash-flow tuff \\
\hline Lower Vitric Tuff Aquifer 1 (LVTA1) & VTA & Bedded tuff; vitric \\
\hline Belted Range Confining Unit (BRCU) & TCU & Zeolitized bedded tuff \\
\hline Tub Spring Aquifer (TUBA) & WTA & Welded ash-flow tuff \\
\hline $\begin{array}{l}\text { Lower Tuff Confining Unit } \\
\text { (LTCU) }\end{array}$ & TCU & $\begin{array}{l}\text { Zeolitized bedded tuffs with interbedded but less significant } \\
\text { zeolitized, nonwelded to partially welded ash-flow tuffs }\end{array}$ \\
\hline $\begin{array}{l}\text { Oak Spring Butte Confining Unit } \\
\text { (OSBCU) }\end{array}$ & TCU & $\begin{array}{l}\text { Devitrified to zeolitic non- to partially welded tuffs and } \\
\text { intervening bedded tuffs }\end{array}$ \\
\hline Redrock Valley Aquifer (RVA) & WTA & Welded ash-flow tuff, devitrified \\
\hline $\begin{array}{l}\text { Redrock Valley Breccia Confining Unit } \\
(\mathrm{RVBCU})\end{array}$ & TCU/AA & Landslide breccias \\
\hline Lower Tuff Confining Unit 1 (LTCU1) & TCU & Zeolitized bedded tuffs \\
\hline Twin Peaks Aquifer (TPA) & WTA & Welded ash-flow tuff \\
\hline Argillic Tuff Confining Unit (ATCU) & TCU & Argillic bedded tuffs, minor paleocolluvium \\
\hline $\begin{array}{l}\text { Ammonia Tanks Intrusive Confining Unit } \\
\text { (ATICU) }\end{array}$ & IICU & Intrusive (granite?) and altered, older host rocks \\
\hline $\begin{array}{l}\text { Rainier Mesa Intrusive Confining Unit } \\
\text { (RMICU) }\end{array}$ & IICU & Intrusive (granite?) and altered, older host rocks \\
\hline $\begin{array}{l}\text { Calico Hills Intrusive Confining Unit } \\
\text { (CHICU) }\end{array}$ & IICU & Intrusive (granite?) and altered, older host rocks \\
\hline $\begin{array}{l}\text { Silent Canyon Intrusive Confining Unit } \\
\text { (SCICU) }\end{array}$ & IICU & $\begin{array}{l}\text { Highly altered older volcanic rocks and pre-Tertiary } \\
\text { sedimentary rocks and granitic intrusive masses. }\end{array}$ \\
\hline $\begin{array}{l}\text { Redrock Valley Intrusive Confining Unit } \\
\text { (RVICU) }\end{array}$ & IICU & $\begin{array}{l}\text { Highly altered injected/intruded country rock and granitic } \\
\text { material }\end{array}$ \\
\hline $\begin{array}{l}\text { Mesozoic Granite Confining Unit } \\
\text { (MGCU) }\end{array}$ & GCU & Granodiorite and quartz monzonite \\
\hline $\begin{array}{l}\text { Lower Clastic Confining Unit - Upper } \\
\text { Thrust Plate (LCCU1) }\end{array}$ & $\mathrm{CCU}$ & Quartzite and siltstone \\
\hline $\begin{array}{l}\text { Lower Carbonate Aquifer - Upper Thrust } \\
\text { Plate (LCA3) }\end{array}$ & $\mathrm{CA}$ & Limestone and dolomite \\
\hline Upper Carbonate Aquifer (UCA) & $\mathrm{CA}$ & Limestone \\
\hline Upper Clastic Confining Unit (UCCU) & $\mathrm{CCU}$ & Argillite and quartzite \\
\hline Lower Carbonate Aquifer (LCA) & $\mathrm{CA}$ & Dolomite and limestone \\
\hline Lower Clastic Confining Unit (LCCU) & $\mathrm{CCU}$ & Quartzite and siltstone \\
\hline
\end{tabular}

(a) See Table A-3 for definitions of hydrogeologic units.

Note: Adapted from NSTec (2007). 


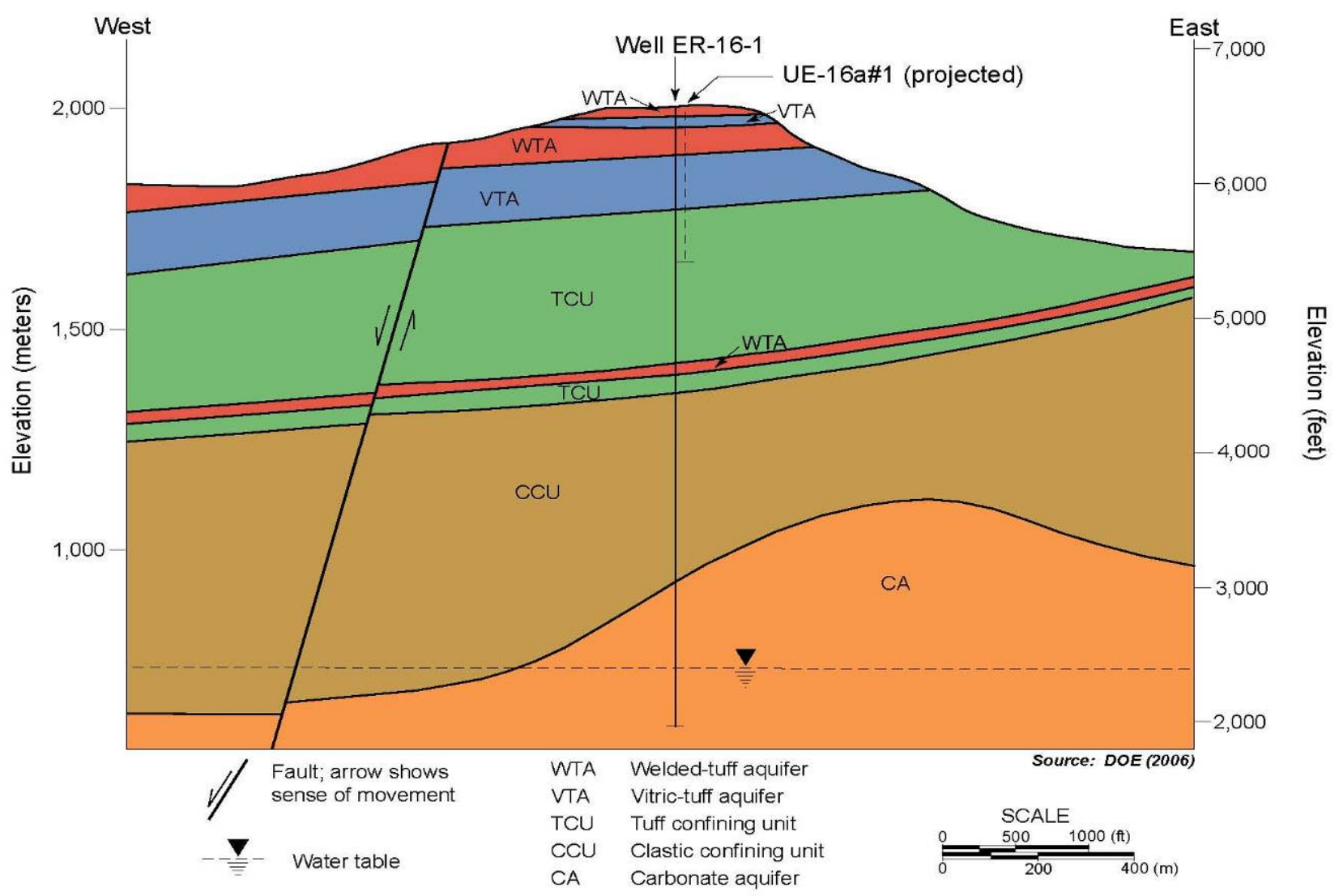

Figure A-11. West-east hydrogeologic cross section through Well ER-16-1

Water-level Elevation and Groundwater Flow Direction - Only a few boreholes on or in the vicinity of Rainier Mesa are deep enough to tag the regional water table. Most notable are UGTA Wells ER-12-3 (NNSA/NSO, 2006b) and ER-12-4 (NNSA/NSO, 2006c) located on Rainier Mesa and Aqueduct Mesa, respectively. The water levels in these wells are $949 \mathrm{~m}(3,114 \mathrm{ft})$ at ER-12-3 and $786 \mathrm{~m}(2,580 \mathrm{ft})$ at ER-12-4, or $1,302 \mathrm{~m}(4,271 \mathrm{ft})$ and $1,312 \mathrm{~m}(4,304 \mathrm{ft})$ elevation, respectively, in the Paleozoic-age carbonate rocks (LCA3) that underlie the volcanic section (Fenelon, 2007). This is approximately $300 \mathrm{~m}(1,000 \mathrm{ft}$ ) below the average elevation of test locations in Rainier Mesa. The SWL, where measured in volcanic units at Rainier Mesa, is at an elevation of about $1,847 \mathrm{~m}(6,060 \mathrm{ft})$. This anomalously high water level relative to the regional water level reflects the presence of water perched above the regional aquifer within the tuff confining unit (Walker, 1962; Laczniak et al., 1996; Fenelon et al., 2008). Water is present in the fracture systems of some of the tunnel complexes at Rainier Mesa. This water currently is permitted to flow from U12e Tunnel (also known as E Tunnel); however, water has filled the open drifts behind barriers built near the portals of U12n and U12t Tunnels.

The water-level at Shoshone Mountain was measured at 1,248 m (4,093 ft) true vertical depth, or $761.7(2,499 \mathrm{ft})$ elevation at UGTA Well ER-16-1 (NNSA/NSO, 2006a) in the Paleozoic-age carbonate rocks (LCA). This is the deepest water level tag at the NTS. No water was encountered during mining at Shoshone Mountain.

Regional groundwater flow from Rainier Mesa may be directed either toward Yucca Flat or, because of the intervening UCCU, to the south toward the Alkali Flat discharge area (Fenelon et al., 2008; see Figure A-5). The groundwater flow direction beneath Shoshone Mountain is probably southward. 


\section{A.2.6 Conclusion}

The hydrogeology of the NTS and vicinity is complex and varied. Yet, the remote location, alluvial and volcanic geology, and deep water table of the NTS provided a favorable setting for conducting and containing underground nuclear tests. Its arid climate and its setting in a region of closed hydrographic basins also are factors in stabilizing residual surficial contamination from atmospheric testing, and are considered positive environmental attributes for existing radioactive waste management sites.

Average groundwater flow velocities at the NTS are generally slow, and flow paths to discharge areas or potential receptors (domestic and public water supply wells) are long. The water tables for local aquifers in the valleys and the underlying regional carbonate aquifer are relatively flat. The zeolitic volcanic formation (TCU) separating the shallower alluvial and volcanic aquifers and the regional carbonate aquifer (LCA) appears to be a viable aquitard. Consequently, both vertical and horizontal flow velocities are low. Additionally, carbon-14 dates for water from NTS aquifers are on the order of 10,000 to 40,000 years old (Rose et al., 1997). Thus, there is considerable residence time in the aquifers, allowing contaminant attenuating processes such as matrix diffusion, sorption, and natural decay to operate.

\section{A.3 Climatology}

The NTS is located in the extreme southwestern corner of the Great Basin. Consequently, the climate is arid, with limited precipitation, low humidity, intense sunlight, and large daily temperature ranges. Meteorological and climatological data are collected on the NTS by the Air Resources Laboratory, Special Operations and Research Division. Data are collected through the Meteorological Data Acquisition (MEDA) system, a network of approximately 30 mobile meteorological towers, which have been located on and near the NTS for many years (see Chapter 16 of the main document, Figure 16-2). The climatological data presented below were developed from the MEDA system.

\section{A.3.1 Precipitation}

Two fundamental physical processes drive precipitation events on the NTS: those resulting from cool-season, mid-tropospheric cyclones and those resulting from summertime convection. Cool-season precipitation is usually light and can consist of rain or snow. Although light, winter precipitation events can last for several days and result in significant precipitation totals per winter storm, especially in January and February. Summer is thunderstorm season. Precipitation from thunderstorms is usually light; however, some storms are associated with very heavy rain, flash floods, intense cloud-to-ground (CG) lightning, and strong surface winds. Thunderstorms generally occur in July and August when moist tropical air can flow from the southeastern North Pacific Ocean and spread over the desert southwest. This seasonal event is referred to as the southwestern monsoon. The winter-summer precipitation mechanisms produce a bimodal monthly precipitation cycle. Figure A-12 shows these patterns of mean monthly precipitation recorded from 6 of the 16 climatological stations on the NTS over the past $40+$ years. Mean annual precipitation totals on the NTS range from nearly 33 centimeters $(\mathrm{cm})$ (13 inches [in.]) over the high terrain in the northwestern part of the NTS to less than $12.7 \mathrm{~cm}$ (5 in.) in Frenchman Flat. However, inter-annual variations can be great. For example, $24.6 \mathrm{~cm}$ (9.67 in.) occurred in Frenchman Flat in 1998 and $68 \mathrm{~cm}$ (26.79 in.) fell on Rainier Mesa in 1978. Annual totals of less than $2.54 \mathrm{~cm}$ (1.0 in.) have occurred on the lower elevations of the NTS. Daily precipitation totals can also be large and can range from 5 to just over $9 \mathrm{~cm}$ (2.0 to over $3.5 \mathrm{in}$.). The greatest daily precipitation event on the NTS was $9.32 \mathrm{~cm}(3.67 \mathrm{in}$.), which was measured in Mid-Valley on October 19-20, 2004. A storm-total precipitation amount of $8.9 \mathrm{~cm}$ (3.5 in.) is a 100-year, 24-hour, extreme precipitation event. Daily totals of 5.1 to $7.6 \mathrm{~cm}$ ( 2 to 3 in.) have been measured at several sites on the NTS (Randerson, 1997).

Snow can fall on the NTS anytime between October and May. In Yucca Flat, the greatest daily snow depth measured is $25.4 \mathrm{~cm}$ (10 in.) in January 1974. The greatest daily depth measured at Desert Rock is $15.2 \mathrm{~cm}(6 \mathrm{in}$.) in February 1987. Maximum daily totals of 38 to $50 \mathrm{~cm}$ (15 to 20 in.) or more can occur on Pahute and Rainier Mesas. Hail, sleet, freezing rain, and fog are rare on the NTS. Only 24 hailstorms were observed in Yucca Flat between 1957 and 1978. Hail and sleet can cover the ground briefly following intense thunderstorms. 

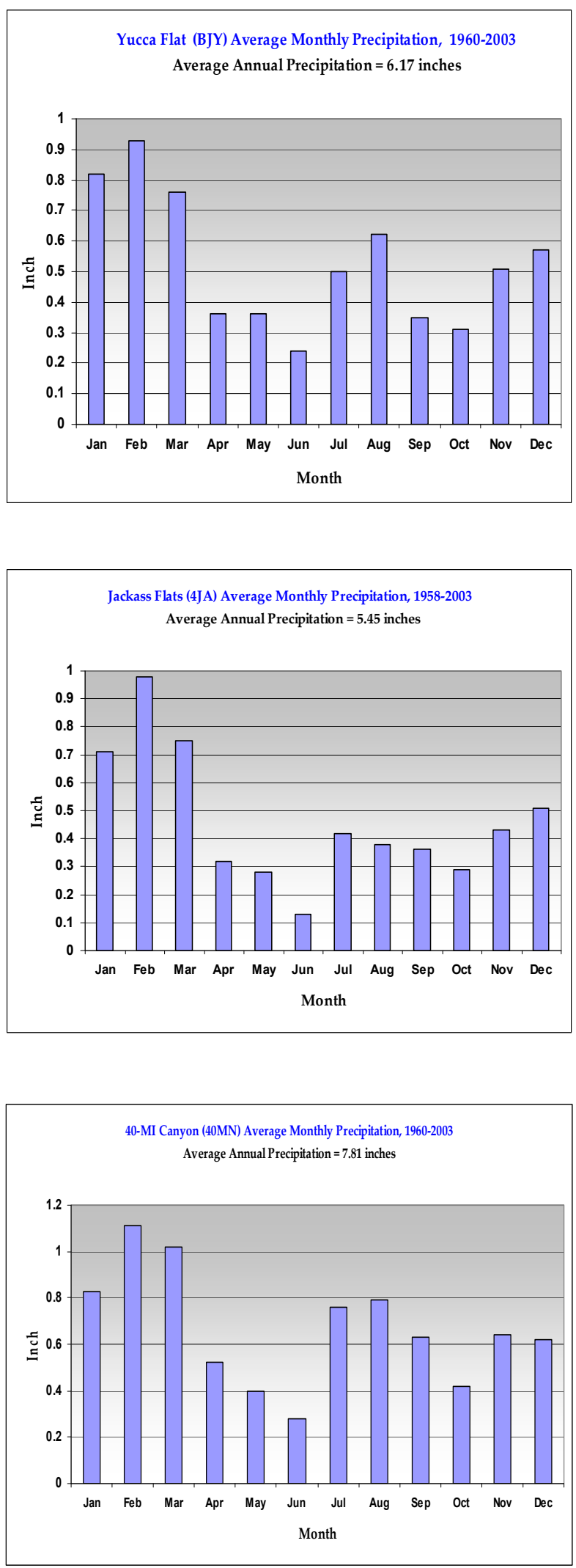
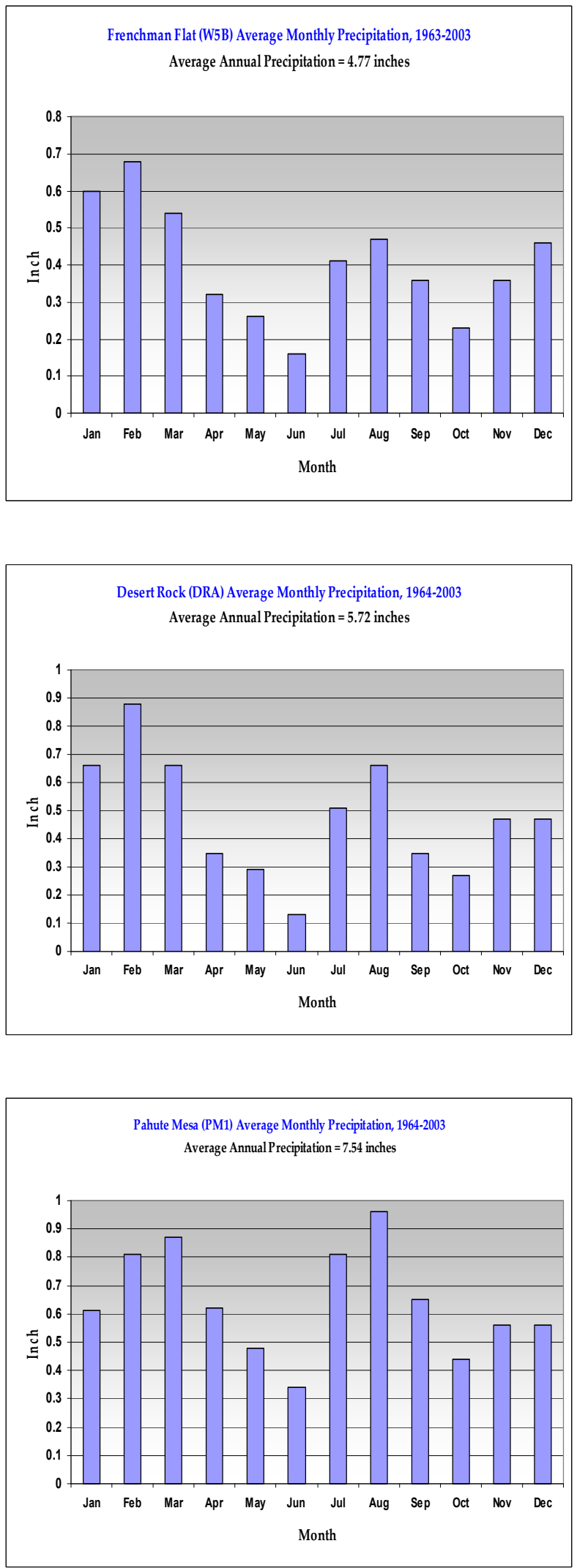

Figure A-12. Mean monthly precipitation at six NTS MEDA stations 


\section{A.3.2 Temperature}

As is typical of an arid climate, the NTS experiences large daily, as well as annual, ranges in temperature. Moreover, temperatures vary with elevation. Sites 1,524 $\mathrm{m}(5,000 \mathrm{ft})$ above mean sea level can be quite cold in the winter and fairly mild during the summer months. At lower elevations, summertime temperatures frequently exceed 37.7 degrees Celcius $\left({ }^{\circ} \mathrm{C}\right)\left(100\right.$ degrees Fahrenheit $\left.\left[{ }^{\circ} \mathrm{F}\right]\right)$. On the dry lakebeds, daily temperature ranges can be 22.2 to $33.3^{\circ} \mathrm{C}\left(40\right.$ to $\left.60^{\circ} \mathrm{F}\right)$ with very cold morning temperatures in the winter and very hot temperatures in the summer. These temperature characteristics are clearly shown in Figure A-13. These annual temperature plots describe the temperature extremes and normal maximums and minimums throughout the year at different locations on the NTS.

In Frenchman Flat, the average daily temperature minimum and maximum for January is -4.4 to $13.3{ }^{\circ} \mathrm{C}(24$ to $\left.56^{\circ} \mathrm{F}\right)$, while in July it is 16.7 to $38.9^{\circ} \mathrm{C}\left(62\right.$ to $\left.102^{\circ} \mathrm{F}\right)$. By contrast, on Pahute Mesa, the minimum and maximum temperature for January is -3.9 to $5^{\circ} \mathrm{C}\left(25\right.$ to $\left.41^{\circ} \mathrm{F}\right)$ and for July, 16.1 to $28.9^{\circ} \mathrm{C}\left(61\right.$ to $\left.84^{\circ} \mathrm{F}\right)$. The highest maximum temperature measured on the NTS is $46.1^{\circ} \mathrm{C}\left(115^{\circ} \mathrm{F}\right)$ in Frenchman Flat near Well 5B in July 1998 and in Jackass Flats near Lathrop Gate in July 2002. The coldest minimum temperature measured on the NTS is $-28.9^{\circ} \mathrm{C}\left(-20^{\circ} \mathrm{F}\right)$ in Area 19 in January 1970 . The temperature extremes at Mercury are -11.7 to $45^{\circ} \mathrm{C}(-11$ to $\left.113^{\circ} \mathrm{F}\right)$.

\section{A.3.3 Wind}

Complex topography, such as that on the NTS, can influence wind speeds and directions. Furthermore, there is a seasonal as well as strong daily periodicity to local wind conditions. For example, in Yucca Flat, during the summer months, the wind direction is usually northerly (from the north) from 10 p.m. Pacific Daylight Time (PDT) to 8 a.m. PDT and southerly from 10 a.m. PDT to 8 p.m. PDT. However, in January, the winds are generally from the north from 6 p.m. Pacific Standard Time (PST) to 11 a.m. PST with some southerly winds developing between 11 a.m. PST and 5 p.m. PST. March through June tend to experience the fastest average wind speeds, 13 to 19 kilometers per hour ( $\mathrm{kmh}$ ) ( 7 to 10 knots or 8 to 12 miles per hour [mph]), with the faster speeds occurring at the higher elevations. Peak wind gusts of 80 to $113 \mathrm{kmh}$ (43 to 61 knots or 50 to $70 \mathrm{mph}$ ) have occurred throughout the NTS. Peak winds at Mercury have been as high as $135 \mathrm{kmh}$ (73 knots or $84 \mathrm{mph}$ ) during a spring wind storm. During the same windstorm, Frenchman Flat experienced wind gusts to $113 \mathrm{kmh}$ (61 knots or $70 \mathrm{mph}$ ). The peak wind speeds measured on the NTS are above $145 \mathrm{kmh}$ (78 knots or $90 \mathrm{mph}$ ) on the high terrain with maximums of $146 \mathrm{kmh}(79 \mathrm{knots}$ or $91 \mathrm{mph})$ at Yucca Mountain Ridge-top, $48 \mathrm{kmh}$ (80 knots or $92 \mathrm{mph}$ ) at the Monastery (MEDA Station 10) in Area 6, and 151 (94 mph) in Area 12 on Radio Hill.

Wind speed and direction data have been summarized for all the meteorological towers (MEDAs) on the NTS. These climatological summaries are referred to as wind roses. Annual wind roses for 16 stations on the NTS for the years 1984 through 2004 are shown in Figure A-14. This figure describes the strong seasonal and diurnal effects on the surface air flow pattern across the NTS. In general, winter and pre-sunrise winds tend to be northerly, while summer and afternoon flow tends to be southerly. Terrain also contributes to determining wind direction.

\section{A.3.4 Relative Humidity}

The air over the NTS tends to be dry. On average, June is the driest month with humidity ranging from 10 percent to 35 percent. Humidity readings of 35 to 70 percent are common in the winter. The reason for this variability is that relative humidity is temperature dependent. The relative humidity tends to be higher with cold temperatures and lower with hot temperatures. Consequently, there is not only a seasonal variation but also a marked diurnal rhythm with this parameter. Early in the morning the humidity ranges from 25 to 70 percent and in mid-afternoon it is in the 10- to 40-percent range, with the larger readings occurring in winter. Humidity readings of more than 75 percent are not common on the NTS. 

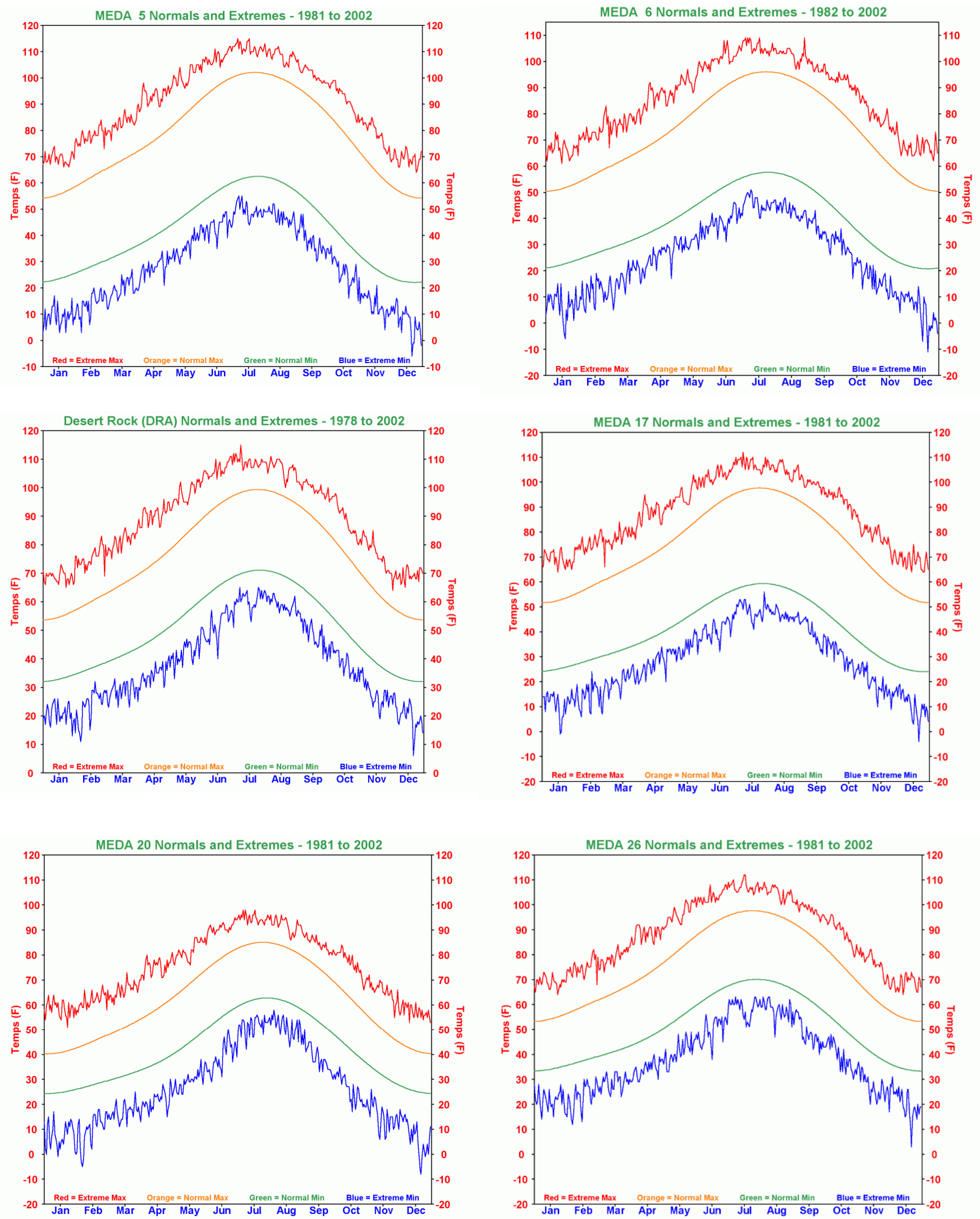

Figure A-13. Temperature extremes and normal maximums and minimums at six NTS MEDA stations (location of numbered stations are shown in Figure A-14) 


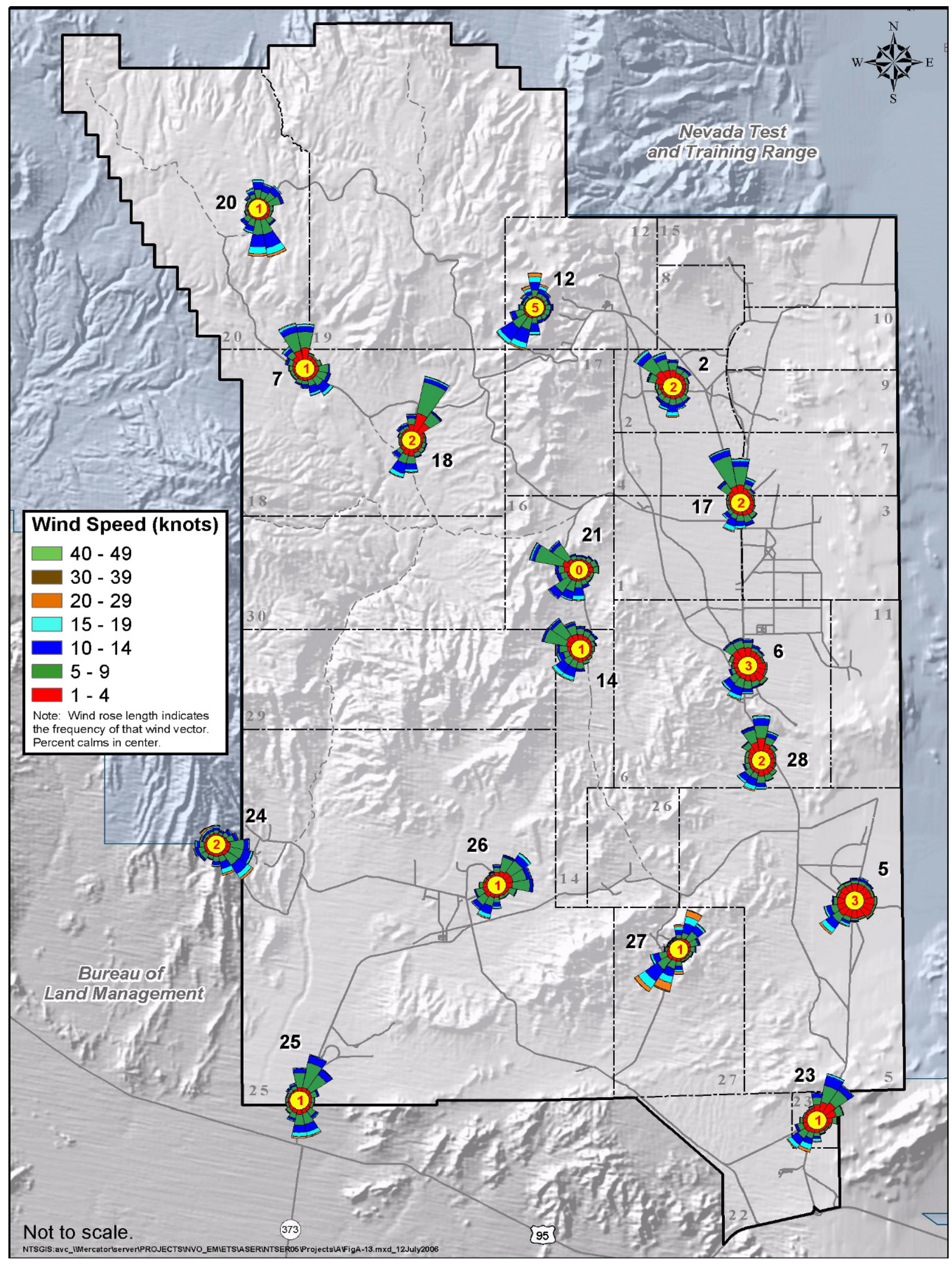

Figure A-14. Twenty-year wind rose climatology for the NTS (1984-2004) 


\section{A.3.5 Atmospheric Pressure}

On the NTS, atmospheric pressure is measured at many of the sites shown in Chapter 16, Figure 16-2. These measurements show that atmospheric pressure has marked annual and diurnal cycles. In addition, pressure decreases with elevation. Consequently, stations at high elevations have lower atmospheric pressures than do stations at lower elevations. Moreover, since pressure depends on temperature, the larger pressure readings occur during the winter months and the smaller readings in the summer months. The diurnal cycle is bimodal and is driven by the diurnal tide of the entire atmosphere and by the diurnal heating/cooling cycle. In general, maximum daily surface pressure on the NTS occurs between 8 and 10 a.m. PST (later in winter, earlier in summer) and minimum pressure tends to occur between 2 and 6 p.m. PST (earlier in winter, later in summer). Weaker secondary maxima occur at approximately midnight PST and minima near 3 a.m. PST. In Yucca Flat (elevation

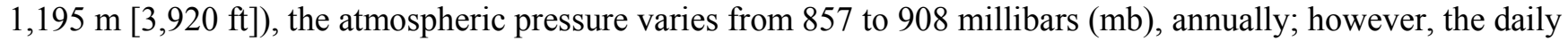
range is only approximately $3.4 \mathrm{mb}$ in summer and $2.7 \mathrm{mb}$ in winter.

A phenomenon referred to as atmospheric or barometric pumping can occur as atmospheric pressure decreases. When this happens, gases trapped below ground can "vent" or seep upward through the soil and enter the atmosphere. Barometric pumping was observed on the NTS following some underground nuclear tests, and small concentrations of noble gases from the tests were detected for several months afterwards. Barometric pumping also contributes to the release of naturally occurring radionuclides (e.g., radon) from terrestrial sources.

\section{A.3.6 Dispersion Stability Categories}

Determination of the stability of the atmosphere near the ground is a key input requirement for atmospheric dispersion models. Such models are used to estimate the impacts of hazardous materials that might be accidentally released into the atmosphere or become airborne from radioactively contaminated soil sites on the NTS. The dispersion models commonly used for this purpose are Gaussian plume models that require the specification of stability categories to account for effects of atmospheric turbulence on the dispersion process. The mountain-valley topography on the NTS makes it impossible to calculate a single set of values that characterizes atmospheric turbulent mixing on the NTS. Consequently, the stability categories for the NTS are calculated from the average hourly wind speeds for each MEDA station, the solar angle, and the hourly cloudcover observations reported at the Desert Rock Meteorological Observatory. This procedure follows regulatory guidance provided by the U.S. Environmental Protection Agency (EPA) (2000) and the American Nuclear Society (2005). The stability category concept makes use of the letters "A" through "F" to define different turbulence regimes. Category " $A$ " specifies free convection in statistically unstable air, "D" represents neutral stability, and "F" is very stable (dispersion suppressed) with little turbulent mixing. In Yucca and Frenchman Flats, in winter, F-stability tends to persist from 4 p.m. PST until 8 a.m. PST the next morning with an abrupt transition to C- or B-stability near 9 a.m. PST, followed by C- or B-stability during the afternoon. In summer, E- or F-stabilities occur between 7 p.m. PST and 6 a.m. the next morning with a rapid change to B-stability at 7 a.m. PST and, generally, C- or B-stabilities and some D-stability in late afternoon.

\section{A.3.7 Other Natural Phenomena}

Wind speeds in excess of $97 \mathrm{kmh}(60 \mathrm{mph})$ occur annually. Additional severe weather in the region includes occasional severe thunderstorms, lightning, hail, and dust storms. Severe thunderstorms may produce high precipitation rates that may create localized flash flooding. Few tornadoes have been observed in the region and are not considered a significant threat.

CG lightning can occur throughout the year but occurs primarily between June and September. Maximum CG lightning activity on the NTS occurs between 1 p.m. and 4 p.m. PDT while minimum activity occurs between 8 a.m. and 9 a.m. PDT. For safety analyses, the mean annual flash density on the NTS is 0.4 flashes per square kilometer. Randerson and Sanders (2002) have characterized CG lightning activity on the NTS. 


\section{A.4 Ecology}

The NTS lies on the transition between the Mojave and Great Basin deserts. As a result, elements of both deserts are found in a diverse and complex flora and fauna (Ostler et al., 2000; Wills and Ostler, 2001).

\section{A.4.1 Flora}

A total of 752 taxa of vascular plants have been collected in ten major vegetation alliances (Figure A-15). A total of 20 vegetation associations from among the alliances have been identified and mapped. Distributions of the Mojave Desert, transition zone, and Great Basin Desert ecoregion vegetation alliances and associations are linked to temperature extremes, precipitation, and soil conditions.

Vegetation associations characteristic of the Mojave Desert occur over the southern third of the NTS, on hillsides and mountain ranges at elevations below about 1,219 $\mathrm{m}$ (4,000 ft) (Figure A-15). Creosote bush (Larrea tridentata) is the dominant shrub within these associations. Creosote bush associations are absent from habitats where the mean minimum air temperature is below $-1.9^{\circ} \mathrm{C}\left(28.5^{\circ} \mathrm{F}\right)$ or the extreme minimum is less than $-17.2^{\circ} \mathrm{C}$ $\left(1^{\circ} \mathrm{F}\right)$. It is also limited to zones with an average rainfall of $18.3 \mathrm{~cm}(7.2 \mathrm{in}$.) or less (Beatley, 1974). Between elevations of 1,219 to $1,524 \mathrm{~m}(4,000$ to $5,000 \mathrm{ft})$, transitional vegetation associations exist. The largest and most important is the Blackbrush-Nevada Jointfir (Coleogyne ramosissima-Ephedra nevadensis) Shrubland Association, which covers 21.6 percent of the total area of the NTS (Ostler et al., 2000). Above 1,524 m $(5,000 \mathrm{ft})$, the vegetation mosaic is characteristic of the Great Basin Desert. Throughout the central and northwestern mountains of the NTS, the dominant shrub species are basin big sagebrush (Artemisia tridentata) and black sagebrush (Artemisia nova). The distribution of Great Basin Desert associations appears to be limited by mean maximum temperature and by minimum rainfall tolerances of the cold desert species (Beatley, 1975).

Above 1,828 m (6,000 ft), singleleaf pinyon (Pinus monophylla) and Utah juniper (Juniperus osteosperma) mix with the sagebrush association where there is suitable moisture for these trees. Tree densities on the NTS are often not high enough to create closed canopies, but rather, form an open woodland type with a mix of shrub and tree cover.

None of the plant species on the NTS are listed as threatened or endangered under the Endangered Species Act. However, 18 vascular plants and 1 non-vascular plant on the NTS are considered to be sensitive by the Nevada Natural Heritage Program (see Chapter 13 of the main document, Table 13-2). Sensitive species are those whose long-term viability has been identified as a concern by natural resource experts. Through past field survey efforts over multiple years, population locations of sensitive species have been mapped on the NTS (Figure A-16) and are monitored under the Ecological Monitoring and Compliance Program (see Chapter 13 of the main document).

\section{A.4.2 Fauna}

At least 1,163 taxa of invertebrates within the phylum Arthropoda have been identified on the NTS. Of the known arthropods, 78 percent are insects. Ants, termites, and ground-dwelling beetles are probably the most important groups of insects in regard to distribution, abundance, and functional roles. No native fish species occur on the NTS, although non-native goldfish (Carassius auratus), golden shiner (Notemigonus crysoleucas), and bluegill (Lepomis machrochirus) have been unofficially introduced into a few man-made ponds. The nonnative bullfrog (Rana catesbeiana) is the only amphibian that is known to occur on the NTS. 


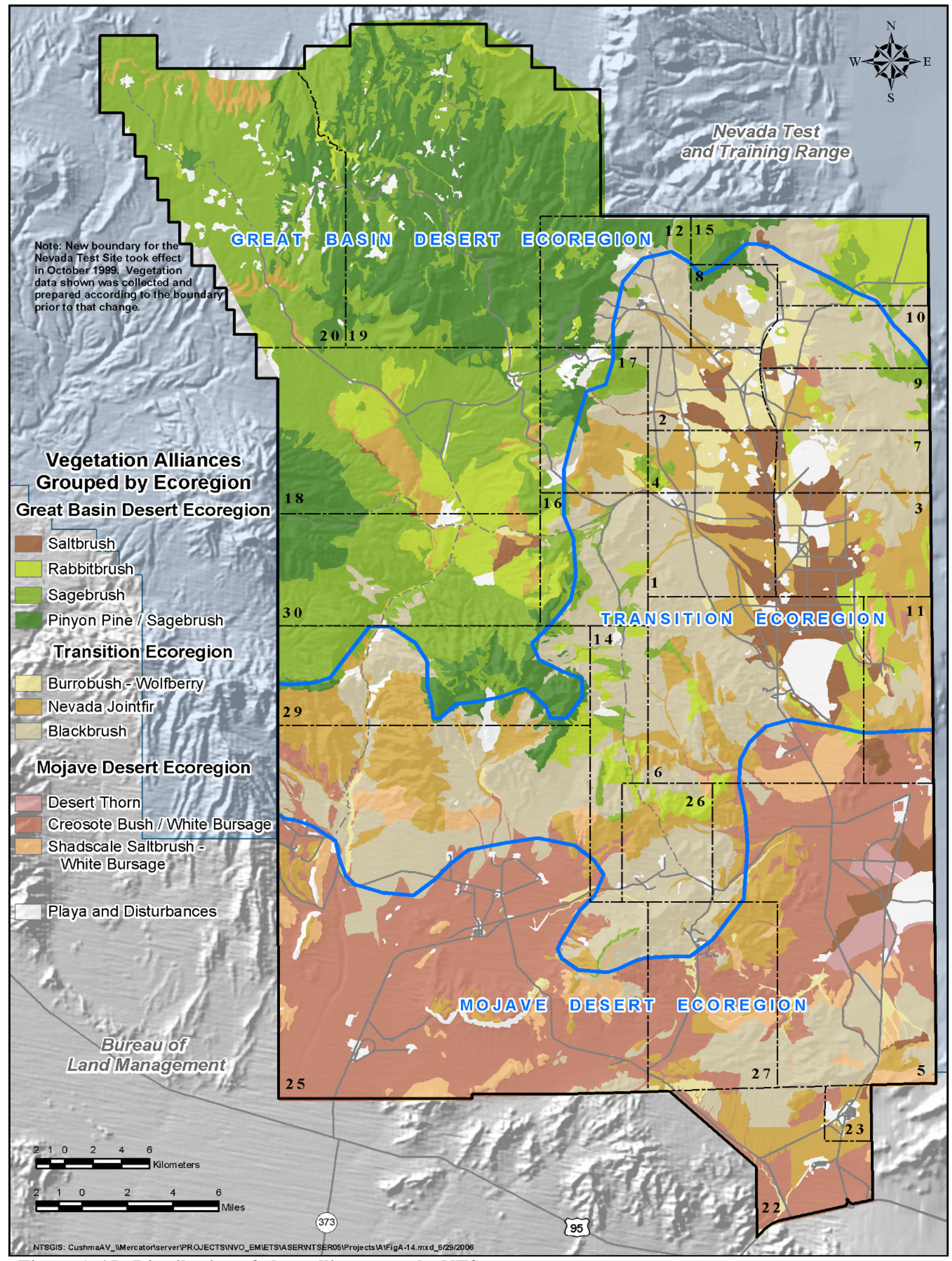

Figure A-15. Distribution of plant alliances on the NTS 


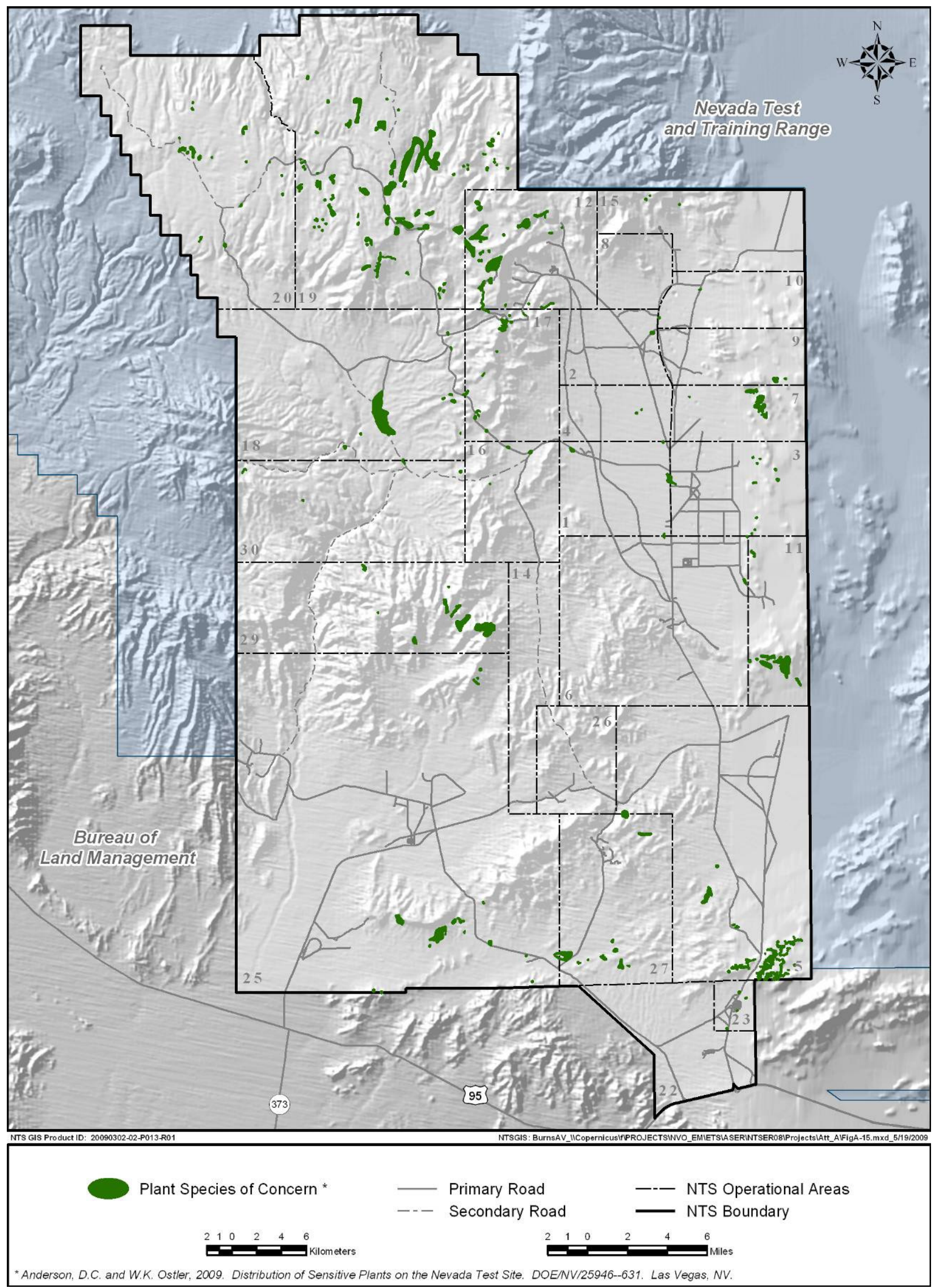

Figure A-16. Known locations of sensitive plant species on the NTS 
Among reptiles, the desert tortoise (Gopherus agassizii), 16 lizard species, and 17 snake species are known to occur on the NTS (Wills and Ostler, 2001). The rich reptile fauna is partly due to the overlapping ranges of plant species characteristic of the Mojave and Great Basin Deserts. The most abundant, widely distributed lizards include the side-blotched lizard (Uta stansburiana), western whiptail (Cnemidophorus tigris), and desert horned lizard (Phrynosoma platyrhinos). The western shovel-nosed snake (Chionactis occipitalis) is the most common snake on the NTS. There are four species of poisonous snakes: the Mohave Desert sidewinder (Crotalus cerastes), Panamint rattlesnake (Crotalus mitchellii), night snake (Hypsiglena torquata), and Sonoran lyre snake (Trimorphodon biscutatus).

There are records of 239 species of birds observed on the NTS (Wills and Ostler, 2001). Approximately 80 percent of the bird species are migrants or seasonal residents. To date, 26 species, including 9 raptor species (birds of prey) are known to breed on the NTS. Raptors that breed on the NTS include the golden eagle (Aquila chrysaetos), long-eared owl (Asia otus), red-tailed hawk (Buteo jamaicensis), Swainson's hawk (Buteo swainsoni), prairie falcon (Falco mexicanus), American kestrel (Falco sparverius), western burrowing owl (Athene cunicularia hypugaea), barn owl (Tyto alba), and great-horned owl (Bubo virginianus) (BN, 2002c).

There are 44 terrestrial mammals and 15 bat species that are known to occur on the NTS. Rodents account for about 40 percent of the known mammals and, in terms of distribution and relative abundance, are the most important group of mammals on the NTS (Wills and Ostler, 2001). There is an apparent correlation between production by winter annual plants and reproduction in desert rodents on the NTS. Larger mammals on the site include black-tailed jackrabbit (Lepus californicus), desert cottontail (Sylvilagus audubonii), feral horse (Equus caballus), mule deer (Odocoileus hemionus), pronghorn antelope (Antilocapra americana), coyote (Canis latrans), kit fox (Vulpes macrotis), grey fox (Urocyon cinereoargenteus), badger (Taxidea taxus), bobcat (Lynx rufus), mountain lion (Puma concolor), burro (Equus asinus), and bighorn sheep (Ovis canadensis). Mule deer herds occur mainly on the high mesas and surrounding bajadas. Small numbers of feral horses and pronghorn antelope range over small areas of the NTS. Bighorn sheep and burros are thought to be rare visitors.

The desert tortoise is the only resident species found on the NTS that is listed as threatened under the Endangered Species Act. Habitat of the desert tortoise is in the southern third of the NTS (see Chapter 13, Figure 13-1). No other federally threatened or endangered animal is known to occur on the NTS. All but three birds on the NTS are protected by federal legislation under the Migratory Bird Treaty Act and/or by the State of Nevada. Most non-rodent mammals of the NTS are protected by the State of Nevada and managed as either game or furbearing mammals, and 12 bats on the NTS are considered sensitive species (see Chapter 13, Tables 13-2 and 13-3).

\section{A.4.3 Natural Water Sources}

Important biological communities on the NTS are those associated with springs or other natural sources of water. They are rare, localized habitats that are important to regional wildlife and to isolated populations of water-loving plants and aquatic organisms. There are 30 natural water sources on the NTS that include 15 springs, 9 seeps, 4 tank sites (natural rock depressions that catch and hold surface runoff), and 2 ephemeral ponds (Hansen et al., 1997; BN, 1998; 1999) (Figure A-17). 


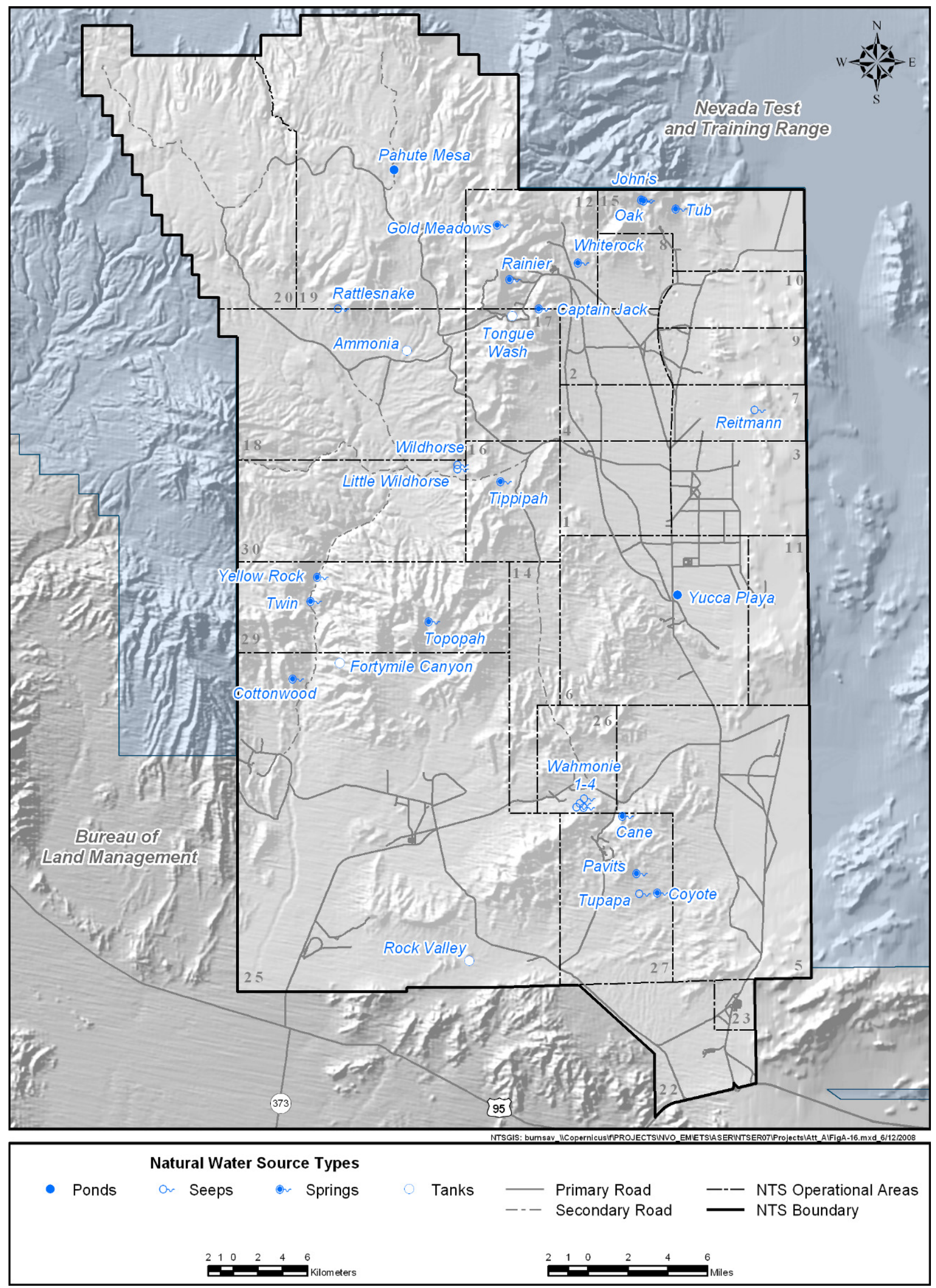

Figure A-17. Natural water sources on the NTS 


\section{A.5 Cultural Resources}

\section{A.5.1 Cultural Resources Investigations on the NTS}

Few cultural resources investigations were performed from the 1940s to the 1960s on what is now the NTS. Earlier explorers did visit the area, such as O. S. Lodwick in the 1900s and Mark R. Harrington of the Heye Museum of the American Indian in the $1920 \mathrm{~s}$, but the visits were brief, and no in-depth studies were attempted. The work conducted by S. M. Wheeler in 1940 is the first serious investigation, resulting in some prominent sites being recorded (Winslow, 1996). Wheeler and a small party, including his wife, supported by the Nevada State Parks Commission, were guided by Roscoe J. Wright, also known as (a.k.a.) "Death Valley Curley," a local miner, into the Fortymile Canyon region with the specific purpose of investigating archaeological sites (Figure A-18). The party spent only a few days in the area and only briefly described the cultural resources they found. In 1955, Richard Shutler (1961), seeking evidence of pueblo ruins, was the next archaeologist to visit and record sites in the same general area of Fortymile Canyon as well as on Timber Mountain. He was guided by Bill Martin, a Shoshone from Beatty. Frederick C. V. Worman $(1965 ; 1966 ; 1967 ; 1969)$, a zoologist and a vocational archaeologist employed by Los Alamos National Laboratory, and Donald Tuohy (1965), an archaeologist from the Nevada State Museum, conducted limited surveys and excavations during the 1960s. These investigations were typically salvage archaeology in response to an Atomic Energy Commission (AEC) directive regarding the preservation and protection of antiquities on AEC lands. It was not until the late 1970s with stronger federal laws and regulations concerning cultural resources that systematic archaeological investigations on the NTS were carried out on a regular basis. Desert Research Institute (DRI) became the cultural resources support contractor at this time, and ever since, has performed numerous surveys and data recovery efforts (Figure A-19), as well as records keeping and curation of artifacts. Lately, historical evaluations of NTS structures and buildings have become part of the program in documenting a significant period in the local and national history regarding nuclear testing and the Cold War era (Figure A-20).

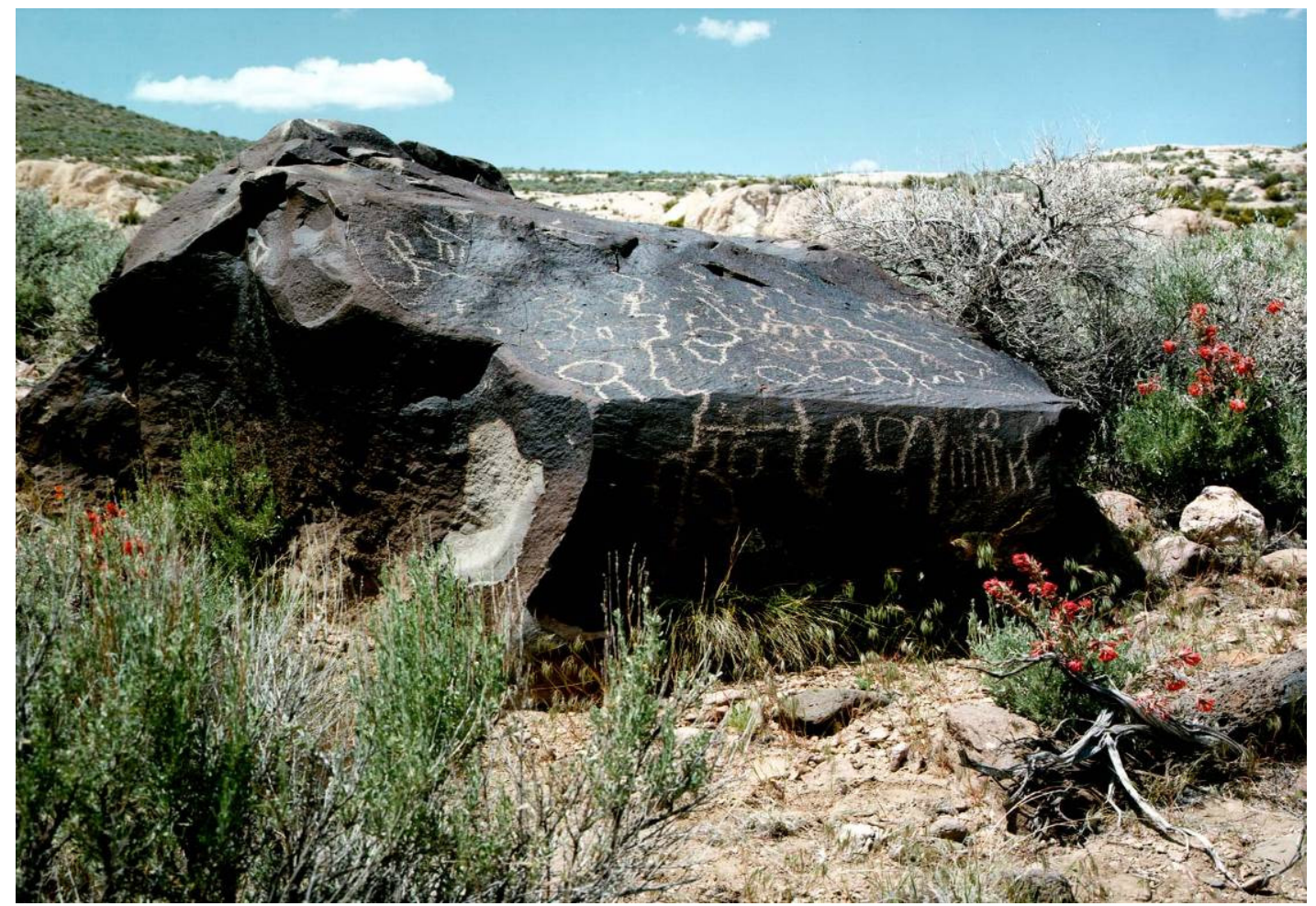

Figure A-18. Example of prehistoric petroglyphs found on the NTS. This rock art site is in Fortymile Canyon (photo taken by DRI, 1996). 


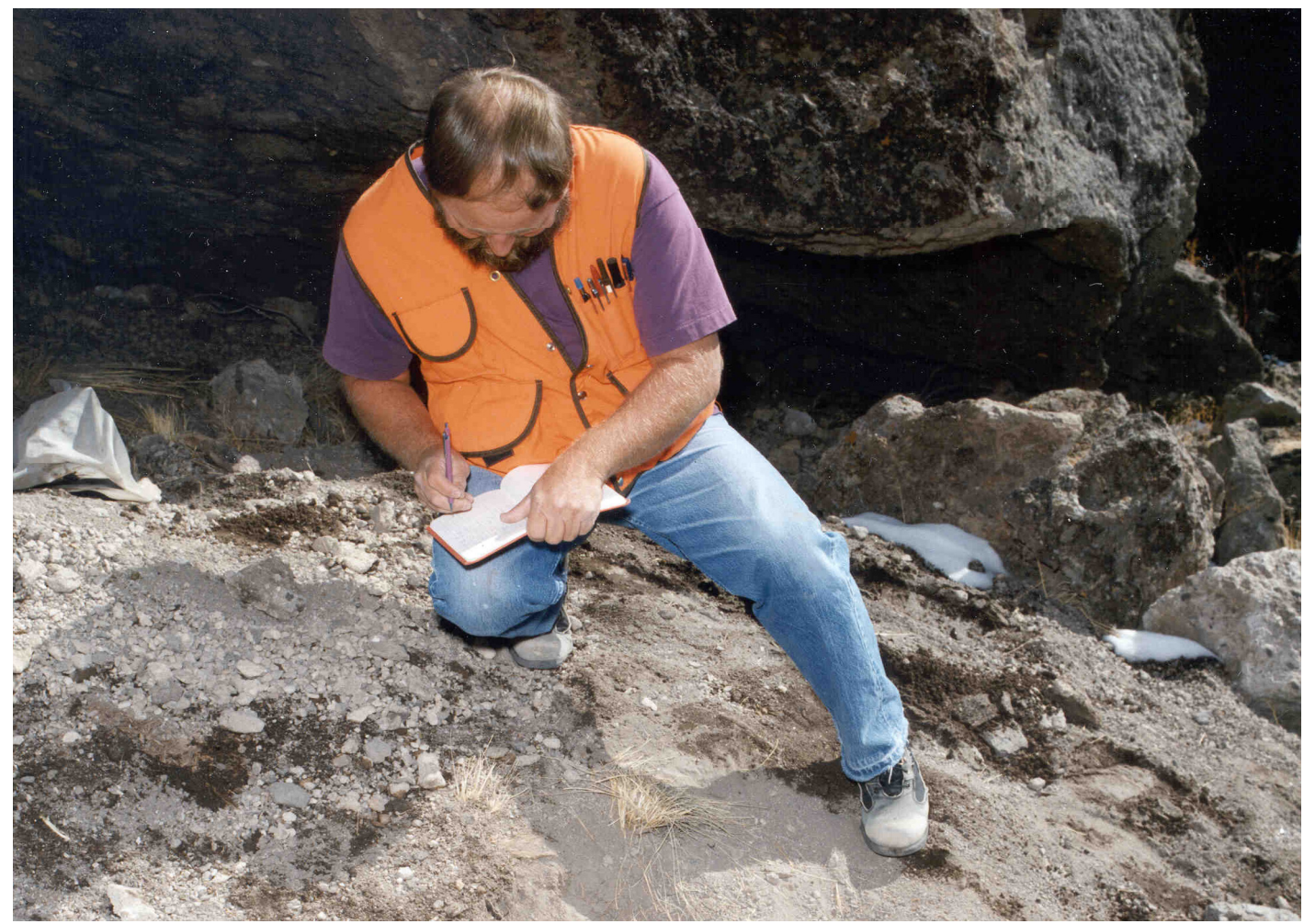

Figure A-19. DRI archaeologist at an archaeological excavation of a prehistoric site on Pahute Mesa. The site is probably from the middle to late Holocene period (photo taken by DRI, 1992).

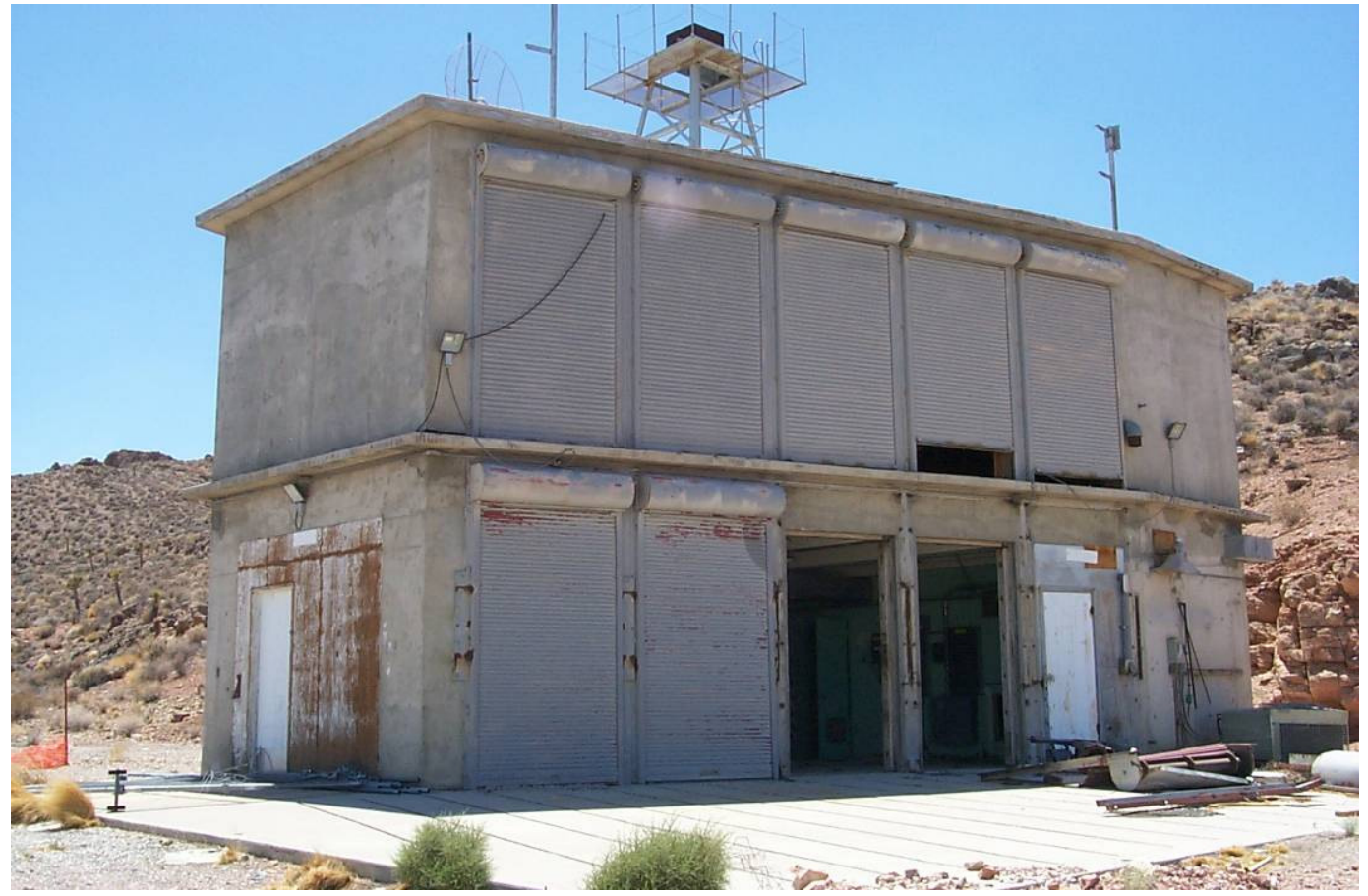

Figure A-20. Building 400, a camera station for photographing atmospheric tests, at Area 6 Control Point, built in 1951. It is one of the first buildings constructed on the NTS to support weapons testing activities (photo taken by DRI, 2003). 


\section{A.5.2 Paleo-Indian Period}

The oldest cultural remains discovered on the NTS are Clovis-style projectile point fragments dating to the Paleo-Indian period, circa (ca.) 12,000 to 10,000 years before present (BP). One was found along an alluvial terrace of Fortymile Wash near Yucca Mountain (Reno, 1985) and a second at the upper reaches of the Fortymile drainage system near Rattlesnake Ridge at the west base of Rainier Mesa (Jones and Edwards, 1994). The basic economic strategy for the Paleo-Indian was hunting of big game and a predominant use of lacustrine-marsh areas around late Pleistocene and early Holocene pluvial lakes (Madsen, 1982; Warren and Crabtree, 1986). Pluvial lakes were a result of cooler temperatures and higher annual precipitation characteristic of this time (Grayson, 1993). No evidence is available, however, to indicate that the basins on the NTS supported pluvial lakes as in other nearby valleys, such as Groom Lake east of the NTS and the Kawich, Gold Flat, and Mud lakes to the north (Grayson, 1993: Table 5-2; Mifflin and Wheat, 1979). The Fortymile Canyon drainage, where the Clovis points were found, may have been used as a travel route between highland and lowland areas or, as proposed by Pippin (1998), part of a hunting territory where certain animals such as deer and elk could be found.

\section{A.5.3 Early Holocene Period}

A general broadening in the types of resources being exploited from a variety of environments occurs during the early Holocene, ca. 10,000 to 7,500 BP, and includes aquatic and small animals as well as plants (Grayson, 1993). Initially, lakes and marshes still abounded overall, but the climate began to change to one more dry, and by $8,000 \mathrm{BP}$ most of the standing bodies of water were gone (Grayson, 1993). Consequently, the woodlands began to move upslope to be replaced by sagebrush or bursage and creosote bush (Grayson, 1993).

Most cultural activities still appear to be restricted to the lower elevations (Haynes, 1996; Reno et al., 1989); however, Pippin (1998) indicates that only short-term hunting forays, originating from the lower elevations, occurred in the higher elevations of the NTS. This is similar to the pattern described for the eastern Great Basin (Madsen, 1982).

\section{A.5.4 Middle Holocene Period}

The period from ca. 7,500 to 4,500 BP is marked by increased aridity, and a hotter and dryer climate compared to the previous episode and to that of today (Antevs, 1948; Miller and Wigand, 1994). Some evidence suggests that entire areas were abandoned. For example, Warren and Crabtree (1986) contend that the people living in the Mojave Desert at this time were ill-adapted to the arid conditions because so few sites have been found; of those sites, they appear to represent short-term activities with low artifact densities indicative of a highly mobile lifestyle. They suggest that the people may have aggregated at the margins of the desert near springs and other dependable water sources and only briefly entered the more arid localities during times of greater effective moisture. Few sites have been found in the Great Basin dating to this period as well. Grayson (1993) indicates that the higher elevation zones were becoming an important part of the subsistence base, and human movements coincide with the upward movement in elevation of the woodlands. Pippin (1998) also notes this change on the NTS, but he sees the cultural response as an intensification and expansion of the areas previously exploited and not in the relocation of residential bases to the uplands.

\section{A.5.5 Late Holocene Period}

The period from ca. 4,500 to 1,900 BP is generally known for cooler and wetter conditions. Subsequent periods fluctuated between dry and wet episodes, with the most notable arid periods from 1,900 to 1,000 BP and 700 to 500 BP (Miller and Wigand, 1994). A pattern of heavy winter precipitation began after 500 BP, but average temperatures have gradually increased since the end of the Little Ice Age about 150 years ago. 
Culturally, there is an increase in the number of sites and a broadening of the subsistence base (Grayson, 1993; Lyneis, 1982). A shift in the settlement pattern is made in some areas of the southern Great Basin to comparatively large, semi-sedentary communities on valley floors accompanied by a more frequent use of the highlands. An increase in the frequency of milling implements indicates a greater reliance on seeds than previously practiced (Warren and Crabtree, 1986). Evidence at higher elevations on the NTS supports the contention that highland resources were an important part of the subsistence base, and, quite likely, logistical seasonal movements between resource zones were being practiced (Pippin, 1998). Rock features interpreted as food caches begin to appear within the woodlands (Pippin, 1998). Examples of projectile points from this period found by DRI archaeologists on the NTS are shown in Figure A-21. One of the most conspicuous technological changes is the introduction of the bow and arrow, ca. 1,500 BP. Madsen (1986a) suggests that the advent of this implement may have led to increased efficiency in hunting to where the animal populations were significantly reduced, resulting in a greater dependence by the people on plant resources, such as pinyon and other seed plants. Another introduction was brownware pottery (Figure A-22), ca. 700 to 1,000 BP (Madsen, 1986b; Pippin, 1986; Lockett and Pippin, 1990; Rhode, 1994), indicating a more sedentary lifestyle and a change in the way food was prepared and stored.

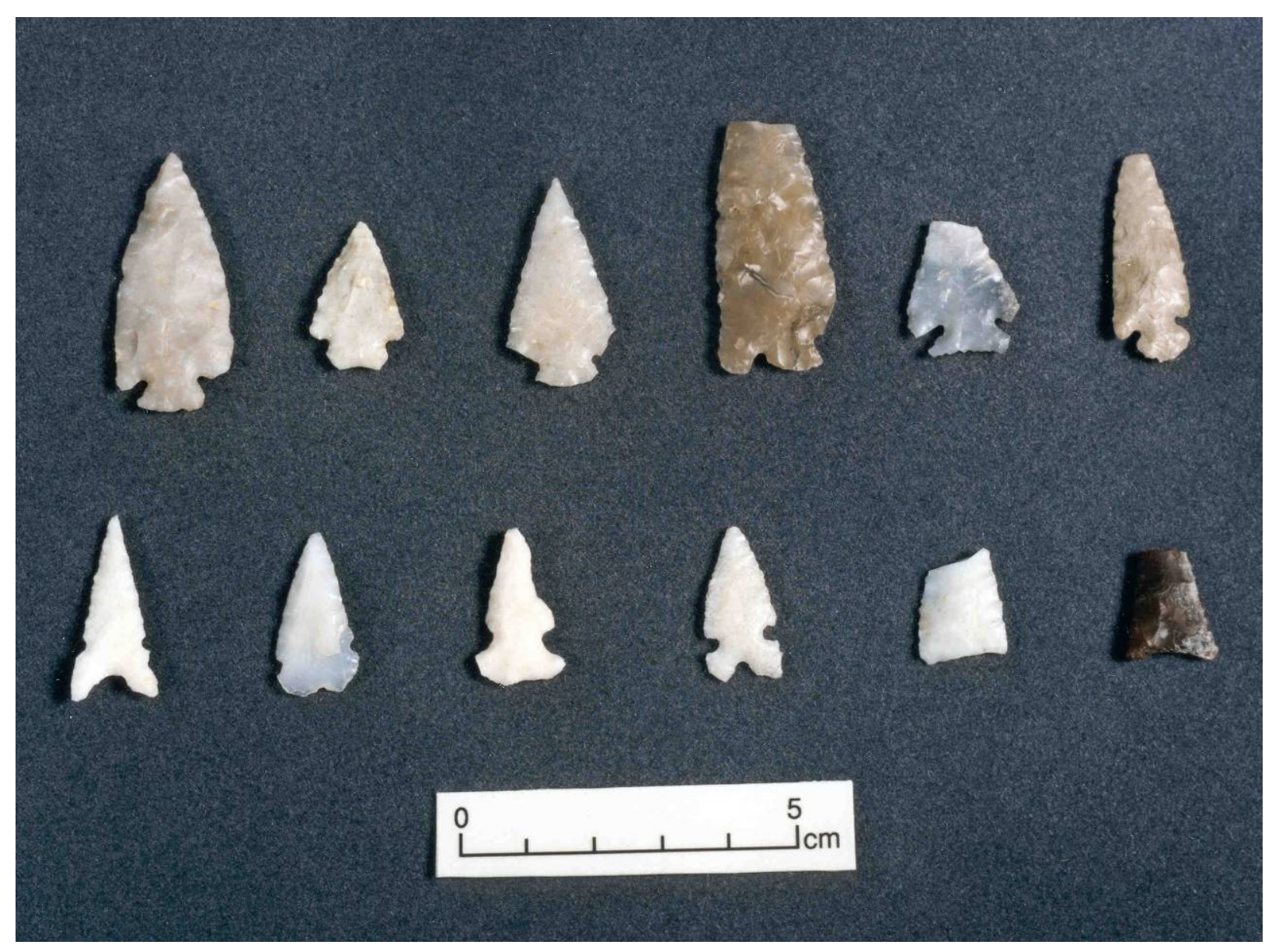

Figure A-21. Prehistoric projectile points from the NTS (photo taken by DRI, 1992) 


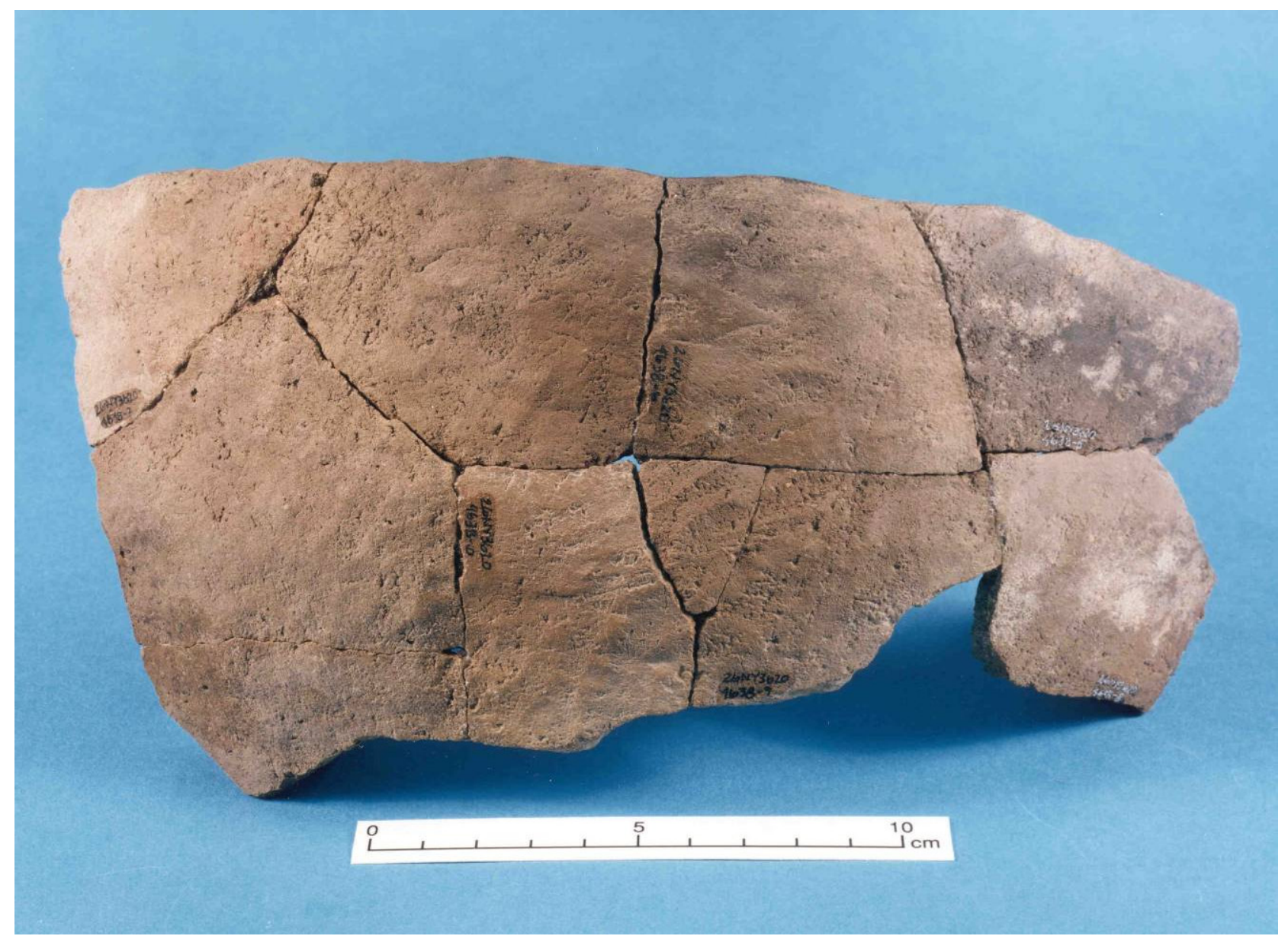

Figure A-22. Brownware bowl recovered from archaeological excavations on Pahute Mesa (photo taken by DRI, 1992)

\section{A.5.6 Ethnohistoric American Indian}

Early explorers and immigrants in the southern Great Basin during the nineteenth century encountered widely scattered groups of Numic-speaking hunters and gatherers currently known as Southern Paiute (see Kelly and Fowler, 1986) and Western Shoshone (see Thomas et al., 1986). The areas traditionally claimed by these tribal entities encompassed a large region and were bound in territories of ethnic or political groups (Stoffle et al., 1990). Subsistence strategies revolved around movements between environmental zones within their territories (e.g., highlands and lowlands), according to the seasonal availability of food resources (Steward, 1938; Wheat, 1967). The normal range was within $32 \mathrm{~km}(20 \mathrm{mi})$ of the primary residential base, but most resources could be found within a short distance of the main camp. Criteria for the location of the primary residential base was nearness to stored or cached foods, availability of water, wood for fuel and house construction, and relatively warm winter temperatures like that found in canyon mouths or in the woodlands (Steward, 1938).

The communal group around Rainier Mesa and the southern end of the Belted Range ca. 1875-880 was known as Eso (little hill) and had an estimated population of 42. This locale is at the boundaries of the traditional tribal lands for the Southern Paiute and Western Shoshone, and the Eso consisted of members from both tribes. The Eso were closely linked linguistically with people to the east, but maintained close relationships with groups all around them, particularly to the north and west. They established winter residential camps at Cane Spring, Captain Jack Spring, Oak Springs, Tippipah Springs (Figure A-23), Topopah Spring, White Rock Springs, and on Pahute and Rainier mesas. Another camp, though not located at a spring, was Ammonia Tanks. 
One of the better known spring sites, Captain Jack Spring, is named after One-eyed Captain Jack, a Paiute who resided there at various times with his wife(s) during the late 1800s and early 1900s (Steward, 1938;

Stoffle et al., 1990). He died in 1928 (Stoffle et al., 1990). At White Rock Springs lived Wandagwana, headman for the Eso. He directed the annual fall rabbit drive in Yucca Flat, which was a time of regional interaction between the various camps and with more distant people. A fandango was usually held at Wungiakuda off the southeast edge of Pahute Mesa (see Johnson et al., 1999) lasting about five days, and provided opportunity for the exchange of goods and information. Sweat houses, also serving as places of integration for the local group, were located at White Rock Springs and at Oak Springs. They were used by both women and men for smoking, gambling, sweating, and as a dormitory.

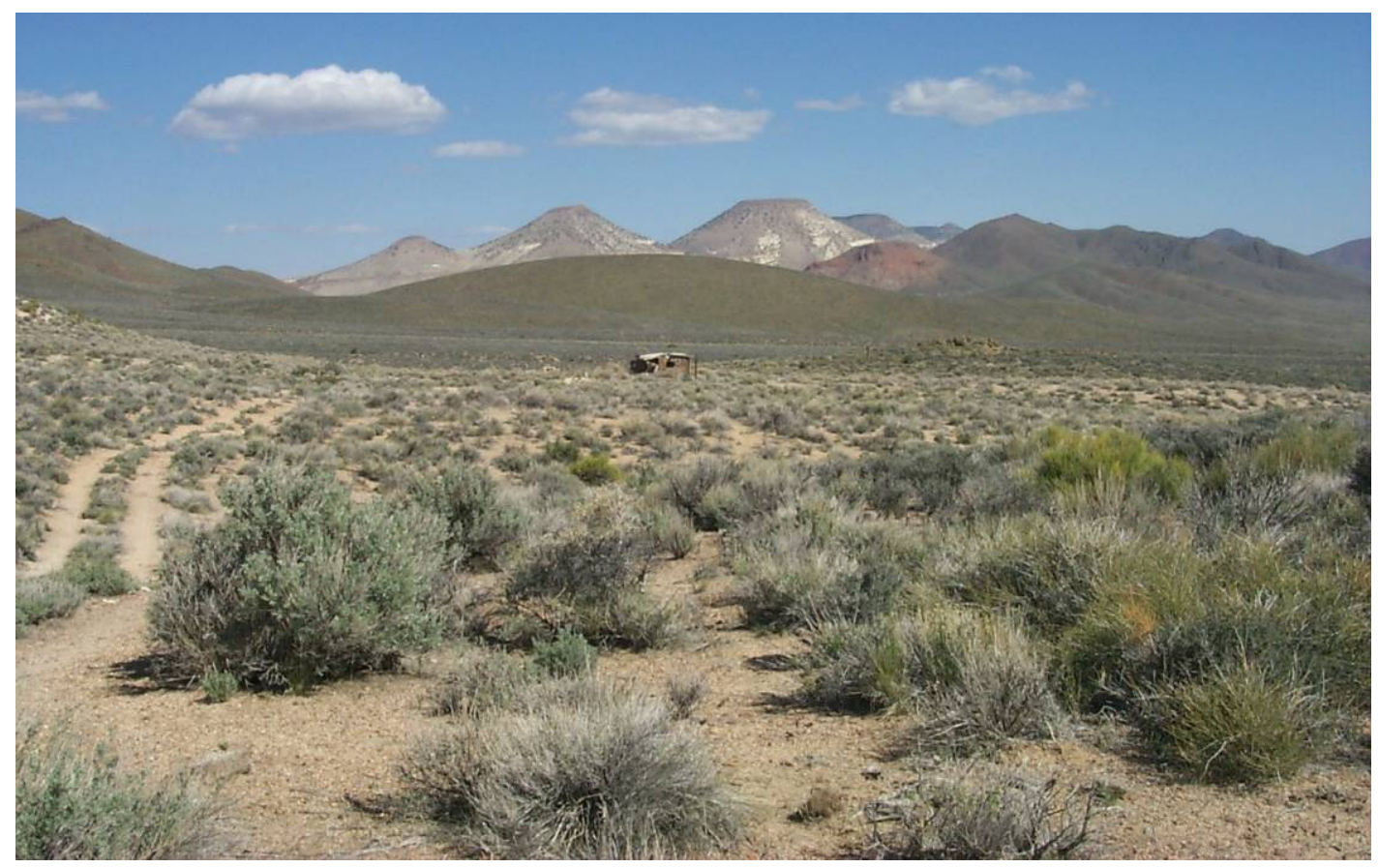

Figure A-23. Overview of the Tippipah Spring area (photo taken by DRI, 2004)

\section{A.5.7 Historic Mining on and near the NTS}

Around the beginning of the twentieth century, when substantial gold and silver deposits were discovered, the Euro American culture began to dominate this particular region of Nevada, with strikes at Tonopah, Goldfield, and Rhyolite (Elliott, 1966; 1973; McCracken, 1992; Zanjani, 1992). The overall population of Nevada doubled (Elliott, 1966; McCracken, 1992). The great mining boom was short-lived, however, and quickly entered the bust phase. By 1908, only four years after it began, mining in the Bullfrog district collapsed and the town of Rhyolite became one of the many ghost towns in the region. For Goldfield, production fell rapidly after 1911 (Zanjani, 1992), but the town still survives today, principally because it is the seat for Esmeralda County (Elliott, 1966). The decline for the Tonopah mining district was more gradual, and the town had time to transform its primary economic base from mining to a supply center, albeit relatively small and limited, for the surrounding ranches, remaining mining districts, and military installations. The Las Vegas and Tonopah rail line lasted until 1918; the rails were removed in 1919 (Myrick, 1963). Still evident on the NTS today are some of the abandoned ties reused for the construction of corrals and other structures at a number of the springs. Around the Beatty area, the ties were used in some of the later mining operations for shoring (McCracken, 1992).

As mining explorations continued in the region, fanning out from the earlier strikes, small mining districts were founded, such as Tolicha in 1917 at the west end of Pahute Mesa (Lincoln, 1923) and the Bare Mountain district just west of the NTS (Cornwall, 1972; Lincoln, 1923; Tingley, 1984). Recorded as an archaeological site by 
Jones et al. (1996), the mining town of Wahmonie in the southern part of the NTS around Mine and Skull mountains was founded in 1928. The history of Wahmonie spans only a few years and was typical of the boomand-bust cycle of the mining industry. The historic mining camp of Wahmonie is located about $10 \mathrm{~km} \mathrm{(6} \mathrm{mi)}$ west of Cane Spring (McLane, 1995; Quade and Tingley, 1984). It grew to a small town with boarding houses, tent stores, and cafes. The Silver Dollar Saloon and the Northern Club were but two of the enterprises (Long, 1950). Most of the miners lived in small tents. George Wingfield, a well-known mine owner and banker in Nevada, became interested and incorporated the Wahmonie Mining Company. Soon, however, the strike was apparently not as rich as had first been thought, and by early 1929 optimism faded and people began leaving Wahmonie. Small amounts of prospecting in the Wahmonie district continued into the 1930s and 1940s, but few ore deposits were ever discovered.

The earliest record of prospecting on what is now the NTS is the Oak Spring mining district centered around the northern edge of Oak Spring Butte (Drollinger, 2002). Documents at the Recorder's Office in Tonopah indicate it was established by the late 1880s. The main objectives of these early mining activities were gold, silver, and chrysocolla, a green to blue mineral resembling turquoise. Lincoln (1923) indicates copper ore containing some silver was shipped in 1917 from the Horseshoe claim in the Oak Spring mining district, and that minor amounts of tungsten were also mined in the district. The Oak Spring district, although having relatively abundant water and wood sources, did not prove to be very productive overall.

B. M. Bower (a.k.a. Bertha Muzzy Sinclair), a noted author, with husband (Bud Cowan) and family, moved to Nevada from Los Angeles, California, in 1920 and took up residence (Figure A-24) at a mining camp near Oak Spring (McLane, 1996) (see Figure A-17). An accomplished and prolific writer, B. M. Bower published a number of short stories and novels over a 40-year career, with some of them becoming the basis for early western-themed movies in Hollywood. She also served as a screenwriter on a couple of them. While living at the camp, Bower wrote 11 novels, incorporating some of the surrounding geographic features, such as Oak Spring Butte and the camp itself, into a few of the stories. (Copies of several of her books have been made electronically available to the public by Project Gutenberg as eText and can be downloaded at:

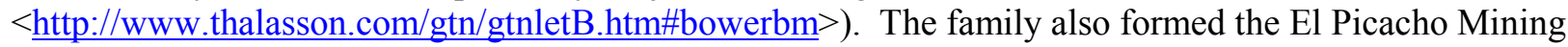
Company, with B. M. Bower serving as the president, and filed assessment work for the claims from 1922 to 1928. The family moved to Las Vegas around 1926, but still worked the mining claims sporadically over the next couple years.

They eventually returned to California. Fittingly, in keeping with the theme for some of the novels, the abandoned camp was used in the early 1930s by outlaws from Utah and Arizona whose escapades were later featured in a Death Valley Days radio episode narrated by Ronald Reagan. B. M. Bower died in 1940 and was inducted into the Western Writers of America Hall of Fame in 1994.

Historically, demand of tungsten for use in weaponry was high during times of war (World Wars I and II, the Korean War) and fell during times of peace (Stager and Tingley, 1988). Correspondingly, so did the mining of tungsten in Nevada. Tungsten was discovered in the Oak Spring district and located at the Climax group in 1937 by V. A. Tamney (Kral, 1951; Stager and Tingley, 1988). Most operations ended when the area was closed with the founding of the bombing and gunnery range by the federal government (Kral, 1951; Quade and Tingley, 1984; Stager and Tingley, 1988). Production was never fully established for these claims, however, and only samples totaling some 15 tons were processed in a nearby dry concentrating mill serving the Oak Spring district. The last known mining operation at the Climax claims was from December 1956 to May 1957 involving a co-use agreement between George Tamney, W. A. Kinney, A. J. Wright, owners of the Climax Tungsten Corporation, and the AEC (McLane, 1996; Quade and Tingley, 1984). The agreement was terminated and no legal mining has since been conducted on the NTS. 


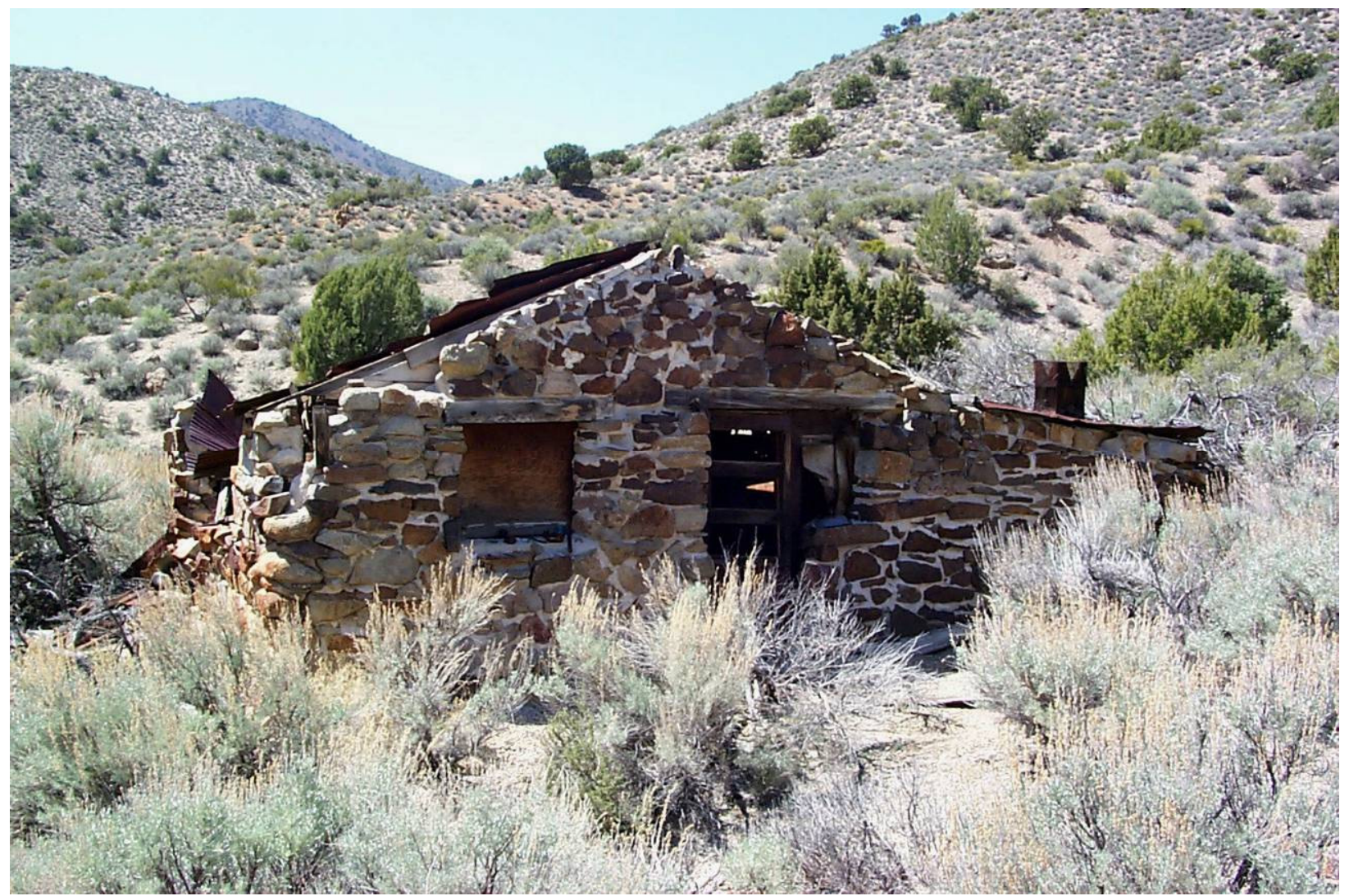

Figure A-24. Bower cabin on the NTS (photo taken by DRI, 2001) 


\section{References}

American Nuclear Society, 2005. American National Standard for Determining Meteorological Information at Nuclear Facilities, ANSI/ANS-3.11-2005, American Nuclear Society, 555 North Kensington Avenue, La Grange Park, IL.

Allen, B. M., S. L. Drellack, Jr., and M. J. Townsend, 1997. Surface Effects of Underground Nuclear Explosions, DOE/NV/11718--122, Bechtel Nevada, Las Vegas, NV.

Antevs, E., 1948. Climatic Changes and Pre White Man, In: The Great Basin with Emphasis on Glacial and Postglacial Times, pp. 168-191, University of Utah Bulletin 38(20), Salt Lake City, UT.

Barnes, H., F. N. Houser, and F. G. Poole, 1963. Geologic Map of the Oak Spring Quadrangle, Nye County, Nevada, U.S. Geological Survey Map GQ-214, scale 1:24,000, Washington, D.C.

Barnes, H., E. B. Ekren, C. L. Rodgers, and D. C. Hedlund, 1982. Geology and Tectonic Maps of the Mercury Quadrangle, Nye and Clark Counties, Nevada, U.S. Geological Survey, Miscellaneous Geologic Investigations Series Map I-1197, scale 1:24,000.

Bath, G. D., C. E. Jahren, J. G. Rosenbaum, and M. J. Baldwin, 1983. Geologic and Geophysical Investigations of Climax Stock Intrusive, Nevada: Magnetic Investigations, U.S. Geological Survey Open-File Report 83377, pp. 40-57, Denver, CO.

Beatley, J. C., 1974. Effects of Rainfall and Temperature on the Distribution and Behavior of Larrea tridentata (creosote-bush) in the Mojave Desert of Nevada, Ecology 55:245-261.

Beatley, J. C., 1975. Climates and Vegetation Pattern Across the Mojave/Great Basin Desert Transition of Southern Nevada, American Midland Naturalist 93:53-70.

Bechtel Nevada, 1998. Ecological Monitoring and Compliance Program Fiscal Year 1998 Report, DOE/NV/11718--255, Las Vegas, NV.

Bechtel Nevada, 1999. Ecological Monitoring and Compliance Program Fiscal Year 1999 Report, DOE/NV/11718--387, Las Vegas, NV.

Bechtel Nevada, 2002a. A Hydrostratigraphic Framework Model of the Pahute Mesa - Oasis Valley Area, Nye County, Nevada, DOE/NV/11718--646, Las Vegas, NV.

Bechtel Nevada, 2002b. A Hydrostratigraphic Model and Alternatives for the Groundwater Flow and Contaminant Transport Model of Corrective Action Units 101 and 102: Central and Western Pahute Mesa, Nye County, Nevada. DOE/NV/11718--706, Las Vegas, NV.

Bechtel Nevada, 2002c. Ecological Monitoring and Compliance Program Fiscal Year 2002, DOE/NV/11718--753, Las Vegas, NV.

Bechtel Nevada, 2003. Nevada Test Site Annual Site Environmental Report for Calendar Year 2002, DOE/NV/11718--842, Las Vegas, NV, prepared for the U.S. Department of Energy, National Nuclear Security Administration Nevada Site Office.

Bechtel Nevada, 2005. A Hydrostratigraphic Framework Model and Alternatives for the Groundwater Flow and Contaminant Transport Model of Corrective Action Unit 98: Frenchman Flat, Clark, Lincoln and Nye Counties, Nevada, DOE/NV/11718--1064, Las Vegas, NV. 
Bechtel Nevada, 2006. A Hydrostratigraphic Model and Alternatives for the Groundwater Flow and Contaminant Transport Model of Corrective Action Unit 97: Yucca Flat-Climax Mine, Lincoln and Nye Counties, Nevada, DOE/NV/11718--1119, Las Vegas, NV.

Blankennagel, R. K., and J. E. Weir, 1973. Geohydrology of the Eastern Part of Pahute Mesa, Nevada Test Site, Nye County, Nevada, U.S. Geological Survey Professional Paper 712-B.

Blout, D. O., D. P. Hammermeister, K. A. Zukosky, and K. D. Donnelson, 1994. Site Characterization Data from the Area 5 Science Boreholes, Nevada Test Site, Nye County, Nevada, Reynolds Electrical \& Engineering Co., Inc., Las Vegas, NV.

BN, see Bechtel Nevada.

Borg, I. Y., R. Stone, H. B. Levy, and C. D. Ramspott, 1976. Information Pertinent to the Migration of Radionuclides in Groundwater at the Nevada Test Site, Part 1: Review and Analysis of Existing Information, UCRL-52078, Part 1, Lawrence Livermore National Laboratory, Livermore, CA.

Bright, D. J., S. A. Watkins, and B. A. Lisle, 2001. Analysis of Water Levels in the Frenchman Flat Area, Nevada Test Site, U.S. Geological Survey Water-Resources Investigations Report 00-4272, Carson City, NV.

Brikowski, T. H., 1991. The Hydrology of Underground Nuclear Tests: The Effect of Collapse-Chimney Formation, Desert Research Institute Publication \#45090, DOE/NV/10845--10, UC-703. Las Vegas, NV.

Byers, F. M., Jr., W. J. Carr, P. P. Orkild, W. D. Quinlivan, and K. A. Sargent, 1976. Volcanic Suites and Related Cauldrons of the Timber Mountain-Oasis Valley Caldera Complex, Southern Nevada, U.S. Geological Survey Professional Paper 919, 70 p. Washington, D.C.

Byers, F. M., Jr., W. J. Carr, and P. P. Orkild, 1989. Volcanic Centers of Southwestern Nevada: Evolution of Understanding, 1960-1988, Journal of Geophysical Research, 94(5):5,908-5,924.

Carle, S. F., M. Zavarin, and G. A. Pawloski, 2008. Spatial Variability of Reactive Mineral and Radionuclide $\mathrm{K}_{\mathrm{d}}$ Distributions in the Tuff Confining Unit: Yucca Flat, Nevada Test Site, LLNL-TR-402227-DRAFT, Lawrence Livermore National Laboratory, Livermore, CA.

Cashman, P. H., and J. H. Trexler, Jr., 1991. The Mississippian Antler Foreland and Continental Margin in Southern Nevada: The Eleana Formation Reinterpreted, In: J. D. Cooper and C. H. Stevens, eds., Paleozoic Paleogeography of the Western United States II, Society of Economic Paleontologists and Mineralogists, Pacific Section, 67:271-280.

Caskey, S. J., and R. A. Schweickert, 1992. Mesozoic Deformation in the Nevada Test Site and Vicinity: Implications for the Structural Framework of the Cordilleran Fold and Thrust Belt and Tertiary Extension North of Las Vegas, Tectonics, 11(6):1,314-1,331.

Chapman, J. B., 1994. Classification of Groundwater at the Nevada Test Site, Desert Research Institute Report 45069, DOE/NV/10384--28, Las Vegas, NV.

Chapman, J. B., and B. F. Lyles, 1993. Groundwater Chemistry at the Nevada Test Site: Data and Preliminary Interpretations, Desert Research Institute Report 45100, DOE/NV/10845--16.

Cole, J. C., 1992. U.S. Geological Survey. Written communication to S. L. Drellack, Raytheon Services Nevada, regarding thickness of Paleozoic units at the Nevada Test Site.

Cole, J. C., 1997. Major Structural Controls on the Distribution of Pre-Tertiary Rocks, Nevada Test Site Vicinity, Southern Nevada, U.S. Geological Survey Open-File Report 97-533. 
Cole, J. C., and P. H. Cashman, 1999. Structural Relationships of Pre-Tertiary Rocks in the Nevada Test Site Region, Southern Nevada, U.S. Geological Survey Professional Paper 1607, U.S. Geological Survey, Denver, CO.

Cornwall, H. R., 1972. Geology and Mineral Deposits of Southern Nye County, Nevada, Bulletin No. 77, Nevada Bureau of Mines and Geology, Mackay School of Mines, University of Nevada, Reno.

D’Agnese, F. A., C. C. Faunt, A. K. Turner, and M. C. Hill, 1997. Hydrogeologic Evaluation and Numerical Simulation of the Death Valley Regional Ground-Water Flow System, Nevada and California, U.S. Geological Survey Water-Resources Investigations Report 96-4300, Denver, CO.

DOE, see U.S. Department of Energy.

DOE/NV, see U.S. Department of Energy, Nevada Operations Office.

Drellack, S. L., L. B. Prothro, K. E. Roberson, B. A. Schier, and E. H. Price, 1997. Analysis of Fractures in Volcanic Cores from Pahute Mesa, Nevada Test Site, DOE/NV/11718--160, Bechtel Nevada, Las Vegas, NV.

Drellack, S. L., and P. H. Thompson, 1990. Selected Stratigraphic Data for Drill Holes in LANL Use Areas of Yucca Flat, NTS, DOE/NV/10322-39, Fenix \& Scisson, Inc., Las Vegas, NV.

DRI, see Desert Research Institute.

Drollinger, H., 2002. An Archaeological Investigation of the Bower Cabin Site, Nevada Test Site, Nye County, Nevada, Cultural Resources Technical Report No. 100, Division of Earth and Ecosystem Sciences, Desert Research Institute, Las Vegas, NV.

Ekren, E. B., C. L. Rogers, R. E. Anderson, and P. P. Orkild, 1968. Age of Basin and Range Normal Faults in Nevada Test Site and Nellis Air Force Range, Nevada, In: Nevada Test Site: The Geological Society of America, Inc., Memoir 110, pp. 247-250.

Elliott, R. R., 1966. Nevada's Twentieth Century Mining Boom: Tonopah, Goldfield, Ely, University of Nevada Press, Reno, NV.

Elliott, R. R., 1973. History of Nevada, University of Nevada Press, Reno, NV.

EPA, see U.S. Environmental Protection Agency.

Faunt, C. C., 1998. Effect of Faulting on Ground-water Movement in the Death Valley Region, Nevada and California, U.S. Geological Survey Report WRI 95-4132, U.S. Geological Survey, Denver, CO.

Fenelon, J. M., 2005. Analysis of Ground-Water Levels and Associated Trends in Yucca Flat, Nevada Test Site, Nye County, Nevada, 1951-2003. U.S. Geological Survey Scientific Investigations Report 2005-5171. Denver, CO.

Fenelon, J. M., 2007. Database of Ground-Water Levels in the Vicinity of Rainier Mesa, Nevada Test Site, Nye County, Nevada, 1957-2005, U.S. Geological Survey Data Series 190, Version 1.10, October 2007, 14 p.

Fenelon, J. M., R. J. Laczniak, and K. J. Halford, 2008. Predevelopment Water-Level Contours for Aquifers in the Rainier Mesa and Shoshone Mountain Area of the Nevada Test Site, Nye County, Nevada, Scientific Investigations Report 2008-5044, 38 p., Las Vegas, NV: U.S. Geological Survey.

Ferguson, J. F., A. H. Cogbill, and R. G. Warren, 1994. A Geophysical-Geological Transect of the Silent Canyon Caldera Complex, Pahute Mesa, Nevada, Journal of Geophysical Research 99(33):4323-4339. 
Fiero, B., 1986. Geology of the Great Basin, University of Nevada Press, Reno, NV, 197 p.

Garber, M. S., 1971. Hydraulic-Test and Quality-of-Water Data from hole U-3cn PS\#2, Bilby Site, Nevada Test Site, U.S. Geological Survey Report USGS-474--102 (NTS-230), Denver, CO.

GeoTrans, Inc., 1995. A Fracture/Porous Media Model of Tritium Transport in Underground Weapons Testing Areas, Nevada Test Site, Boulder, CO.

Gibbons, A. B., E. N. Hinrichs, W. R. Hansen, and R. W. Lemke, 1963. Geology of the Rainier Mesa Quadrangle, Nye County, Nevada, U.S. Geological Survey Map GQ-215, scale 1:24,000, Washington, D.C.

Gillespie, D., J. D. Donithan, and P. R. Seaber, 1996. NTS Water-Supply Wells. DOE/NV/10845-56 (DRI Publication No. 45138), Desert Research Institute, Las Vegas, NV.

Grauch, V. J. S., and M. R. Hudson, 1995. Preliminary Analysis of Major Structures and Lithologic Boundaries for the Frenchman Flat Model Area, U.S. Geological Survey, Denver, CO.

Grayson, D. K., 1993. The Desert's Past: A Natural Prehistory of the Great Basin, Smithsonian Institution Press, Washington, D.C.

Hale, G. S., D. A. Trudeau, and C. S. Savard, 1995. Water-Level Data from Wells and Test Holes Through 1991, and Potentiometric Contours as of 1991 for Yucca Flat, Nevada Test Site, Nye County, Nevada, WaterResources Investigations Report 95-4177, U.S. Geological Survey, Denver, CO.

Hale, W. E., I. J. Winograd, and M. S. Garber, 1963. Preliminary Appraisal of Close-in Aquifer Response to the Bilby Event, Yucca Flat, Nevada, U.S. Geological Survey Technical Letter NTS-63. Denver, CO.

Hansen, D. J., P. D. Greger, C. A. Wills, and W. K. Ostler, 1997. Nevada Test Site Wetlands Assessment, DOE/NV/11718--124, Bechtel Nevada, Las Vegas, NV.

Harrill, J. R., J. S. Gates, and J. M. Thomas, 1988. Major Groundwater Flow Systems in the Great Basin Region of Nevada, Utah, and Adjacent States, Hydrological Investigations Atlas HA-694-C, scale: 1:1,000,000, U.S. Geological Survey, Denver, CO.

Haynes, G. M., 1996. Evaluating Flake Assemblages and Stone Tool Distributions at a Large Western Stemmed Tradition Site near Yucca Mountain, Nye County, Nevada, Journal of California and Great Basin Anthropology 18(1):104-130.

Hershey, R. L., and S. Y. Acheampong, 1997. Estimation of Groundwater Velocities from Yucca Flat to the Amargosa Desert Using Geochemistry and Environmental Isotopes, DOE/NV/11508--26, UC-703 (DRI Publication No. 45157), Desert Research Institute, Las Vegas, NV.

Houser, F. N., and F. G. Poole, 1960. Preliminary Geologic Map of the Climax Stock and Vicinity, Nye County, Nevada, U.S. Geological Survey Map I-328, scale 1:4,800, Washington, D.C.

Hudson, M. R., 1992. Paleomagnetic Data Bearing on the Origin of Arcuate Structures in the French Peak-Massachusetts Mountain Area of Southern Nevada, Geological Society of America Bulletin 104:581-594.

International Technology Corporation, 1996a. Regional Geologic Model Data Documentation Package (Phase I, Data Analysis Documentation, Volume I, Parts 1 and 2), ITLV/10972-181, Las Vegas, NV.

International Technology Corporation, 1996b. Potentiometric Data Task Documentation Package (Phase I, Data Analysis Documentation, Volume II), ITLV/10972-181, Las Vegas, NV. 
International Technology Corporation, 1996c. Hydrologic Parameters Data Documentation Package (Phase I, Data Analysis Documentation, Volume IV), ITLV/10972-181, Las Vegas, NV.

International Technology Corporation, 1997. Groundwater Flow Model Documentation Package (Phase I, Data Analysis Documentation, Volume VI), prepared for the U.S. Department of Energy, Nevada Operations Office, Las Vegas, NV.

International Technology Corporation, 2002. Yucca Flat Hydrogeologic Investigation Wells Drilling and Completion Criteria, ITLV/13052-164. Las Vegas, NV.

IT, see International Technology Corporation.

Jachens, R. C., 1999. Written communication, U.S. Geological Survey, Menlo Park, CA.

Johnson, W. G., R. C. Jones, H. Drollinger, and A. DuBarton, 1999. Archaeological Data Recovery at Site 26NY10133, Nevada Test Site, Nye County, Nevada, Technical Report No. 95, Quaternary Sciences Center, Desert Research Institute, Las Vegas, NV.

Jones R. C., C. M. Beck, A. DuBarton, S. R. Edwards, N. Goldenberg, and J. Carroll, 1996. A Class III Cultural Resources Reconnaissance of the Proposed Reentry Body Impact Fuze Flights (RBIFF), Area 26, Nevada Test Site, Nye County, Nevada, Cultural Resources Reconnaissance Short Report No. SR121395-2, Desert Research Institute, Las Vegas, NV.

Jones, R. C., and S. R. Edwards, 1994. A Clovis Point on the Nevada Test Site, Nevada Archaeologist 12:18-23.

Kelly, I. T., and C. S. Fowler, 1986. Southern Paiute, In: W. L. d'Azevedo, ed., Handbook of North American Indians, Volume 11, Great Basin, pp. 135-148, Smithsonian Institution, Washington, D.C.

Kral, V. E., 1951. Mineral Resources of Nye County, Nevada, Nevada Bureau of Mines and Geology Bulletin 50, 45(3), Mackay School of Mines, University of Nevada, Reno.

Laczniak, R. J., J. C. Cole, D. A. Sawyer, and D. A. Trudeau, 1996. Summary of Hydrogeologic Controls on Ground-Water Flow at the Nevada Test Site, Nye County, Nevada, Water Resources Investigation Report 96-4109, U.S. Geological Survey, Carson City, NV.

Laczniak, R. J., J. L. Smith, P. E. Elliott, G. A. DeMeo, M. A. Chatigny, and G. J. Roemer, 2001. Ground-Water Discharge Determined from Estimates of Evapotranspiration, Death Valley Regional Flow System, Nevada and California, U.S. Geological Survey Water-Resources Investigations Report 01-4195, Carson City, NV.

Lincoln, F. C., 1923. Mining Districts and Mineral Resources of Nevada, Nevada Newsletter Publishing Co., Reno, NV.

Locke, G. L., and R. J. La Camera, 2003. Selected Ground-Water Data for Yucca Mountain Region, Southern Nevada and Eastern California, January 2000-December 2002, U.S. Geological Survey Open-File Report 03-387, Carson City, NV.

Lockett, C. L., and L. C. Pippin, 1990. Re-examining Brownware Ceramics in the Central and Southern Great Basin, in J. M. Mack, ed., Hunter-Gatherer Pottery from the Far West, pp. 67-82, Anthropological Papers No. 23, Nevada State Museum, Carson City, NV.

Long, M., 1950. The Shadow of the Arrow, Caxton Printers, Caldwell, ID.

Lyneis, M, 1982. An Archaeological Element for the Nevada Historic Preservation Plan, Nevada Division of Historic Preservation and Archaeology, Carson City, NV. 
Madsen, D. B., 1982. Get It Where the Gettin's Good: A Variable Model of Great Basin Subsistence and Settlement Based on Data from the Eastern Great Basin, In: D. B. Madsen and J. F. O'Connell, eds., Man and Environment in the Great Basin, pp. 207-226, Society for American Archaeology Paper 2, Washington, D.C.

Madsen, D. B., 1986a. Great Basin Nuts: A Short Treatise on the Distribution, Productivity and Prehistoric Use of Pinyon, In: C. Stout and D. D. Fowler, eds., Anthropology of the Desert West-Essays in Honor of Jesse D. Jennings, pp. 23-41, University of Utah Press, Salt Lake City, UT.

Madsen, D. B., 1986b. Prehistoric Ceramics, In: W. L. d'Azevedo, ed., Handbook of North American Indians, Volume 11, Great Basin, pp. 206-214, Smithsonian Institution, Washington, D.C.

Maldonado, F., 1977. Summary of the Geology and Physical Properties of the Climax Stock, Nevada Test Site, U.S. Geological Survey Open-File Report 77-356, Denver, CO.

McCracken, R. D., 1992. A History of Beatty, Nevada, Nye County Press, Tonopah, NV.

McLane, A. R., 1995. The Silent Land: History of Yucca Mountain and the Fortymile Canyon Country, Nye County, Nevada, Manuscript on file, Quaternary Sciences Center, Desert Research Institute, Reno, NV.

McLane, A. R, 1996. El Picacho, The Writing Cabin of B.M. Bower, Nevada 39(2):134-146.

Mifflin, M. D. and M. M. Wheat, 1979. Pluvial Lakes and Estimated Pluvial Climates of Nevada, Bulletin No. 94, Nevada Bureau of Mines and Geology, Mackay School of Mines, University of Nevada, Reno.

Miller, R. F., and P. E. Wigand, 1994. Holocene Changes in Semiarid Pinyon-Juniper Woodlands, Bioscience 44(7):465-474.

Myrick, D. F., 1963. Railroads of Nevada and Eastern California, Volume 2. Howell-North, Berkeley, CA.

National Security Technologies, LLC, 2007. A Hydrostratigraphic Framework Model and Alternatives for the Groundwater Flow and Contaminant Transport Model of Corrective Action Unit 99: Rainier MesaShoshone Mountain, Nye County, Nevada, DOE/NV/25946--146, Las Vegas, NV.

National Security Technologies, LLC, 2009a. Nevada Test Site Environmental Report 2008, DOE/NV/25946--XXX, Las Vegas, NV, prepared for the U.S. Department of Energy, National Nuclear Security Administration Nevada Site Office.

National Security Technologies, LLC, 2009b. A Hydrostratigraphic System for Modeling Groundwater Flow and Radionuclide Migration at the Corrective Action Unit Scale, Nevada Test Site and Surrounding Areas, Clark, Lincoln, and Nye Counties, Nevada, DOE/NV/25946--630, Las Vegas, NV.

National Security Technologies, LLC, 2009c. Observations on Faults and Associated Permeability Structures in Hydrogeologic Units at the Nevada Test Site, DOE/NV/25946--690, Las Vegas, NV.

NNSA/NSO, see U.S. Department of Energy, National Nuclear Security Administration Nevada Site Office.

NSTec, see National Security Technologies, LLC.

O’Hagan, M. D., and R. J. Laczniak, 1996. Ground-Water Levels Beneath Eastern Pahute Mesa and Vicinity, Nevada Test Site, Nye County, Nevada, U.S. Geological Survey Water-Resources Investigations Report 96-4042, 1 sheet.

Orkild, P. P., 1963. Geologic Map of the Tippipah Spring Quadrangle, Nye County, Nevada, U.S. Geological Survey Map GQ-213, scale 1:24,000, Washington, D.C. 
Orkild, P. P., 1983. Geologic and Geophysical Investigations of Climax Stock Intrusive, Nevada: Summary of Geologic and Geophysical Investigations, U.S. Geological Survey Open-File Report 83-377, pp. 79-82, Denver, CO.

Ostler, W. K., D. J. Hansen, D. C. Anderson, and D. B. Hall, 2000. Classification of Vegetation on the Nevada Test Site. DOE/NV/11718--477, Bechtel Nevada, Ecological Services, Las Vegas, NV.

Pippin, L. C., 1986. An Overview of Cultural Resources on Pahute and Rainier Mesas on the Nevada Test Site, Nye County, Nevada. Desert Research Institute Social Sciences Center, Technical Report No. 45, Desert Research Institute, Reno, NV.

Pippin, L. C., 1998. Hunter-Gatherer Adaptations and Environmental Change in the Southern Great Basin: The Evidence from Pahute and Rainier Mesas, Technical Report No. 92, Quaternary Sciences Center, Desert Research Institute, Reno, NV.

Prothro, L. B., and S. L. Drellack, 1997. Nature and Extent of Lava-Flow Aquifers Beneath Pahute Mesa, Nevada Test Site, Bechtel Nevada, DOE/NV11718--156, Las Vegas, NV.

Quade, J., and J. V. Tingley, 1984. A Mineral Inventory of the Nevada Test Site, and Portions of Nellis Bombing and Gunnery Range, Southern Nye County, Nevada, Open File Report 84-2, Nevada Bureau of Mines and Geology, University of Nevada, Reno.

Randerson, D., 1997. Analysis of Extreme Precipitation Events in Southern Nevada, NOAA Technical Memorandum ERL ARL-221, Air Resources Laboratory, Silver Spring, MD.

Randerson, D., and J. B. Sanders, 2002. Characterization of Cloud-to-Ground Lightning on the Nevada Test Site, NOAA Technical Memorandum OAR ARL-242, Air Resources Laboratory, Silver Spring, MD.

Reiner, S. R., G. L. Locke, and L. S. Robie, 1995. Ground-Water Data for the Nevada Test Site and Selected Other Areas in South-Central Nevada, 1992-1993, U.S. Geological Survey Open-File Report 95-160, Las Vegas, NV.

Reno, R. L., 1985. Clovis Projectile Points from Lahontan Reservoir and the Nevada Test Site, Nevada, Nevada Archaeologist 5(1):7-9.

Reno, R. L., G. H. Henton, L. C. Pippin, and C. L. Lockett, 1989. Miscellaneous Data Recovery Studies at Yucca Mountain. Technical Report No. 59, Desert Research Institute, Reno, NV.

Rhode, D., 1994. Direct Dating of Brown Ware Ceramics using Thermoluminescence and Its Relation to the Numic Spread, In: D. B. Madsen and D. Rhode, eds., Across the West: Human Population Movement and the Expansion of the Numa, pp. 124-130, University of Utah Press, Salt Lake City, UT.

Robie, L. S., G. L. Locke, and S. R. Reiner, 1995. Ground-Water Data for the Nevada Test Site, 1992, and for Selected Other Areas in South-Central Nevada, 1952-1992, U.S. Geological Survey Open-File Report 95-284.

Rose, T. P., J. M. Kenneally, D. K. Smith, M. L. Davison, G. B. Hudson, and J. H. Rego, 1997. Chemical and Isotopic Data for Groundwater in Southern Nevada, Lawrence Livermore National Laboratory Report UCRL-ID-128000, Livermore, CA.

Sawyer, D. A., R. J. Fleck, M. A. Lanphere, R. G. Warren, and D. E. Broxton, 1994. Episodic Caldera Volcanism in the Miocene Southwest Nevada Volcanic Field: Revised Stratigraphic Caldera Framework, ${ }^{40} \mathrm{Ar} /{ }^{39} \mathrm{Ar}$ Geochronology and Implications for Magnetism and Extension, Geological Society of America Bulletin 67(10):1304-1318. 
Shutler, R. Jr., 1961. Lost City, Pueblo Grande de Nevada, Anthropological Papers No. 5, Nevada State Museum, Carson City, NV.

Slate, J. L., M. E. Berry, P. D., Rowley, C. J. Fridrich, K. S. Morgan, J. B. Workman, O. D. Young, G. L. Dixon, V. S. Williams, E. H. McKee, D. A. Ponce, T. G. Hildenbrand, W. C. Swadley, S. C. Lundstrom, E. B. Ekren, R. G. Warren, J. C. Cole, R. J. Fleck, M. A. Lanphere, D. A. Sawyer, S. A. Minor, D. J. Grunwald, R. J. Laczniak, C. M. Menges, J. C. Yount, and A. S. Jayko, 1999. Digital Geologic Map of the Nevada Test Site and Vicinity, Nye, Lincoln, and Clark Counties, Nevada, and Inyo County, California, U.S. Geological Survey Open-File Report 99B554BA.

SNJV, see Stoller-Navarro Joint Venture.

Snyder, R. P., 1977. Geology of the Gold Meadows Stock, Nevada Test Site, U.S. Geological Survey Report 474-179, Denver, CO.

Stager, H. K., and J. V. Tingley, 1988. Tungsten Deposits in Nevada, Bulletin No. 105, Nevada Bureau of Mines and Geology, Reno, NV.

State of Nevada Engineers Office, 1974. Static Groundwater Levels of Nevada. Division of Water Resources, State Engineers Office, Carson City, NV.

Steward, Julian H., 1938. Basin-Plateau Aboriginal Sociopolitical Groups, Bureau of American Ethnology Bulletin 120, Smithsonian Institution, Washington, D.C. Reprinted by University of Utah Press, Salt Lake City, 1997.

Stoffle, R. W., D. B. Halmo, J. E. Olmsted, and M. J. Evans, 1990. Native American Cultural Resource Studies at Yucca Mountain, Nevada, Institute for Social Research, The University of Michigan, Ann Arbor.

Stoller-Navarro Joint Venture, 2004a. Phase II Hydrologic Data for the Groundwater Flow and Contaminant Transport Model of Corrective Action Unit 98: Frenchman Flat, Nye County, Nevada. S-N/99205-032, Rev. 0, Las Vegas, NV.

Stoller-Navarro Joint Venture, 2004b. Hydrologic Data for the Groundwater Flow and Contamination Transport Model of CAU Units 101 and 102: Central and Western Pahute Mesa, Nye County, Nevada, S-N/99205002, Shaw/13052-204, Rev. 0, Las Vegas, NV.

Stoller-Navarro Joint Venture, 2006a. Phase II Groundwater Flow Model of Corrective Action Unit 98: Frenchman Flat, Nye County, Nevada, S-N/99205--074, Las Vegas, NV.

Stoller-Navarro Joint Venture, 2006b. Phase I Hydrologic Data for Corrective Action Unit 97: Yucca Flat-Climax Mine, Lincoln and Nye County, Nevada. S-N/99205--077, Las Vegas, NV.

Stoller-Navarro Joint Venture, 2006c. Groundwater Flow Model of Corrective Action Units 101 and 102: Central and Western Pahute Mesa, Nevada Test Site, Nye County, Nevada, S N/99205--076, Rev. 0, Las Vegas, NV.

Stoller-Navarro Joint Venture, 2007. An Addendum to the Phase II Groundwater Flow Model of Corrective Action Unit 98: Frenchman Flat, Nevada Test Site, Nye County, Nevada, S-N/99205--074, Las Vegas, $\mathrm{NV}$.

Stoller-Navarro Joint Venture, 2009. Phase I Transport Model of Corrective Action Units 101 and 102: Central and Western Pahute Mesa, Nevada Test Site, Nye County, Nevada, S N/99205--111, Rev. 1, Las Vegas, $\mathrm{NV}$. 
Thomas, D. H., L. S. A. Pendleton, and S. C. Cappannari, 1986. Western Shoshone, in W. L. d'Azevedo, ed., Handbook of North American Indians, Volume 11, Great Basin, pp. 262-283, Smithsonian Institution, Washington, D.C.

Tingley, J. V., 1984. Trace Element Associations in Mineral Deposits, Bare Mountain (Flourine) Mining District, Southern Nye County, Nevada, Report No. 39, Nevada Bureau of Mines and Geology, Reno, NV.

Trexler, J. H., Jr., J. C. Cole, and P. H. Cashman, 1996. Middle Devonian-Mississippian Stratigraphy on and near the Nevada Test Site: Implications for Hydrocarbon Potential, American Association of Petroleum Geologists Bulletin 80(11):1736-1762, Tulsa, OK.

Trexler, J. H., Jr., P. H. Cashman, J. C. Cole, W. S. Snyder, R. M. Tosdal, and V. I. Davydov, 2003. Widespread Effects of Middle Mississippian Deformation in the Great Basin of Western North America, Geological Society of America Bulletin, Vol. 115, No. 10, pp. 1278-1288.

Tuohy, D. R., 1965. Stone Age Missiles from a Modern Test Site, Masterkey 39(2):44-59.

U.S. Department of Energy, 1996. Final Environmental Impact Statement for the Nevada Test Site and Off-Site Locations in the State of Nevada, Volume 1, Chapters 1-9, DOE/EIS--0243, Las Vegas, NV.

U.S. Department of Energy, National Nuclear Security Administration Nevada Site Office, 2006a. Completion Report for Well ER-12-4. Corrective Action Unit 99: Rainier Mesa-Shoshone Mountain, DOE/NV--1128, Las Vegas, NV.

U.S. Department of Energy, National Nuclear Security Administration Nevada Site Office, 2006b. Completion Report for Well ER-16-1. Corrective Action Unit 99: Rainier Mesa-Shoshone Mountain, DOE/NV--1180, Las Vegas, NV.

U.S. Department of Energy, National Nuclear Security Administration Nevada Site Office, 2006c. Completion Report for Well ER-12-3, Corrective Action Unit 99: Rainier Mesa-Shoshone Mountain, DOE/NV/11718--1182, Bechtel Nevada, Las Vegas, NV.

U.S. Department of Energy, Nevada Operations Office, 1997. Regional Groundwater Flow and Tritium Transport Modeling and Risk Assessment of the Underground Test Area, Nevada Test Site, Nevada, DOE/NV--477, Las Vegas, NV.

U.S. Department of Energy, Nevada Operations Office, 1999. Corrective Action Investigation Plan for Corrective Action Units 101 and 102: Central and Western Pahute Mesa, Nevada Test Site, Nevada, DOE/NV--516, Las Vegas, NV.

U.S. Department of Energy, Nevada Operations Office, 2000. United States Nuclear Tests, July 1945 through September 1992, DOE/NV--209 (Rev. 15), Las Vegas, NV.

U.S. Environmental Protection Agency, 2000. On-Site Meteorological Program Guidance for Regulatory Modeling Applications, EPA-450/4-87 013, Office of Air Quality Planning and Standards, Research Triangle Park, NC.

Waddell, R. K., J. H. Tobison, and R. K. Blankennagel, 1984. Hydrology of Yucca Mountain and Vicinity, Nevada-California Investigative Results through Mid-1983, U.S. Geological Survey Water-Resources Investigation Report 84-4267, Denver, CO.

Walker, G. E., 1962. Groundwater in the Climax Stock, Nevada Test Site, Nye County, Nevada, U.S. Geological Survey Trace Element Investigations Report TEI-813, Washington, D.C. 
Warren, C. N., and R. H. Crabtree, 1986. Prehistory of the Southwestern Area, In: W. L. d'Azevedo, ed., Handbook of North American Indians, Volume 11, Great Basin, pp. 183-193, Smithsonian Institution, Washington, D.C.

Warren, R. G., G. L. Cole, and D. Walther, 2000a. A Structural Block Model for the Three-Dimensional Geology of the Southwestern Nevada Volcanic Field, Los Alamos National Laboratory Report LA-UR-00-5866.

Warren, R. G., D. A. Sawyer, F. M. Byers, Jr., and J. C. Cole, 2000b. A Petrographic/Geochemical Database and Stratigraphic and Structural Framework for the Southwestern Nevada Volcanic Field, Internet address: $<$ http://www.pggdb-swnvf.lanl.gov/>, as accessed on September 20, 2004, LANL Report LA-UR-00-3791.

Warren, R. G., D. A. Sawyer, F. M. Byers, Jr., and J. C. Cole, 2003. A Petrographic/Geochemical and Geophysical Database, and Stratigraphic Framework for the Southwestern Nevada Volcanic Field, LANL Report LA-UR-03-1503.

Wheat, M. M., 1967. Survival Arts of the Primitive Paiutes, University of Nevada Press, Reno.

Wills, C. A., and W. K. Ostler, 2001. Ecology of the Nevada Test Site: An Annotated Bibliography, with Narrative Summary, Keyword Index, and Species List, DOE/NV/11718--594, Bechtel Nevada, Ecological Services, Las Vegas, NV.

Winograd, I. J., and W. Thordarson, 1975. Hydrogeologic and Hydrochemical Framework South-Central Great Basin, Nevada-California, with Special Reference to the Nevada Test Site, U.S. Geological Survey Professional Paper 712-c, U.S. Government Printing Office, Washington, D.C.

Winslow, D. L., 1996. Restricted Reconnaissance: Wheeler's Nye County Explorations, M.A. thesis, Department of Anthropology, University of Nevada, Las Vegas.

Worman, F. C. V., 1965. Anatomy of the Nevada Test Site, University of California Los Alamos Scientific Laboratory Report, Los Alamos, NM.

Worman, F. C. V., 1966. The Current Status of Archaeology at the Nevada Test Site and the Nuclear Rocket Development Station, University of California Los Alamos Scientific Laboratory, General, Miscellaneous and Progress Reports LA-3250-MS, U.S.A.E.C. Contract W-7405-Eng-36, Los Alamos, NM.

Worman, F. C. V., 1967. Nevada Test Site Archaeology, Nevada Archaeological Survey Reporter 1(2):5-6.

Worman, F. C. V., 1969. Archaeological Investigations at the U.S. Atomic Energy Commission's Nevada Test Site and Nuclear Rocket Development Station, Report LA4125, University of California Los Alamos Scientific Laboratory, Los Alamos, NM.

Zanjani, S., 1992. Goldfield: The Last Gold Rush on the Western Frontier, Ohio University Press, Athens. 



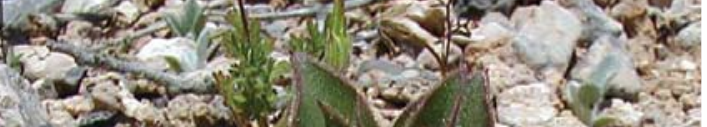
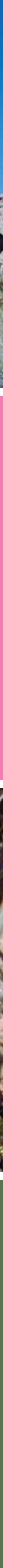